| 02 ENCUESTA 05/06/2012 7:28 Página 9

ENCUESTA 
02 ENCUESTA 05/06/2012 7:28 Página 10 


\title{
ENCUESTA SOBRE \\ LA REFORMA DE LA CONSTITUCIÓN
}

\author{
PRESENTACIÓN
}

En estos párrafos, a modo de pequeño pórtico de nuestra encuesta, debemos empezar por confesar al lector que la misma y todo el presente número monográfico se concibió por nuestro equipo de dirección y redacción en mayo-junio de 2011, cuando nada sabíamos de que en pleno verano se iba a abordar la reforma del constitucionalismo económico de nuestra Carta Magna de 1978.

De manera que acometimos la redacción de las preguntas sin contemplar la posibilidad de que nuestra modesta encuesta se cruzase en el camino de una veloz reforma que tendría fecha de 2011. Y habíamos rogado a una serie de catedráticos de la asignatura que aceptasen contestar el cuestionario sin plantearnos su proximidad hacia la problemática del Título VII de nuestra Lex Normarum.

Pero a la vuelta del verano éramos naturalmente conscientes, de un lado, de que nuestros colegas habían empezado a escribir sobre las preguntas que les habíamos remitido y, de otro, que era preciso incluir al menos dos preguntas sobre el contenido dispositivo de la reforma del Artículo 135 CE y sobre la forma en que la misma se había afrontado y tramitado.

Ésta es, por tanto, la primera vez en la historia de esta revista en que ha habido que corregir sobre la marcha el cuestionario de esta sección, por lo que hemos de pedir públicamente disculpas a los catedráticos que en principio aceptaron contestarnos y después reconsideraron hacerlo y a los que finalmente han respondido. También presentamos nuestras excusas a los lectores que entiendan que el resultado no está a la altura de sus expectativas.

Por supuesto toda la responsabilidad la asume el director de esta publicación, pues sabido es que siendo el poder constituyente soberano...

Lo que nuestra revista no haya podido en esta ocasión aportar a través de esta encuesta que sirve de apertura al presente número monográfico, lo ha procurado colmar en otras secciones del presente número, mediante encargos de trabajos que estudian, en unos casos, los antecedentes recientes que en el Derecho Comparado occidental tiene la reforma constitucional española de 2011, y, en otros, nuestra reforma patria desde diversos ángulos.

Queriendo Teoría y Realidad Constitucional expresar públicamente su más sincera gratitud a cuantos profesores de la disciplina han accedido con premura a nuestros requerimientos de colaborar en este número monográfico, en que nos hemos encontrado una vez 
más con que la dura realidad económica y los excesos en el ejercicio del poder político han demandado nuevas formas de control jurídico constitucional del poder de los legisladores estatales o autonómicos e incluso de la capacidad de gasto de los ayuntamientos. Ello obviamente ha sucedido una vez que España asumió la limitación de soberanía que supuso sustituir su moneda tradicional, la peseta, por el euro, en un contexto de pertenencia a una Unión Europea carente de política económica unificada, pero consciente de que tiene que avanzar en el proceso de su institucionalización. Y emitiendo nuestra nación deuda soberana en demasía, que es tanto como decir que trasmitiendo soberanía a los acreedores. Parece que finalmente la principal potencia europea ha concluido que el control de la potestad de presupuestar, gastar y emitir deuda por las Cámaras se ha de limitar en las constituciones de los Estados miembros, correspondiendo a los respectivos tribunales constitucionales enjuiciar las contravenciones que se produzcan respecto de los nuevos parámetros jurídico constitucionales sobre el gasto público y la deuda. Todo un horizonte para el trabajo de los constitucionalistas europeos y de otras latitudes.

Dejamos apuntado, como se ve, que esta revista es bien consciente de que no agota con este número monográfico tan importante temática, quedando sus páginas abiertas para cuantas colaboraciones rigurosas nos lleguen al respecto desde los enfoques que libremente quieran adoptar los especialistas en nuestra rama del Derecho.

Dado el tema de esta encuesta, y de modo excepcional, se ha considerado oportuno pedir también la opinión de un autor alemán que, como Paul Kirchhof, catedrático emérito de Derecho Público, Financiero y Presupuestario en la Universidad de Heidelberg y antiguo Magistrado del Tribunal Constitucional alemán, pudiera ofrecer su criterio, fundado en el conocimiento profundo del Derecho constitucional y presupuestario del Estado que ha liderado en la Unión Europea los movimientos tendentes a constitucionalizar el principio de estabilidad presupuestaria. A tales efectos, sin embargo, era imprescindible cierta adaptación de las cuestiones; Antonio López Pina ha asumido generosamente la doble tarea de formular las preguntas y traducir las respuestas.

\section{CUESTIONES}

1. Sabido es que hasta el verano de 2011 nuestra Constitución de 1978 llevaba más de treinta años sin ser reformada (con la puntual excepción, por imperativo del Tratado de Maastricht, de dos palabras del art.13.2 (E). Esta larga petrificación ¿Qué valoración global le merece?

2. ¿Querría adelantarnos su opinión sobre el Título X que rige «la reforma constitucional»? Es decir, ¿Sería favorable a abordar la reforma de algún punto de nuestro sistema de reforma de la Constitución? Y, más en concreto, ¿Piensa que la no actualización de la CE se debe a la dificultad de alcanzar acuerdos magnos entre los partidos políticos españoles o a otras causas?, ¿Qué opinión le merece el proceso dotado de especial rigidez recogido en el art. 168? Y ¿Cree Vd. bien definidos en el mismo artículo los ámbitos de la Constitución sujetos a esta vía agravada o, por el contrario, incluiría alguno más, o exceptuaría preceptos constitucionales actualmente sólo modificables por esta vía dificultativa de su reforma?

3. Qué opina Vd. sobre el camino procedimental que siguió el primer Gobierno del Sr. Rodríguez Zapatero para instar ciertas reformas constitucionales? ¿Qué otra forma de preparar la reforma en términos politicos y técnico jurídicos le bubiera parecido más positiva? $Y$ ¿Entiende Vd. 
que las prioridades de actualización de nuestra Constitución coincidian con las que aquel Gobierno sometió al informe del Consejo de Estado?

4. ¿Nos puede dar su opinión sobre los aspectos de las partes dogmática y orgánica de la CE cuya reforma considera más importante o urgente, sin perjuicio de poder extenderse más adelante en las materias referidas en las tres preguntas siguientes?

5. ¿Aconsejaría abordar la reforma de la composición (incluido, si así lo estima conveniente, el sistema electoral) del Congreso y del Senado? ¿Y de sus funciones básicas?

6. ¿Qué nos quiere decir sobre la pertinencia y posibilidad de reformar el Título VIII —organización local y autonómica - y sobre las orientaciones que debieran presidir, en su caso, la reforma?

7. A la luz de la reciente reforma del artículo 135 del texto constitucional, ¿podría realizar una valoración sobre su pertinencia, sobre el contenido sustantivo y sobre la literalidad de la misma?

8. ¿Podría realizar también una valoración sobre el procedimiento que se ha seguido en esta última reforma de nuestra Carta Magna y que, aun cumpliendo las previsiones del art. 167 CE, ha sido objeto de numerosas críticas?

\section{ENCUESTADOS}

MANUEL CONTRERAS CASADO, Catedrático de Derecho Constitucional de la Universidad de Zaragoza

ELOY GARCÍA LÓPEZ, Catedrático de Derecho Constitucional de la Universidad de Vigo

JUAN CARLOS GAVARA DE CARA, Catedrático de Derecho Constitucional de la Universidad de Barcelona

ALBERTO LÓPEZ BASAGUREN, Catedrático de Derecho Constitucional de la Universidad del País Vasco

ANTONIO LÓPEZ PINA, Catedrático de Derecho Constitucional de la Universidad Complutense de Madrid

\section{RESPUESTAS}

1. Sabido es que hasta el verano de 2011 nuestra Constitución de 1978 llevaba más de treinta años sin ser reformada (con la puntual excepción, por imperativo del Tratado de Maastricht, de dos palabras del art.13.2 CE). Esta larga petrificación ¿Qué valoración global le merece?

\section{MANUEL CONTRERAS CASADO}

Acogiéndome a la benevolencia de esta Revista me permito unir en una sola, y desordenada, respuesta mi opinión sobre las diversas cuestiones planteadas.

Reformar la Constitución exige una previa decisión política, y esa decisión le corresponde a las fuerzas políticas dominantes en el momento en que la necesidad de 
cambio se haga presente. Si olvidamos esta cuestión difícilmente entenderemos las dificultades que hasta hoy han imposibilitado la reforma de la CE.

De entrada, que una Constitución haya durado más de treinta años sin cambios significativos puede ser una excelente noticia de buena salud constitucional, o un preocupante indicio de esclerotización progresiva. Por mi parte, sin olvidar que una Constitución no expresa nunca un ideal de justicia, me inclinaría por pensar que, respetando los pilares básicos del texto constitucional que me parecen todavía plenamente vigentes, sería conveniente una limitada revisión del mismo.

De hecho, hubiera sido conveniente reformar la CE en un aspecto esencial, la configuración de nuestro Estado de las autonomías, antes de que se produjera la última oleada de reformas estatutarias a comienzos del presente siglo. En aquellos momentos, algunas voces expresaron la sensata opinión de que antes de acometer una generalizada reforma de las normas estatutarias como la que se estaba llevando a cabo, hubiera sido preferible emprender una reforma de la Constitución que acomodara las normas constitucionales a la realidad del Estado autonómico 25 años después del inicio de su construcción. A estas alturas, parece evidente que ya solo cabe lamentarse de que no fuera posible tal reforma. La cuestión es ¿por qué no fue viable entonces el cambio de nuestra norma fundamental?.

Y creo que la clave de por qué no fue posible se puede hallar atendiendo al Informe del Consejo de Estado sobre las propuestas de reforma constitucional planteadas en aquel entonces por el Gobierno de la Nación, que en sus páginas introductorias señalaba con sensatez cómo el acierto en los procesos de revisión constitucional depende de la conjunción de varios factores, a saber: «a) que los cambios a introducir respondan a demandas consistentes y que busquen resolver problemas o insuficiencias ampliamente reconocidas; b) que sean limitados y prudentes para no alterar el equilibrio en el que se sustenta el texto constitucional; c) que las alternativas propuestas hayan sido suficientemente maduradas y sean consecuencia de un diálogo sostenido y sereno entre las fuerzas políticas y con la sociedad; d) que se genere en torno a las modificaciones un consenso asimilable al que concitó el texto que se quiere reformar; y, en fin, como no puede ser de otro modo, es condición imprescindible que las reformas se lleven a cabo respetando escrupulosamente los mecanismos establecidos en la Constitución, pues el respeto a las reglas y a los procedimientos prefigurados forma parte de la esencia misma de la democracia» (El Informe del Consejo de Estado sobre la reforma constitucional. Texto del informe y debates académicos, Francisco Rubio Llorente y José Álvarez Junco (coords.), Consejo de Estado-Centro de Estudios Políticos y Constitucionales, Madrid, 2006).

Apliquemos ahora estos criterios sobre la realidad española del momento y llegaremos con facilidad a las siguientes conclusiones: se cumplían seguramente los dos primeros, puesto que había una cierta demanda que sin duda buscaba remediar algunas insuficiencias constitucionales, y, hasta donde conozco, los cambios que se proponían eran limitados y prudentes, sin pretender poner cabeza abajo el texto constitucional; pero no sucede lo mismo con los otros factores, pues, independientemente de que las alternativas hubieran sido o no suficientemente maduradas, era evidente que no habían sido fruto de un diálogo sostenido y sereno entre las fuerzas políticas y entre éstas y la sociedad, ni tampoco se había generado un consenso suficiente, ni lejanamente parecido al consenso constitucional, en torno a las propuestas de reforma conocidas. 
Pero claro, dicho esto realmente no hemos respondido a la interrogante planteada inicialmente, más bien la hemos sustituido por otra que la continúa, a saber, por qué no podíamos contar con que se cumplieran estos dos factores necesarios para realizar una reforma constitucional de este tipo. Y la respuesta enlaza directamente con otra cuestión: cómo después de acudir en dos ocasiones al pacto estatal entre los grandes partidos realmente el único acuerdo que haría posible la reforma constitucional o una reforma ordenada de los Estatutos (o ambas cosas sucesivamente)_, nos encontrábamos entonces con la imposibilidad manifiesta, y no solo por razones políticamente coyunturales harto conocidas (la ausencia total de consonancia entre las dos grandes fuerzas políticas estatales), de hallar un punto de encuentro. Y la respuesta posiblemente era que reeditar en aquel momento un pacto autonómico por la reforma implicaba un grado de complejidad que antes no existía, y que derivaba básicamente de algunas motivaciones concatenadas: la primera de ellas era el nivel de desarrollo que habían alcanzado ya las Comunidades Autónomas; y la segunda, consecuentemente, era la relativa autonomía política de estas Comunidades con respecto a los grandes partidos y su capacidad de decisión a partir de intereses políticos propios.

En suma, esto es simplemente un ejemplo de cómo en un momento determinado de nuestro desarrollo constitucional hubiera sido conveniente abordar la reforma de la CE. Lo que no significa que a día de hoy haya desaparecido esa misma necesidad, en cuanto al Estado de las autonomías se refiere.

El problema es que hace tiempo que nos hemos habituado a contemplar cómo la opinión publica recibe regularmente las más variadas propuestas de reforma sobre la Constitución española de 1978, y no solo cuando se acerca la fecha de su aniversario. De todas ellas, quizá la más recurrente sea la que tiene como objetivo el Senado, esa Cámara que algunos perciben como una incomodidad y otros como una esperanza, porque o bien no se sabe muy bien qué hacer con ella (seguramente a consecuencia de una cierta mala conciencia de mantenerla como un lujo prescindible), o bien se confía en transformarla en esa Cámara territorial que proclama la Constitución (claro, no en mismos los términos del propio texto constitucional) y que al parecer nos acercaría a una forma más federalizada de Estado. A estas alturas, no obstante, ya tenemos la certeza de la lejanía en que se ha situado la reforma del Senado, al menos desde la perspectiva constitucional. Tan lejana es esa posibilidad que seguramente ya serán pocos los interesados en que tal evento suceda: al contrario, ha aumentado considerablemente el número de quienes sencillamente contemplan ya sólo la drástica solución de suprimir el Senado. Es lo que suele suceder cuando el esfuerzo inútil desemboca en la melancolía y el desaliento.

Hay quien centra las dificultades de la reforma constitucional en las características de los procedimientos articulados en el Título X de la CE, y en consecuencia plantea la necesidad de reformar la propia reforma. Ahora bien, ¿conviene plantearse la necesidad de realizar semejante operación?. Porque una cosa es evidenciar los defectos del Título X, que sin duda los tiene, y otra muy distinta estar en posesión de soluciones claras a sus precariedades.

Pues bien, a mi modo de ver no es realmente necesario reformar la reforma. Desde una cierta variedad de posibilidades procedimentales, el legislador constituyente optó por unos mecanismos que pueden ser, y lo han sido, objeto de crítica, pero que no obstaculizan seriamente la eventual actividad del poder de revisión. A las pruebas me remito: 
cuando ha sido necesario reformar el texto constitucional se ha hecho sin grandes dificultades (incluso, como es conocido, vía «urgencia estival», aunque tengo serias dudas sobre la «necesidad» de la modificación perpetrada en el último verano). Por eso coincido en este punto con quienes afirman que los problemas de un planteamiento reformista sobre la Constitución española hay que buscarlos fuera del Título X. Estoy convencido de que es sumamente conveniente hablar de la reforma constitucional, criticar y polemizar sobre el Título X, sobre la in/exclusión de la iniciativa legislativa popular, lo intransitable del procedimiento del art. $168 \mathrm{CE}$ o la in/conveniencia de las cláusulas de intangibilidad, pero son las condiciones políticas en que se plantee, llegado el caso, una reforma constitucional, y las tensiones bajo las que se desarrolle en su momento tal proceso, las que pondrán al descubierto la verdadera medida del acierto de los constituyentes de 1978 en esta cuestión. En última instancia, y vuelvo a mi afirmación inicial, se trata de una decisión política que corresponderá en su momento a las fuerzas políticas mayoritarias. Y si no fuera mucho pedir a los partidos politicos, sería deseable, cuando algún día esto suceda, que la reforma de nuestra Constitución fuera llevada a cabo de forma más seria y meditada, desde el punto de vista participativo y procedimental, que la última «urgencia estival» que modificó nuestra Constitución por segunda vez.

\section{ELOY GARCÍA LÓPEZ}

Entiendo que la «petrificación» de la Constitución, que como hecho político es un fenómeno que va bastante más allá de la inoperancia de los mecanismos de reforma, no puede ser enjuiciada al margen de la noción y del concepto de Constitución de los que deriva y de la praxis constitucional que se ha venido imponiendo en la vida política española durante los últimos treinta años. La Constitución se define, ante todo, como un documento que expresa la voluntad normativa del Poder Constituyente, pero también es un sistema estructurado en torno a un principio, a un postulado referencial, que le confiere coherencia interna, esto es, que lo configura como un conjunto de elementos ordenados en red e interconectados de manera que unos y otros se influyen recíprocamente y carecen de sentido si prescinden de la idea que los informa y define como totalidad. No es posible considerar uno de esos elementos al margen de los otros y del conjunto del sistema en que se integra. Como tampoco cabe explicar la normatividad constitucional obviando la realidad sobre la que se proyecta y a la que está destinada a disciplinar. La Constitución como sistema normativo, para cumplir su misión imperativa precisa encontrarse inserta en otro sistema formado por la propia realidad política que pretende regular. Me parece que esa es la filosofía que desde su fundación inspira esta revista, y de ahí, a mi modesto entender, lo acertado del título que la preside: «teoría y realidad constitucional».

Si se admiten estas premisas, resulta obligado empezar recordando que el titulo X, dedicado a regular la reforma, se encuentra inserto y forma parte del proyecto colectivo de Constitución —algo que transciende bastante el texto de la misma— que se construyó en la transición, y tiene asignado un papel específico y cumple una misión perfectamente definida en ese proyecto que, además, está próximo a cumplir treinta y cinco años, lo que, en las categorías que manejaba Ortega, supone franquear sobradamente la frontera que 
separa dos generaciones. La generación que vive en la Constitución no es ya la que la redactó, y ese es un dato a tener muy en cuenta para juzgar las cosas con objetividad.

La Constitución de 1978, además del resultado de un proceso de transición democrática desde la dictadura nacida de la guerra civil — que no sería desatinado calificar como una evolución posibilista—, es también la hija legítima de una cierta lectura del pasado, de una valoración crítica de la historia que encierra un balance sobre nuestra acceso a la modernidad política a la cultura política moderna. Se corresponde con una determinada historiografía, o mejor dicho nace de ella... a modo de propósito de enmienda. Es decir, y en otras palabras, tanto la Constitución como su título X, se encuentran indisociablemente ligados a un juicio retrospectivo bastante negativo de cómo se había desenvuelto el discurrir histórico de la experiencia política y constitucional patrias que, a mediados de los sesenta y principios de los setenta, se fue forjando como mentalidad colectiva en la conciencia de la intelligentzia que aspiraba a convertir España en una democracia definitivamente consolidada. Esta lectura sostenía que el problema central de nuestra historia radicaba en la incapacidad crónica de las fuerzas políticas españolas para articular la vida colectiva en torno a una Constitución: las dos Españas. El fracaso constitucional del siglo XIX, la ley del péndulo del periodo isabelino que en el XX derivaría en contienda abierta, eran debidos — se pensaba en aquél momento- a la intransigencia de izquierda y derecha y a su debilidad para consensuar la política y organizar la convivencia cívica en torno a una idea de legalidad compartida, a unas instituciones y a unos símbolos comunes. En este sentido, la Constitución de 1978 se concibió, ante todo, como un colosal intento de superar esa enorme insuficiencia histórica; como la expresión tangible de la creencia en que los desequilibrios del pasado podían ser dejados atrás si todas las opciones políticas, partiendo de una Constitución material claramente asentada en la realidad, conseguían ponerse de acuerdo, o, por decirlo abiertamente, llegaban a pactar un texto constitucional normativo destinado a estabilizar la historia y a disciplinar férreamente la conducción de la política.

Se trataba de superar una historia de enfrentamientos fratricidas, gestando un gran consenso social y político que terminara fraguando en una Constitución acusadamente normativa. La legalidad constitucional y su fiel observancia eran la garantía suprema en la que se cifraba la gran esperanza de la democracia; la democracia por el derecho. En tanto que la democracia representativa se revelaba en 1978, en plena Guerra Fría, como la única alternativa viable en términos morales y éticos a la dictadura, incluso para aquellos que siguiendo las sugerencias de Elías Díaz, en su emblemático libro Estado de Derecho y sociedad democrática (1966), creían en la posibilidad de una evolución pacífica hacia otro tipo de democracia más avanzada. Y conviene insistir en que esa democracia representativa y de partidos era el reverso de la moneda del estricto respeto a una legalidad jerárquicamente articulada en la supremacía de la Constitución. La legalidad constitucional como forma de legitimidad, era el mensaje último que encerraba el trabajo de García de Enterría, La Constitución como norma jurídica, publicado por aquellos años y que resume perfectamente lo que se esperaba de la nueva Constitución. Pero además, el paradigma forjado en torno al binomio democracia de partidos — normatividad constitucional, no sólo se presentaba como la sola opción viable en el momento político español de fines de los setenta, sino que también resultaba ser algo que parecía coincidir plenamente con el modelo o arquetipo imperante en las naciones que pretendíamos emular y cuyo ordena- 
miento político nos habíamos propuesto como modelo a seguir, Alemania, Italia... y en menor medida de Francia y las monarquías nórdicas-. Posiblemente fue ese orden de consideraciones el que llevó en fechas tempranas a traducir al castellano el emblemático ensayo de Konrad Hesse, La fuerza normativa de la Constitución (1983). En aquel instante, la fe en el derecho, en la supremacía de una Constitución normativa que pudiera operar como referente central del sistema, como instrumento de estabilización de la democracia política, llegó a concitar el máximo grado de esperanza, desbordando cualquier precedente, incluida la segunda República, porque —e importa recordarlo - no era en la normatividad constitucional donde se cifraban los anhelos regeneracionistas de los autores de la Constitución de 1931. Pero la fe en el derecho se manifestaba en 1978 con una fuerza tal, que incluso los historiadores del derecho se ocuparon de rastrear los antecedentes de la normatividad en las primeras manifestaciones del constitucionalismo gaditano.

En ese contexto, el objetivo que latía en el proyecto de Constitución de 1978 era doble: centralizar la actividad del Estado y la sociedad entorno a la idea de Constitución e imponerla normativamente a la política. Había un anhelo compartido por todos: establecer las reglas del derecho y dirigir en clave imperativa la vida colectiva hacía una democracia pluralista organizada desde partidos sólidamente establecidos. El escrupuloso respeto al sendero constitucional-normativo y la implantación definitiva de la democracia vendrían a ser, por consiguiente, una misma cosa. La creencia era tan firme que incluso el nombre —y lo que es todavía más importante—, el contenido de la disciplina encargada de estudiar la materia en las facultades de Derecho españolas, cambiaron: el gaseoso Derecho Político fue sustituido por el innovador Derecho Constitucional. Se trata de un dato altamente revelador de la trascendencia que se quiso atribuir a la fuerza normativa de la Constitución. La voluntad de Constitución era normativa. El propósito de la Constitución se encaminaba a embridar la política a través del derecho, a sujetarla al dominio de lo normativo, a no dejar resquicio alguno ajeno a la juridicidad.

Si el marco ideológico del proyecto constitucional de 1978, situaba el objetivo de la Constitución en disciplinar normativamente la realidad política y social, el papel concreto que en ese paradigma correspondía a la reforma era el de encauzar procesalmente los cambios ordinarios. No era ese el cometido de los tratados internacionales, ni - por supuesto- del Tribunal Constitucional, aunque, bien es cierto, que la cuidadosa regulación de los primeros, y la introducción del segundo, respondían, poco más o menos, a la misma lógica del título X, garantizar la fuerza normativa de la Constitución; evitar que nada pudiera escapar al derecho. Y leyendo atentamente las dos importantes monografías que en los primeros años del régimen constitucional publicaron los profesores Pedro de Vega y Pérez Royo sobre la reforma constitucional, se consta que lo que primaba ante todo en aquél momento era la función de garantía, la necesidad de preservación de la fuerza jurídica de la Constitución. Aunque sus autores se preocupen de desmenuzar sus fundamentos políticos, por mucho que se esfuercen en desgranar la razón de fondo que justifica y explica la reforma, la función de la reforma en estos trabajos es siempre garantizar la supremacía normativa de la Constitución; la reforma es entendida como el procedimiento apropiado para mantener viva en el tiempo la capacidad de la Constitución para regular la política.

Pero con el paso de los años aquél proyecto de estabilizar la política a través de la fuerza normativa de la Constitución, parece haberse transmutado en la práctica en un re- 
chazo a todo cuanto pudiera implicar claudicación del derecho ante las exigencias de la realidad fáctica, a lo que pueda suponer apartarse del camino de la juridicidad más estricta. Parece coherente que cuando se deposita una confianza plena en la capacidad del derecho para regir la vida colectiva, se produzca simultáneamente un cierto reparo a la posibilidad de que la convivencia política pueda ser encauzada por factores ajenos a lo estrictamente normativo. $\mathrm{Y}$ en este punto hay que reconocer que resulta ciertamente difícil discernir hasta dónde llega la capacidad de la norma constitucional para encauzar jurídicamente la vida social, y dónde empieza el decalage entre norma y realidad, aquello que puede culminar en el constitucionalismo nominal y semántico que teorizara Loewenstein. Cuando la voluntad de constitución responde a un dato real y vivo, aunque sea en un programa de futuro o en un proyecto utópico que anima el quehacer de los hombres, y cuando se ha convertido en mera fancy ... en pura imaginación; dos extremos muy difíciles de separar en la era de lo virtual.

Es inevitable que un proyecto constitucional tan extremadamente juridicista como el que late tras la Constitución española de 1978, se resienta gravemente de la incapacidad del derecho de introducir el cambio en la continuidad normativa. Y también es comprensible que se hable de petrificación de la Constitución para referir el encastillamiento de los preceptos constitucionales sobre sí mismos renunciando a incorporar nuevas respuestas a realidades igualmente nuevas. Pero habría que preguntarse si el planteamiento del problema ha sido el correcto. ¿Nuestra fe en el derecho, en la legalidad, en la capacidad de la Constitución normativa para conducir la política es un desiderátum o el objetivo irrenunciable que hace posible la democracia?

Me inclino a pensar que nuestra lectura del pasado, la historiografía que construimos en la Transición, nos ha llevado a sobrevalorar la importancia y la capacidad de los factores normativos, o mejor dicho, de un determinado tipo de normatividad, la que se corresponde con el paradigma de derecho elaborado a finales de la Ilustración por Condorcet, Filangieri y Pagano y que tanto éxito tendrá en la posterior configuración del mito juridicista que hoy resulta fuertemente cuestionado en la cultura anglosajona por autores como Bailyn, Wood, Pocock o Richard Tuck. Es cierto que nuestra idea de derecho, estrechamente atada a la categoría de ley y de jerarquía normativa, no es la única posibilidad de entender el derecho, sino sólo una visión del mismo que ve en lo jurídico como diría Condorcet «una suerte de matemática social». Pero también es cierto que el propio concepto de lo normativo - y no sólo el paradigma de la juridicidad constitucional - se encuentra fuertemente cuestionado en el siglo XXI por su incapacidad de disciplinar la vida social. Decadencia del derecho o crisis de nuestras categorías jurídicas son cosas distintas, pero las dos coinciden en situarnos ante la dificultad de embridar una realidad social que parece escapar a cualquier pretensión de normatividad en las relaciones internacionales o de organizaciones que agrupan Estados como la Unión Europea, en la conducción de la fuerzas fácticas que mueven la política, en la sujeción de realidades virtuales como las finanzas, la información, los movimientos de los mercados... supuestos virtuales que inciden y condicionan las magnitudes reales, como la economía, la voluntad política de las sociedades o la capacidad productiva de un pueblo.

$\mathrm{Y}$ el fracaso es de tal magnitud que incluso significativamente se han invertido los términos. Se habla de «petrificación» de la Constitución, cuando a lo que posiblemente 
habría que referirse es a la superación, al desbordamiento de la Constitución normativa, de una Constitución conformada en el binomio legalidad-justicia constitucional que hace irrelevante que la reforma opere o no como garantía de cierre del sistema.

Conviene así mismo recordar también que la reforma como mecanismo de garantía de la juridicidad no está necesariamente presente en el momento constituyente americano dónde la Constitución era concebida más un mecanismo de garantía federal que otra cosa (y baste recordar el tenor literal del precepto que la regula para confirmarlo) y que tampoco aparezca en el primer constitucionalismo democrático europeo, en el que elabora Benjamín Constant, un autor que construye un modelo en abierta polémica con el paradigma juridicista americano. No es el caso de entrar ahora en detalles, pero no es casual que Constant objetara directamente a Filangeri sobre los límites y capacidades de lo normativo para regular la política, y negara radicalmente cualquier valor a las ideas de Constitución normativa y de reforma para imponer la supremacía de la política. La reciente publicación de sus obras olvidadas y de su crítica a Filangieri, ayuda mucho a entender lo que nos está pasando a los que hemos confiado en la fuerza normativa de la Constitución para atar al Ulises de Elster.

En definitiva, creo que asistimos a la consecuencia de una decisión que pudo tener sus razones para la anterior generación de constitucionalistas, pero que hoy muestra sus sombras. La Constitución entendida como mero y puro derecho, resulta incapaz de imponerse a la política y a la vida social. Máxime si se trata de una Constitución dotada de una fuerte carga dirigente, como la española de 1978. Y el giro experimentado en los últimos años por un autor como Gomes Canotilho que hizo de la normatividad constitucional ni más ni menos que el argumento central de su imponente tesis doctoral, es extraordinariamente elocuente en este sentido. Aunque para algunos pueda parecer una barbaridad, el Derecho Político está hoy en mejores condiciones de entender muchos de los problemas de nuestro momento actual, que el Derecho Constitucional entendido como pura y simple normatividad. Exigimos demasiado al derecho, y mucho más cuando lo limitamos a un paradigma tan reducionista como el que se corresponde con la idea de Constitución normativa que una parte significativa de nuestra doctrina ha venido utilizando en los últimos treinta y tres años.

Eso no ha sucedido en algunas de las naciones de nuestro entorno, dónde el derecho constitucional siempre fue un factor que debió compartir su función dirigente con factores políticos propios de una cultura moderna en el sentido que Michel Baker, Ozuf y Furet confieren al término, y las que la idea de República no fue reemplazada del todo por la noción de Constitución. Así sucede, sin ir más lejos, en los Estados Unidos, dónde, en lo que respecta a la cuestión que nos ocupa, las cosas han discurrido por un sendero muy diferente al nuestro. $Y$ es que contrariamente a lo que parecen señalar las apariencias, el estudio de la realidad política y constitucional norteamericana no se reduce sólo a las sentencias de la Corte Suprema.

Sin ir más lejos, y a título de ejemplo, de nada sirve la jurisprudencia de la Suprema Corte para entender el por qué de la última reforma constitucional norteamericana, ni tampoco de las razones que hasta la fecha han impedido que una cláusula similar a nuestro nuevo artículo 135 haya sido aprobada como enmienda a la Constitución Federal, justamente en el país en que Buchanan concibió el principio de equilibrio o autosustentabilidad presupuestario. 
En este sentido, conviene recordar que la XXVII enmienda que dispone que ninguna ley encaminada a modificar la retribución de los miembros del Congreso llegará a entrar en vigor en tanto no medie una renovación de la legislatura (1992), tiene una trayectoria altamente significativa. Su autor fue Madison, que la propuso hace más de dos siglos junto con las otras trece que componen la Declaración de Derechos. No habiendo sido ratificada por los dos tercios de estados que exige la Constitución, fue olvidada hasta que a finales de los setenta resultó redescubierta por un estudiante de derecho. El movimiento de replanteamiento de los valores democráticos que arranca en términos intelectuales del libro de Bailyn Los orígenes ideológicos de la revolución norteamericana (1967) consiguió su rápida ratificación en pocos años, mientras la ERA — la clausula que pretende garantizar en el plano federal la igualdad de sexos- o el precepto que exige el equilibrio presupuestario, hasta la fecha no han sido ratificadas y en consecuencia han decaído. Y no se trata de un hecho aislado, sino que se repite en problemas como la posibilidad de repetir mandatos (terms limits), o la financiación de las elecciones y que se inserta en la preocupación por regenerar la política por vías que no son solo el mero recurso al derecho.

Se nos puede objetar al respecto que se trata de otro contexto. Y es cierto, pero el ejemplo sirve para acreditar dos cosas. Qué no todo en el constitucionalismo norteamericano consiste en repetir sentencias, o aludir a razones estrictamente jurídicas. Y que en otras sociedades a las que pretendemos ver como modelo de vigencia del paradigma jurídico, los problemas políticos van más allá de los límites del derecho. Rawls no ha sido capaz de refundar el derecho como matemática social, o por lo menos no lo ha podido hacer de manera incontestable.

$\mathrm{Y}$ es que parece increíble que en la situación que nos encontramos, alguien pretenda resolver los enormes desafíos que están cuestionando todas las grandes verdades en que se asienta el mundo moderno, desde el derecho recogido en la Constitución. No es que nuestra Constitución se haya petrificado, es que desde hace muchos años, posiblemente desde el mismo momento en que redactábamos nuestra Constitución de 1978, empezaban apreciarse en el horizonte signos evidentes de que el derecho como creación moderna, era insuficiente para explicar y encauzar una libertad que no cabía encasillar tan sólo en el derecho al disfrute de bienes materiales, una exigencia de garantías que los tribunales de justicia resultaban incapaces de satisfacer suficientemente, una libertad política que no se conformaba con la representación y delegación del poder... Y cuando los problemas son otros, o sin serlo, tienen otra dimensión, las técnicas sociales - y no olvidemos que el derecho es una- precisan ser también otras.

En suma, no estamos ante la incapacidad de la Constitución española para disciplinar normativamente la vida política y social, sino en un momento de cuestionamiento del papel del derecho — o mejor del cuestionamiento de una determinada idea de derechocomo técnica de conformación social, que coincide justamente con el tiempo histórico en que nuestra conciencia jurídica parecía más convencida de la utilidad de la legalidad constitucional para conducir democráticamente la vida social. 


\section{JUAN CARLOS GAVARA DE CARA}

Las Constituciones tienen una necesidad de estabilidad y de seguridad jurídica, que necesariamente se conecta al poder de imponerse a la voluntad de los poderes constituidos. Esta capacidad generalmente se ha estructurado a través de las ideas de jerarquía o de supremacía, de las que se ha derivado en nuestro contexto la prohibición de infracción por parte de los legisladores estatal o autonómico y que se controla eventualmente por el Tribunal Constitucional o por el establecimiento de procedimientos de reforma rígidos. La introducción de nuevos preceptos o contenidos materiales en la Constitución deben responder a la idea de extender dichas cualidades conectadas a la supremacía de la Constitución a nuevas normas. Si no existe una voluntad de imponer dichos nuevos contenidos a los poderes constituidos carecería de sentido adoptar nuevas normas constitucionales, que en todo caso deberían responder a la corrección de los defectos de las actuales normas constitucionales o a la introducción de nuevas prescripciones para los poderes constituidos o el reconocimiento de nuevos derechos a los ciudadanos frente al poder público o el resto de la sociedad.

Evidentemente el mero contraste con otras Constituciones como la Ley Fundamental de Bonn (sesenta modificaciones desde 1949, aproximadamente una por año) nos demuestra que existen algunos factores externos a la propia lógica constitucional que han impedido una necesaria adecuación de la Constitución a su tiempo. Dichos factores pueden tener carácter jurídico o político o, lo que es más común en nuestro tiempo, ambos factores pueden estar entremezclados, de forma que oportunidad política y necesidad jurídica se identifican, evitando que de forma neutral se pueda valorar la adecuación de una reforma a una situación factual o material. La oportunidad política en nuestro contexto se suele medir en términos de legitimidad constitucional, es decir, se suele exigir una mayoría de continuidad, de forma que en términos semejantes a la mayoría que adoptó inicialmente la Constitución, se exige que se deba plantear la misma mayoría para su modificación. La necesidad jurídica se planteará cuando exista una voluntad de otorgar rango constitucional a la regulación de una materia o a la modificación de la norma constitucional ya existente. Evidentemente este doble factor se planteó en la reforma del art. 13.2 CE, pero en la actual del art. $135 \mathrm{CE}$ no ha sido así, ya que no se ha contado con la misma mayoría de apoyo político. En cualquier caso, esta oportunidad política debe ser medida y contrastada con otros factores de carácter más técnico, sobre todo cuando se trata de reformas parciales, ya que la introducción de nuevos preceptos se debe realizar de forma coherente con el resto de los preceptos y principios que permanecen inalterados al no ser reformados.

Este doble baremo basado en necesidad jurídica y oportunidad política ha ocasionado el fracaso de los anteproyectos o meras iniciativas de intentar reformar la Constitución, a pesar de que el sentido literal de los procedimientos de reforma hubiera permitido pensar que alcanzaba el cumplimiento de los requisitos planteados en un procedimiento de reforma que se ha considerado muy rígido. En nuestro caso, el peso de la oportunidad política ha sido amplio, ya que se pretende que la aceptación de la reforma alcance a casi todo el abanico parlamentario incluidos los partidos nacionalistas mayoritarios, pero algunas de las pretensiones de reforma planteadas por éstos serían incompatibles con los principios básicos en los que se asienta la Constitución. La petri- 
ficación de la Constitución se ha convertido en una especie de equilibrio de Nash, es decir, una ausencia de incentivos para cambiar la Constitución de una forma consensuada y que alcance la extensión de una mayoría política máxima. Las palabras mágicas consenso constitucional han sido fruto de un verdadero dilema del prisionero, ya que mediante el acuerdo todos los partidos políticos se incluyeron en su momento en la casilla del gana-gana, es decir, cedían en parte todos para obtener un beneficio común considerablemente más grande, existiendo, en consecuencia, incentivos para la cooperación y adquiriendo el texto constitucional una posición de centralidad desde el punto de vista de las aspiraciones de los partidos políticos. A este hecho contribuiría en dicho momento el carácter procedimental de numerosos preceptos constitucionales con un efecto de amplia desconstitucionalización del desarrollo material del texto constitucional.

Sin embargo, en el futuro cualquier modificación implicará que alguno de los sujetos pierda, ya que la modificación hará mover dicho punto de centralidad hacia una posición política diferente, más alejada de los respectivos planteamientos, lo que ocasiona que no se plantee la oportunidad política de su realización a través de mutuas acusaciones de pérdida de legitimidad política. De esta forma, mientras que la reforma no se sitúe en el punto de centralidad entre los diferentes ejes de reivindicación constitucional, es decir, al punto de encuentro en política constitucional de los partidos políticos, no será posible eliminar la petrificación constitucional. La Constitución no es tratada como el texto normativo de la normalidad, sino como un mito de un consenso creado en base a la excepcionalidad o a la existencia de incentivos que favorecían la adopción de decisiones para no encontrarse en una situación peor y la transacción en base a la obtención final decisiones verdaderamente mayoritarias.

En mi opinión dichos incentivos en la actualidad fundamentalmente serán de carácter externo fruto del cumplimiento de las obligaciones europeas, punto común de encuentro de las fuerzas políticas y en el que se tiende a converger y seguir sus directrices, incluso de contenido constitucional, ya que la adopción de decisiones racionales, de profundización interna en los principios estructurales tan solo han permitido generar la adopción de decisiones infraconstitucionales, es decir, reglas no incluidas en la Constitución a pesar de que materialmente responden a su misma filosofía. En ocasiones dicha vía se convierte en un claro intento de superar los márgenes de la Constitución, ocasionando mutaciones o modificaciones encubiertas, que eventualmente se pueden encontrar con el control del Tribunal Constitucional dado nuestro sistema de control abstracto y concentrado.

No obstante, creo que en esta materia se debe diferenciar con nitidez entre los principios estructurales, es decir, las ideas o decisiones básicas adoptadas mediante la Constitución y las normas sobre su concreción de carácter sustancial o material y procedimental. En definitiva, las Constituciones contienen reglas y principios, y generalmente estos últimos se ven afectados en menor medida por las posibilidades de una modificación, ya que sobre dichos principios recaen los acuerdos básicos para conseguir un consenso y una aceptación generalizada en nuestra sociedad. En nuestro caso el peor factor resulta de la identificación, al menos desde una perspectiva política, de las reglas con los principios, al intentar extender sus peculiares características y contenidos al conjunto de las normas constitucionales. Las reformas parciales se dirigen e inciden sobre reglas 
concretas constitucionales, en ocasiones para profundizar los principios establecidos en el texto constitucional, pero no dejan de ser eso, modificaciones parciales que no inciden en los principios estructurales, en los que debe recaer fundamentalmente el acuerdo consensual de las fuerzas políticas. El consenso no se puede perpetuar, ni alcanzar a todos y cada uno de los preceptos constitucionales, ni se puede argumentar que se ha producido una ruptura por la modificación de un precepto concreto, ya que el consenso no es en si mismo un bien o un valor mítico con naturaleza y desarrollo propio, de forma que las reformas parciales deben producirse respetando las reglas del procedimiento de reforma y no obligando a cumplir un criterio de oportunidad política no existente, sobre todo cuando no afecta a los principios estructurales.

\section{ALBERTO LÓPEZ BASAGUREN}

Tengo una opinión negativa.

No creo, como principio, que sea necesario estar realizando ajustes continuos al texto constitucional; o que cada generación deba hacer su propia Constitución, siguiendo la idea de Thomas Jefferson. Me parece más sensata y eficaz políticamente la prudencia de James Madison sobre la proliferación de «Convenciones constituyentes». Pero no hay que confundir las pretensiones de dar nacimiento a un «nuevo» régimen constitucional con las necesidades de «adaptación» de la Constitución, manteniendo — reforzando— sus elementos fundacionales.

Uno de nuestros problemas específicos es que en España se identifica en exceso reforma de la Constitución con cambio de los fundamentos del sistema vigente. Lo hacen algunos defensores de la necesidad de reformar la Constitución y, también, algunos de los que se oponen a reformarla.

El carácter más o menos necesario de las reformas constitucionales depende de las circunstancias políticas de cada país, de cada época, del acierto o desacierto en las regulaciones constitucionales, de los cambios en la sociedad de una época determinada y de la forma en que afecten al eficaz funcionamiento del sistema político, de las necesidades y de los sentimientos de los ciudadanos de ese tiempo y ese lugar. En unas condiciones determinadas, en un país y época determinados, una Constitución puede mantenerse sin ninguna reforma sin que ello afecte ni al funcionamiento del sistema político ni a la adhesión de los ciudadanos al sistema constitucional. O pueden ser plenamente idóneas - y suficientes - las adaptaciones que se vayan haciendo por la vía de la interpretación de la Constitución, siempre que sean así aceptadas y sentidas por los ciudadanos y las fuerzas políticas.

En mi opinión, la Constitución de 1978 acertó en sus opciones fundamentales; por ello, mi defensa de la necesidad de reformar la Constitución se sitúa en el ámbito de las «adaptaciones» - lo que no impide que puedan ser profundamente significativas-. Su objetivo debe ser lograr un funcionamiento más eficaz y adecuado del sistema político y reforzar la vinculación de los ciudadanos con el sistema constitucional.

Creo que durante los casi treinta y cinco años de vigencia de nuestra Constitución se ha puesto de manifiesto la necesidad de realizar adaptaciones de la Constitución, mediante su reforma, con la pretensión de lograr aquellos dos objetivos. Creo que durante 
este periodo era necesario haber introducido cambios en algunas disposiciones constitucionales que mejorasen el funcionamiento del sistema político, que se adecuasen mejor a la realidad, a las necesidades de la sociedad, y que, al mismo tiempo, fuesen un cauce para renovar el consenso entre las fuerzas políticas sobre la Constitución y para reforzar el sentimiento de vinculación de los ciudadanos al sistema político; tanto de los pertenecientes a las generaciones que llegaron a la madurez después del periodo constituyente, como de los que vivimos el nacimiento de la Constitución.

Vivimos en un entorno político, el de la Europa occidental continental, a cuya tradición constitucional estamos vinculados. En este entorno se han producido transformaciones de importancia durante el periodo de vigencia de nuestra Constitución. Y los países de tradición constitucional más solvente han afrontado durante este tiempo distintas reformas constitucionales. Alemania, Suiza, Francia, los Países Bajos, Suecia... han realizado profundas y, en muchos casos, reiteradas reformas constitucionales en los últimos decenios. Y, fuera de la tradición continental, en un sistema constitucional tan singular, a estos efectos, como el del Reino Unido, se está debatiendo sobre la reforma constitucional desde hace varios decenios, con un gran trabajo parlamentario en ese sentido. Se trata de sistemas que afrontan las reformas constitucionales como una vía de revitalizar los principios básicos del sistema, frente a ejemplos, como Bélgica, en el que las sucesivas reformas constitucionales parecen ir jalonando un proceso de derribo. Aquellos son los ejemplos que debemos seguir.

En el caso de España, además, en 1978 se dejaron abiertas algunas cuestiones, dado que no estaban claros los caminos por los que se adentraría nuestro sistema político, lo que ha cambiado profundamente tras casi treinta y cinco años de desarrollo.

En España, frente a lo que viene ocurriendo en nuestro entorno y a pesar de nuestros específicos motivos, la idea misma de reforma de la Constitución se ha convertido para muchos en un tabú. La reforma constitucional no se puede trivializar; sobre todo, las reformas constitucionales que algunos pretenden; pero tampoco se puede demonizar, convirtiendo la Constitución en un texto prácticamente intocable. Hemos llegado, así, a una situación de bloqueo que, en mi opinión, las dos reformas constitucionales que han tenido lugar (en 1992 y en 2011), lejos de superar, han reforzado, por la forma en que se han realizado. Y esto es profundamente negativo para el futuro de nuestro sistema político, porque limita la capacidad de adaptación de la Constitución a las circunstancias cambiantes.

En contra de lo que algunos parecen pensar, la capacidad de las fuerzas políticas de afrontar reformas de la Constitución de forma consensuada no debilitan, sino que refuerzan la Constitución. Y, si se gestionan adecuadamente, suponen una pedagogía democrática de gran trascendencia para reforzar el sentimiento ciudadano de adhesión a la Constitución como un instrumento vivo.

La valoración negativa sobre la petrificación de la Constitución durante estos casi treinta y cinco años se basa, por tanto, en la incapacidad que han demostrado los partidos políticos para renovar un consenso constitucional que permitiese adecuar la Constitución a los cambios que se han producido en Europa y en España, mejorando el funcionamiento del sistema político y reforzando la adhesión ciudadana al sistema constitucional. 


\section{ANTONIO LÓPEZ PINA}

Al fin de una mejor comunicación, el respeto que debo a los lectores y la gratitud que por invitarme merece el Sr. Alzaga, editor de la Revista, unas observaciones sobre la dogmática de la reforma constitucional, a modo de punto de partida. Las mismas deben sentar los presupuestos de teoría constitucional de mi respuesta: a) Poder constituyente y fuerza normativa de la Constitución; b) la defensa de la Constitución, por vía de excluir la modificación y de limitar las reformas constitucionales; c) la reforma constitucional:

1. Dogmática de la reforma constitucional, a título de consideraciones previas

a) Poder constituyente y fuerza normativa de la Constitución. La Constitución nace siempre con la ambición, de configurar y vincular normativamente Estado, sociedad, y las relaciones internacionales, precisamente concertadas entre Estados constitucionales, que por su entrada en vigor se convierte en mandato de obligado cumplimiento para los poderes públicos y los ciudadanos. Ese es el punto de partida.

A falta de mejor recurso, invito al lector a seguir, de mi pluma, el pensamiento sobre tal tema de Konrad Hesse' ${ }^{1}$ :

«El Derecho constitucional debe contener en sí mismo no solamente la garantía de su eficacia, sino asimismo el aseguramiento de la preservación de su contenido. Ello comprende la tarea de reforzar en lo posible la Constitución, bien, frente a amenazas, bien, contra su supresión; la protección de la Carta Magna vale asimismo para la existencia del Estado, que como Estado constitucional solamente, en el proceso político constitucionalmente ordenado, existe y puede ser preservado».

b) La defensa de la Constitución. «A tal protección sirven los institutos que deben garantizar la Constitución contra ataques desde el exterior y desde ella misma, contra asaltos de los enemigos, en fin, contra la operatividad desde «arriba» o desde «abajo».

Ciertamente, tales institutos no comportan una protección absoluta del texto constitucional:» La existencia y preservación de la Constitución es, sobre todo, una cuestión de su fuerza normativa. Cuanto más corresponda el orden constitucional a las circuns-

1 HESSE, K., Grundzüge des Verfassungsrechts der Bunderepublik Deutschland, 20., neubearbeitete Auflage, Heidelberg: C. F. Müller Verlag, 1995; id., Ausgewählte Schriften, HÄBERLE, P., HOLLERBACH, A., Hrsg., Heidelberg: C. F. Müller Verlag,,1984. Para una ilustradora interpretación actual del pensamiento de Hesse, vid. AZPITARTE, M., Konrad Hesse en el siglo XXI, Escritos de Derecho constitucional, $2^{\text {a }}$ edición, edición de CRUZ VILLALÓN, P., y AZPITARTE SÁNCHEZ, M., CEPC, Madrid, 2011. Cfr. Asimismo, WAHL, R., Verfassungsänderung, Verfassungswandel und Verfassungsinterpretation, Berlin: Duncker \& Humblot, 2008; HOFMANN, H., Änderungen des Grundgesetzes. Erfahrungen eines halben Jahrhunderts, in: Festschrift für Thomas Raiser zum 70. Geburtstag am 20. Februar 2005 R. DAMM; P. W. HEERMANN; R. VEIL Hrsg. Berlin: Walter de Gruyter Recht, 2005; SCHMITT, C, Verfassungslehre, Berlin: Duncker \& Humblot, 1928; MURSWIEK, D, Die Verfasungsgebende Gewalt nach dem Grundgesetz für die Bundesrepublik Deutschland, 1978; E. -W. Böckenförde, Die verfassungsgebende Gewalt des Volkes-Ein Grenzbegriff des Verfassungsrechts, 1986; HÄBERLE, P, Die verfassungsgebende Gewalt des Volkes im Verfassungsstaat, Archiv des öfentlichen Rechts 112 (1987); KIRCHHOF, P, Die Identität der Verfassung in ibren unabänderlichen Inbalten, Handbuch des Staatsrechts I \& 19; SCHNEIDER, H-P, Die verfassungsgebende Gewalt, Handbuch des Staatsrechts VII \& 158; EHMKE, H, Verfassungsänderung und Verfassungsdurcbbrechung, Archiv des öffentlichen Rechts 79 (1953 1 54); GRIMM, D, Verfassungsfunktion und Grundgesetzreform Archiv des öffentlichen Rechts 97 (1972). De la bibliografía española, cfr. Pedro de Vega, La reforma constitucional y la problemática del Poder constituyente, Madrid: Tecnos, 1985 ; PÉREZ ROYO, J., La reforma de la Constitución, Madrid: Congreso de los Diputados, 1987. 
tancias de la situación histórica, cuanto mayor sea la disposición de la sociedad y de los gobernantes a considerar vinculante la Constitución y cuanto más decidida sea la resolución a poner al día contra toda suerte de resistencias los contenidos constitucionales, con tanta mayor seguridad se evitarán o podrán ser contenidas tales amenazas. Cuando y dondequiera falte o desaparezca el consenso fundamental en el que se basa la fuerza normativa de la Constitución, ésta pierde los fundamentos de su fuerza existencial y todos los institutos de garantía se evidenciarán impotentes».

No debe interpretarse tal tesis en el sentido, de que sean superfluas las garantías institucionales de existencia de la Constitución. Sí, en cambio, que «la tarea de defensa de la Constitución debe residir en el robustecimiento de la fuerza normativa de la Constitución y que nunca sobreestimaremos la importancia de tales garantías».

Ello vale, sobre todo, para lo que Scheuner denomina garantías constructivas, "contenidas en las reglas organizativas y de procedimiento constitucionales, que deben impedir, que la apertura material genuina de las normas constitucionales pueda ser reemplazada por fines que se excluyan recíprocamente y por una petrificación inaccesible para fuerzas plurales: o lo que es lo mismo, la ordenación y el equilibrio de los poderes». La vitalidad de la Constitución «sólo puede traer causa del acatamiento y del libre y continuo aggiornamento; nunca, de prohibiciones y medidas de fuerza».

c) La reforma constitucional. Exclusión de modificaciones de la Constitución y limitación de la reforma constitucional

La realidad histórica puede poner en dificultades a la Constitución, tal como reza su texto literal. En tal circunstancia, el texto constitucional puede ser adaptado a una nueva realidad, por vía de reforma (Verfassungsänderung). Por reforma constitucional ${ }^{2}$ se entiende la enmienda del texto constitucional. Hay que distinguir la reforma de la transgresión, el quebrantamiento o la ruptura constitucional (Verfassungsdurchbrechung)3); es decir, la desviación de la literalidad del texto en casos concretos (sin enmienda del texto). Esta desviación o transgresión se diferencia asimismo de la mutación constitucional (Verfassungswandlung) ${ }^{4}$, que no afecta a la literalidad del texto mismo — que no es alterada-, únicamente concreta el contenido de las normas constitucionales; habida cuenta de la amplitud y apertura de numerosas normas constitucionales, bajo diferentes supuestos, pueden dar lugar a diferentes resultados y a un «cambio», en términos de «mutación». Según Hesse, «la problemática de la reforma constitucional comienza justo allí donde finalizan los márgenes de mutación constitucional».

Cuando, en una Constitución, que deja pocas posibilidades al cambio, se dificultan las reformas, hablamos de una Constitución rígida ${ }^{5}$. En tales casos, es inequívoco el contenido de la norma constitucional, y la Constitución encuentra dificultades para cumplir

2 EHMKE, H, Grenzen der Verfassungsänderung, 1953.

3 LEIBHOLZ, Die Verfassungsdurchbrechung, Archiv des öffentlichen Rechts, 1932; EHMKE, H, Verfassungsänderung und Verfassungsdurchbrechung, Archiv des öffentlichen Rechts, 1953.

4 JELLINEK, G, Verfassungsänderung und Verfassungswandlung, Berlin, 1906; Hsü Dau-Lin, Die Verfassungswandlung, 1932.

5 BRYCE, Flexible and Rigid Constitions, en Studies in History and Jurisprudence, Oxford University Press, 1901. version en castellano, Constituciones flexibles y Constituciones rígidas, Madrid: Instituto de Estudios Políticos, 1963. 
su función en la realidad histórica de un Estado. «Tampoco es mejor el caso de una Constitución que deja poco margen para la mutación, la cual puede ser cambiada a discreción, mediante reformas constitucionales factibles en cualquier momento y sin particular dificultad. Ciertamente, en el supuesto de Constituciones rígidas, tal fórmula hace posible una rápida adaptación; lo que sucede es que en tales casos, tampoco cumple la Constitución su tarea para Estado y sociedad, como orden jurídico fundamental del Estado, al malbaratarse una parte esencial de su potencia estabilizadora. Por el contrario, se corresponde al sentido y la tarea de la Constitución, cuando en su texto se deja margen para cambios constitucionales, sin perjuicio de los límites existentes a la reforma; una tal fórmula permite cierta elasticidad y da lugar a la relativa estabilidad, tan importante para la función objetiva de la Constitución».

En el caso de la Constitución Española, de 1978, nació con voluntad de configurar y vincular normativamente a Estado y sociedad (art. 9.1 EC). Desde sus orígenes, nuestra Carta Magna ha estado sometida a significativas mutaciones constitucionales por vía de interpretación, y a transgresiones, en la peor tradición celtibérica contemporánea, por nuestros mandatarios institucionales, por la Oposición, al margen del color político, o por el sector privado de la economía: sin distinción, ya sean mandatarios nacionales o regionales; desde el Consejo General del Poder judicial al Tribunal Supremo; desde algunos Magistrados del Tribunal Constitucional a significativos actores de la sociedad civil ${ }^{6}$.

La dramática historia contemporánea de España, y su correlato de vulneración sistemática de los derechos fundamentales, explican el acuerdo, en las Cortes Constituyentes, sobre los derechos y libertades y, su reforzada garantía (art. 53 EC), o bien, mediante barreras a la reforma constitucional (art. 168 EC). Entretanto, han corrido ríos de tinta sobre la asociación del consenso constituyente al silencio o a la memoria histórica ${ }^{7}$. Que hasta el incidente constitucional, concertado a tres bandas entre el Presidente del Gobierno, el Canciller Sra. Merkel y el líder de la Oposición mayoritaria, del pasado mes de septiembre de 2011, sólo haya tenido lugar una reforma del art. $13 \mathrm{CE}^{8}$, se explica, accidentalmente, por supuesto, por el alto umbral exigido en los arts. 167 y $168 \mathrm{CE}$ para la reforma. La causa más directa empero ha residido no en la defensa por quién sea de los intereses generales ${ }^{9}$ sino en los filisteos intereses partidarios y los consiguientes antagonismos siempre prestos a sacrificar no importa qué bien jurídico.

En concreto: mi valoración del largo período de paz jurídica, desde diciembre de 1978 es por demás positiva, en la medida en que la fuerza normativa de la Constitución ha mantenido la garantía de los derechos fundamentales y, por ende, de la igual libertad

6 LÓPEZ PINA, A, Los intereses generales, mandato constitucional, Anales, Madrid: Real Academia de Jurisprudencia y Legislación, 2007; id. La Constitución territorial de España. El Orden jurídico como garantía de la igual libertad, Madrid: Marcial Pons, 2006; id. Constitucionalismo y «religión civil», en VV AA División de Poderes e Interpretación. Hacia una Teoría de la Praxis constitucional, edición y prólogo de A. López Pina, Madrid: Ed. Tecnos, 1987.

7 LAVILLA, L Política de la Memoria, Madrid: Real Academia de Ciencias Morales y Políticas, 2008. LÓPEZ PINA, A, La Interpretación y el Procesamiento de la Historia en España, Madrid: sistema, nº 214, enero 2010. ALZAGA, O, Del consenso constituyente al Conflicto permanente, Madrid: Editorial Trotta, 2011.

8 En agosto de 1992 para introducir, en el art. 13, el derecho de sufragio pasivo de los extranjeros en las elecciones municipales.

9 LÓPEZ PINA, A, Los intereses generales, mandato constitucional, op. cit. n pd p 6. 
de todos bajo el Derecho, y permitido tanto una política exterior de España conforme al mandato constitucional —excepción hecha de la participación en la guerra de Irak-, como la incorporación a la Unión Europea.

Tal juicio no empece, a mi conciencia, de la necesidad de algunas reformas constitucionales, que más abajo relaciono.

2. ¿Querría adelantarnos su opinión sobre el Título X que rige «la reforma constitucional»? Es decir, ¿Sería favorable a abordar la reforma de algún punto de nuestro sistema de reforma de la Constitución? Y, más en concreto, ¿Piensa que la no actualización de la CE se debe a la dificultad de alcanzar acuerdos magnos entre los partidos políticos españoles o a otras causas?, ¿Qué opinión le merece el proceso dotado de especial rigidez recogido en el art. 168? Y ¿Cree Vd. bien definidos en el mismo artículo los ámbitos de la Constitución sujetos a esta vía agravada o, por el contrario, incluiría alguno más, o exceptuaría preceptos constitucionales actualmente sólo modificables por esta vía dificultativa de su reforma?

\section{ELOY GARCÍA}

Mi respuesta a esta pregunta es consecuencia de lo dicho anteriormente. En la Transición española no operó un Poder Constituyente claro en el sentido tradicional del término. El cambio se produjo utilizando la legalidad para saltar de una legitimidad carismática o quizás de un régimen de fuerza atemperado o dulcificado por los años, a un sistema de legitimidad democrático representativa. Y para hacerlo hubo que prescindir de la teoría del Poder Constituyente.

Nuestro modelo constitucional, a diferencia del de nuestros vecinos portugueses, nació de la voluntad de una sociedad que no quería revoluciones, que deseaba conservar la continuidad de la Constitución material heredada del franquismo e insertarlo en una lógica democrática. La Transición española es ante todo antirevolucionaria, nace del deseo de los españoles de evitar a toda costa la destrucción del modelo social surgido del franquismo; intentar acabar en 1975 con la sociedad creada por Franco equivalía a una auténtica revolución, es decir hubiera supuesto la destrucción de todo un orden social que iba a defenderse violentamente. Pero esto no sucedió y esa es precisamente la nota distintiva de nuestro proceso no constituyente.

El Poder Constituyente no es otra cosa que la pars construens de la Revolución. Las revoluciones destruyen, rompen con el pasado, introducen una nueva legitimidad que sólo se justifica en sí misma, sobre sus propios valores, o para decirlo en términos actuales, es autopoiética. Y el Poder constituyente cumple la función de introducir el aspecto constructivo allí dónde la Revolución ha generado el vacío; allí donde la Revolución ha operado como poder o pars destruens. Pero eso sólo sucede en la teoría clásica. En los Estados Unidos con la revolución que proclamando la Independencia hizo surgir una realidad nueva que por no reconocerse en el pasado necesitaba ser creada o fundada desde sus cimientos. En la Alemania de Weimar, en la que el Poder Constituyente — como explica Walter Jellinek - es hijo de la revolución. En varios de los países europeos occidentales después de 1945. En Portugal, con la Revolución de los capitanes de abril. Sin embargo no ocurre allí dónde no se ha producido una Revolución. Dónde no media la Revolución, 
no hay pars destruens y en consecuencia el Poder Constituyente no puede operar como pars construens, como poder que construye desde el estado de la sociedad natural del que hablaban los clásicos.

La transición española en este sentido, es determinante. En España no hay función destruens seguida de acción costruens, lo único que se hace es proceder a redefinir la política. La Constitución y las cámaras que la redactan estaban preocupadas por dos cosas, por garantizar la continuidad sustancial de la Constitución material que venía del franquismo, y en eso el papel de la Corona resulta determinante, y por introducir las instituciones propias del Gobierno participativo y hacerlas compatibles con las exigencias de la idea democrática representativa, derechos fundamentales y pluralismo de partidos. Y lo logra de una forma admirable, tan admirable que será la primera de una serie de Constituciones que vendrá después; la primera de las Constituciones posmodernas, en tanto que la portuguesa será la última de las revolucionarias; el último episodio de los modernos.

Pero todo tiene su reverso. El precio a pagar es, además de otras cosas, un indiferentismo ideológico que como señalara con agudeza en su día Javier Jiménez Campos, informa nuestro texto constitucional. Una Constitución indiferente en términos ideológicos, pero que al mismo tiempo es el resultado de un difícil proceso de consensos - al que Óscar Alzaga ha dedicado un reciente y logrado trabajo- se traduce necesariamente en un título $\mathrm{X}$ en el que conviven la renuncia a la intangibilidad constitucional con un procedimiento de reforma que parece ideado para evitar que se puedan efectuar reformas, salvo cuando se cuente con un altísimo acuerdo. Y en ese sentido permítaseme señalar el singular papel que juega el pueblo en la reforma, que mientras en los restantes mecanismos constitucionales se encuentra constreñido siempre a expresar su voluntad mediante representantes, o todo lo más a hacerlo de forma no vinculante y a petición expresa de los otros órganos constitucionales (referéndum del artículo 92), en este caso lo hace obligatoriamente en el supuesto de reforma agravada y con cierta facilidad cuando media reforma sencilla. Semejante recurso sólo se explica como un intento de disuadir de proceder a cualquier reforma que no esté ampliamente consensuada al menos por un $90 \%$ de las cámaras, lo que en términos de representación política supone todavía la exigencia de un mayor respaldo.

Posiblemente el titulo X sea en este contexto la parte o norma más inmodificable de nuestra Constitución. El título de la reforma está pensado para reducir al máximo las posibilidades de cambio desde la propia Constitución y ello se debe a una decisión consciente, motivada tanto por la dificultad de construir los puntos de acuerdo — especialmente en cuestiones de naturaleza territorial - como por la peculiar voluntad de Constitución que inspiraba nuestra Carta Magna: el deseo de imponer el derecho y la forma constitucional a una política que en el pasado se había escapado de la horma jurídica. Proceder a reformar el mecanismo de reforma por la vía directa de sustituir o alterar esté o aquél precepto, equivaldría poco más o menos que a cambiar la propia esencia de la Constitución que no es otra que la de extender el consenso. Aquí reside el corazón de nuestra Constitución. Y por eso cualquier reforma directa de la reforma, atacaría de lleno el núcleo de la Constitución. Quedan eso si las vías laterales. La interpretación, especialmente la que efectúan el Tribunal Constitucional y los demás operadores jurídicos, empezando por el Parlamento que aunque opere a titulo de actualización subordinada a la supremacía de la norma, en realidad va siempre más allá, y la vía de los tratados in- 
ternacionales que guste o no, suponen una puerta abierta a la desconstitucionalización de la Constitución, similar a la que en otro tiempo fueron las delegaciones legislativas en relación con la potestad legislativa del Parlamento.

Pero lo que hace años pudo significar la violación de un dogma, la irreformabilidad de hecho de una Constitución que amenaza con desconocer las nuevas exigencias que constantemente está generando una política en la que muy pronto se manifiesta el hecho nuevo, hoy tiene menos importancia, es menos dramática, por que se diga lo que se diga, en realidad la Constitución no es ya la fuente que condensa toda la vida política y social, sino un elemento más de un sistema que se configura como una network, como una red de trabajo enormemente compleja dónde lo normativo vale en la medida en que actúa con modestia y sobre todo se adecua perfectamente a la realidad concreta que tiene delante. Es decir el constitucionalismo actual debe aceptar la renuncia a los grandes enunciados y hacer de sus principios supuestos tan realistas y tan apegados a los hechos que su fijeza sólo se mantenga en tanto no se introduzca un hecho nuevo. En resumen: recuperar la vieja noción de principio que exhibiera Constant en su famosa polémica con Kant, «un principio es el resultado general de un cierto número de hechos particulares. Todas las veces que el conjunto de esos hechos sufre algún cambio, el principio se modifica y esa modificación deviene a su vez principio». Ello nos depararía además otra utilidad, atajar el mayor problema de la postmodernidad, a saber: la dilución de los postulados en hechos singulares, de lo general en lo particular, con la consecuente imposibilidad de acudir a las categorías generales que es dónde únicamente tienen sentido las ideas constitucionales.

En dos palabras, proceder a modificar el titulo $\mathrm{X}$ de la CE, puede significar muy bien, abrir el camino para introducir una colección de reformas que generen enormes esperanzas, y que posiblemente despierten una gran polémica, pero que terminen degenerando en una Constitución paralela como la que en su último trabajo señalaba el profesor Giorgio Lombardi se habían finalmente impuesto en Italia tras la no superada crisis de los noventa. Una Constitución como la nuestra, sin grandes definiciones de fondo, pero con una mecánica constitucional e institucional muy medida y procelosa, puede tener el riesgo de degenerar cuando las reformas parciales llegan a romper un sistema y una lógica que a pesar de ser únicamente formal, mantiene perfectamente toda su coherencia interna. Ignorar ese extremo implica generar graves problemas en el ámbito territorial y también en los mecanismos de articulación de la representación política, y pudiera llevar a una desarticulación del sistema. Modificar el titulo X sería dejarlo expedito para albergar reformas destinadas a calmar la opinión, no a crear un orden; a destruir lo existente, no a remplazarlo por un instituto o proceder a lo que se considera mejor.

\section{JUAN CARLOS GAVARA DE CARA}

En mi opinión, salvo algunos desajustes procedimentales, no creo que tenga mayor problemática la introducción de procedimientos rígidos o muy rígidos de reforma constitucional. En todo caso, en último extremo se pueden aprobar reformas concurriendo la voluntad de los dos principales partidos del arco parlamentario, que frecuentemente llegan a acuerdos en numerosos puntos de la vida jurídica, política, social o económica. La dificultad de emprender la reforma ha respondido a algunas de las cuestiones que se plan- 
teaban en el punto anterior a la hora de mantener el consenso original, intentar incorporar al mismo a los partidos nacionalistas mayoritarios que tienen distintos incentivos e intereses y en valorar su correcta proyección en el futuro. En cualquier caso, no creo que la regulación del Título de la reforma de la Constitución haya sido la causa de sus problemas de petrificación.

Ahora bien, el título de la reforma constitucional precisa una serie de puntualizaciones o aclaraciones:

a) En contra de lo que puede pensarse el procedimiento agravado no es una ampliación de requisitos del procedimiento simple. Se trata de dos procedimientos distintos, que no se pueden unir. No obstante, la división de materias a efectos de usar un procedimiento u otro no es simplemente numérica, ya que existen normas cuya modificación o derogación, a pesar de que parece que deberían realizarse por el procedimiento simple, entraña una modificación de preceptos que deben seguir el procedimiento agravado. Por ejemplo, la modificación del art. $14 \mathrm{CE}$ (art. $167 \mathrm{CE}$ ) implicaría la reforma del art. $1 \mathrm{CE}$ (art. $168 \mathrm{CE}$ ), la modificación del art. 66 CE implicaría la modificación del art. $1 \mathrm{CE}$, la modificación del art. 106.2 CE implicaría la reforma del art. 9.3 CE, etc. En este sentido, debería ser más preciso en su formulación, ya que la modificación o introducción de nuevos preceptos en el título preliminar o en sus proyecciones en el resto de la Constitución tiene implicaciones, que no siempre se encuentran bien resueltas. Desde otra perspectiva, la inclusión de todos los preceptos del Título II entre los sometidos al procedimiento del art. $168 \mathrm{CE}$ es innecesaria, ya que su finalidad originaria se alcanzaría limitando el mismo efecto a algunos artículos como los art. 56 y 57 y a algunas concordancias, sin hacerlo extensivo a todo el Título.

b) Aunque el art. $168 \mathrm{CE}$ no lo menciona específicamente, la modificación de los art. 167 y 168 solo es posible por el procedimiento agravado. De otro modo, el art. 168 CE carecería de efectividad, ya que en un proyecto de reforma ordinaria se podría insertar un artículo que modificase o derogase el art. 168 CE. Se trata de una laguna técnica, que se puede resolver por vía interpretativa, aplicándose una técnica similar a la del fraude a la ley o fraude, en este caso, a la Constitución, pero que para dotar de seguridad jurídica al propio texto constitucional debe ser mencionada de forma expresa.

c) El producto de la reforma constitucional no es una ley constitucional (como en Italia), sino idéntica a la Constitución. La Constitución no es formalmente una Ley, sino un acto normativo de distinto nombre y condición (tal como se publicó en el BOE), su reforma no se hace mediante leyes, sino mediante nuevos textos constitucionales. La reforma, desde un punto de vista material, no es una ley de reforma, sino Constitución. Ahora bien, la regularidad del procedimiento de reforma ha de estar garantizada, ya que el Título X CE, como las demás partes de la Constitución, ha de estar protegido frente a su vulneración, de ahí que la reforma debería ser susceptible de control por el Tribunal Constitucional para que, en el supuesto de que tal reforma fuese impugnada, se pudiera comprobar su validez, es decir, se debería comprobar si se han respetado las reglas de procedimiento y las materias excluidas. No obstante, ni la Constitución ni la LOTC han previsto expresamente esta competencia (una y otra sólo se refieren al control de constitucionalidad de las «leyes»), aunque se podría sostener que el término «leyes» engloba al de «Constitución», estimándose que las reformas constitucionales se realizan mediante «leyes de reforma constitucional» y de esa manera resolverse el problema de la compe- 
tencia del Tribunal. La competencia del Tribunal Constitucional no se apoyaría, pues, en una atribución explícita, sino implícita, derivada del carácter mismo de la Constitución y de la posición y naturaleza del propio Tribunal Constitucional. En cuanto a la vía para controlar la constitucionalidad de la reforma, parece que sería la del recurso de inconstitucionalidad. Este es un punto que debe corregirse, ya que la visión procedimental de nuestra Constitución exigiría por lo menos eso, un reconocimiento del control procedimental en la utilización de los procedimientos de reforma constitucional.

d) Un problema a considerar es el de las llamadas reformas constitucionales no expresas o mutaciones constitucionales. A estos efectos deben distinguirse dos supuestos: el de las adaptaciones interpretativas de la Constitución y el de las mutaciones propiamente dichas. A través de la actividad interpretativa que experimentan las normas constitucionales, con la mayor o menor autoridad que ejerza el Tribunal Constitucional, éstas pueden cambiar de sentido, adaptándose a nuevas realidades. Esa adaptación del texto mediante la interpretación no es exactamente una mutación constitucional, sino la conversión de la Constitución en un texto vivo que acaba desligándose en muchos casos de la voluntad de su creador. La mutación en sentido estricto se produce cuando quedan obsoletos preceptos constitucionales o cuando, por una práctica abiertamente contraria al tenor literal del texto constitucional, se cambia el significado estricto o literal de un precepto de la Constitución. Estas auténticas mutaciones no son admisibles en una Constitución supralegal garantizada por la existencia de una justicia constitucional, cuyas principales funciones residen en interpretar la Constitución y evitar que los poderes constituidos adopten normas o prácticas contrarias al texto constitucional.

\section{ALBERTO LÓPEZ BASAGUREN}

Se trata de una cuestión difícil de responder, desde mi punto de vista, porque es necesario tener en cuenta distintos elementos que pueden dirigir en sentidos diferentes.

La primera sensación que me sigue transmitiendo el Título $\mathrm{X}$ cada vez que lo leo es la de ser excesivamente complicado y rígido. Dos procedimientos diferentes; ambos de gran rigidez básica, pero con un procedimiento para la reforma total de la Constitución o de sus partes especialmente protegidas que parece casi imposible de superar, etc. Mi afirmación inmediata — irreflexiva — sobre la regulación de la reforma en nuestra Constitución sería negativa.

Sin embargo, creo que un análisis detenido de su significado obliga a matizar mucho — si no a modificar- esta primera impresión.

Una primera cuestión a valorar es la relativa a la existencia de dos procedimientos diferenciados; tanto en sí misma - ¿son necesarios dos procedimientos diferentes?como en los elementos que los diferencian - ¿es necesario que los dos procedimientos difieran en tantos elementos? - . La segunda cuestión a valorar es la relativa a la idoneidad de un procedimiento agravado de reforma tan exigente y difícil. La tercera, finalmente, se refiere a las cuestiones cuya reforma exige el cumplimiento del procedimiento agravado: ¿faltan o sobran?

Si analizamos los requisitos del procedimiento agravado (art. 168), lo que comprobamos es que exige la concurrencia de un consenso político casi tan mayoritario como el 
que respaldó el texto de la Constitución en las Cortes Constituyentes en 1978. En cualquier caso, cualquier reforma de la Constitución en la que sea exigible cumplir el procedimiento del art. 168 es imposible en la práctica, salvo coyuntura muy extraordinaria, si no existe acuerdo entre los dos grandes partidos, los dos partidos que aspiran a la alternancia en el Gobierno. Y esos dos partidos casi en cualquier situación — salvo drástico cambio del mapa político de estos casi treinta y cinco años- reúnen la mayoría suficiente para afrontar cualquier reforma de la Constitución.

Esta consecuencia me parece razonable. La Constitución, y su reforma, requieren un consenso de base de gran amplitud. Esto es lo que sucede muy mayoritariamente en nuestro entorno, con muy escasas excepciones. Y ese fue el amplio consenso que obtuvo la Constitución en su elaboración. Es comprensible que la Constitución exija para la reforma total de la Constitución o de las partes que el constituyente consideró tan esenciales del sistema como para asimilarlas a una reforma total un consenso similar al que se consideraba exigible en el momento del nacimiento de la Constitución.

En este contexto, aligerar el procedimiento para la reforma de aquellas partes de la Constitución que no se consideran tan identificativas como para asimilarlas a una reforma total, parece una manifestación de flexibilidad que aligeraría la rigidez del procedimiento de reforma.

Por otra parte, la exigencia de mayoría de $2 / 3$ en el Parlamento - en una o en las dos Cámaras, en los supuestos de Parlamentos bicamerales - es aplastantemente mayoritaria en nuestro entorno jurídico-político. No parece, por tanto, que la exigencia de esa mayoría sea un exceso de rigidez, comparativamente hablando; especialmente si tenemos en cuenta que en el procedimiento ordinario esa mayoría se atenúa a una mayoría de 3/5 — salvo en caso de discrepancia entre Congreso y Senado, en que vuelve a exigirse aquella en el Congreso- - La mayoría exigida, por tanto, no me parece fácilmente objetable.

Creo, en todo caso, que la extrema dificultad del procedimiento agravado de reforma constitucional no está en la mayoría exigida, sino en los demás requisitos del procedimiento. Es decir, la disolución de las Cámaras que proponen la reforma y su aprobación por las nuevas Cámaras salidas de las elecciones, por una parte, y el sometimiento a referéndum, por otra. Tanto uno como otro requisito tienen una relativamente amplia tradición en nuestro entorno, lo que quiere decir que parecen tener algún sentido. Pero uno y otro requisito no suelen darse simultáneamente en los sistemas constitucionales de nuestro entorno. En algún caso, incluso, el único requisito es la concurrencia de la mayoría de dos tercios en las Cámaras parlamentarias, sin disolución, etc., y sin referéndum. Es el caso de Alemania, en el que, en cualquier caso, la mayoría de dos tercios en el Bundesrat añade un consenso territorial muy significativo. Yo creo que es aquí donde habría que aligerar el procedimiento de reforma constitucional.

La mayoría de las Constituciones que imponen la disolución y posterior aprobación de la reforma son Constituciones de origen antiguo - aunque haya sido incorporado a algunas de las nuevas Constituciones del centro y este de Europa- que, a pesar de las numerosas e importantes reformas que han conocido, se consideran continuidad de la Constitución original (Países Bajos, Noruega, Suecia, etc.). Y en estos casos, la reforma de la Constitución no se somete a aprobación directa de los ciudadanos mediante referéndum. 
Por su parte, el referéndum aprobatorio solo se exige en algunos sistemas, como el helvético —en el que se requiere mayoría del pueblo y de los Cantones, pero en el que el procedimiento parlamentario de aprobación es el legislativo ordinario-, el francés o el austriaco — del que tomó el constituyente español la idea de los dos procedimientos con referéndum obligatorio en uno y potestativo en otro- - Pero en estos sistemas no se produce la disolución y aprobación en segunda constitución de la(s) Cámara(s); y solo en el caso austriaco se exige una mayoría cualificada especial. Otros sistemas, como Alemania, limitan el procedimiento a la aprobación parlamentaria, sin disolución.

En este contexto, creo que lo que parece más distorsionador y con menor funcionalidad democrática es la necesaria disolución de las Cámaras y aprobación de la reforma por las nuevas Cámaras, tras las elecciones. La aprobación por los ciudadanos a través de referéndum tiene mayor sentido. No creo que, en la situación de nuestro sistema político fuese conveniente eliminar la exigencia del referéndum. Pero, dado que la última palabra la va a tener el cuerpo electoral, quizás podría flexibilizarse la mayoría especial tan exigente requerida en ambas Cámaras. Aunque ésta es una cuestión más delicada, por la necesidad de garantizar que ninguno de los partidos «de gobierno» sea marginado del consenso en la reforma de la Constitución.

Consciente de estos riesgos - y de la falta de conveniencia de dar saltos excesivos, creo que sería conveniente reformar el art. 168- en el sentido de eliminar la exigencia de disolución de las Cámaras, celebración de nuevas elecciones y aprobación de la reforma por las nuevas Cámaras. Pero creo que se trata de una modificación de una trascendencia solo relativamente importante, por lo que debiera afrontarse dentro de un paquete mayor y más significativo de reforma de la Constitución. En caso de que se mantuviese ese requisito, creo que, como ocurre en los países en los que está así establecido, la práctica política podría suplir parte importante de las dificultades que plantea su existencia.

En resumen, considero que el procedimiento de especial rigidez del art. 168 condensa los elementos que son comunes en los procedimientos de reforma constitucional; especialmente, la exigencia de mayoría de 2/3 de la(s) Cámara(s) parlamentaria(s). En este sentido, su rigidez no es extraordinaria o excesiva. Pero al añadir otros elementos, como disolución y nueva elección de las Cámaras para su aprobación y sometimiento a referéndum, acumulando distintos requisitos procedentes de distintas tradiciones constitucionales, en las que esos requisitos no concurren de forma acumulada, el diseño final resulta excesivamente complicado y exigente. Considero que es en el terreno de estos otros requisitos en los que debiera aligerarse el procedimiento de reforma. Dicho esto, me parece positivo mantener los dos procedimientos diferenciados, aunque sea excepcional en las Constituciones de nuestro entorno y contribuya a dar una imagen de excesiva rigidez del procedimiento del art. 168, por comparación, más allá de lo real.

Tras lo dicho en las líneas precedentes, creo que la trascendencia de la cuestión relativa a las materias cuya reforma se reconduce al procedimiento del art. 168 queda un tanto atenuada, en la medida en que, sustancialmente, con uno u otro matiz, nuestro procedimiento agravado es, sustancialmente, el único procedimiento de reforma de la Constitución en casi todos los países de nuestro entorno, cualquiera que sea la materia o parte de la Constitución que sea objeto de reforma. Desde este punto de vista, el procedimiento agravado sería el procedimiento ordinario de reforma de la Constitución, 
mientras que la excepción estaría constituida por el procedimiento regulado en el art. 167, como una excepción a la regla. En este sentido, me parece que la revisión total de la Constitución debe formar parte de este procedimiento agravado y las partes de la Constitución cuya reforma se reconduce a este procedimiento son lógicas si tenemos en cuenta el contenido del consenso que alumbró la Constitución. No cabe duda de que el sistema de derechos sea consustancial al régimen constitucional establecido y en el Título preliminar están los principios que identifican el orden constitucional. Con ello se cubre lo que en algunos sistemas son las cláusulas de intangibilidad constitucional — aunque aquí no se trate de cláusulas de esta naturaleza-; que, en lo que a nosotros se refiere, debieran ser el derecho a la autonomía de las nacionalidades y regiones establecido en el art. 2 - aunque creo que debiera formularse de forma más acabada - y la Monarquía parlamentaria como «forma política del Estado», establecida en el art. 1.

En este sentido, creo que incluir el Título II (dedicado a la Corona) entre las partes de la Constitución cuya reforma debe ser tramitada por el procedimiento del art. 168 resulta, en estos momentos, innecesario.

Soy plenamente consciente de que se trata de un terreno que puede levantar susceptibilidades; y soy plenamente consciente de las condiciones del consenso constitucional, que mientras nos garantice la estabilidad democrática y no sea sustituido por otro consenso que garantice esa estabilidad en las mismas condiciones, cuando menos, asumo y defiendo plenamente. En el momento constituyente tenía sentido, por muchas razones que es ocioso detallar ahora, incluir el Título II, en la medida en que allí se hacían opciones que eran objeto de importante controversia o, incluso, de oposición de algunos sectores. Incluirlo entre los sectores más garantizados ante una hipotética reforma tenía sentido. Pero en estos momentos, solo hay un hecho significativo del consenso constitucional que exige esa garantía: la Monarquía parlamentaria como «forma política del Estado».

Al igual que en el ámbito de la autonomía territorial, es el principio lo que requiere especial garantía; no sus concreciones normativas. Eso es lo que ocurre con todas las Constituciones que incluyen cláusulas de intangibilidad en uno u otro ámbito: organización federal o forma republicana de gobierno. Ello permitiría afrontar reformas de disposiciones de detalle pudiendo eludir los problemas que plantea este procedimiento, como el que se plantea en España respecto a la precedencia del varón sobre la mujer en la sucesión a la Corona.

Por tanto, me parecen lógicas las partes de la Constitución cuya reforma se reconduce al procedimiento del art. 168, aunque considero que, tras el tiempo transcurrido desde la aprobación de la Constitución, la inclusión del Título II (Corona) entre esas materias es innecesaria, por estar ya cubierta por la garantía del art. 1, que establece que la Monarquía parlamentaria es la «forma política del Estado»; y es, además, inconveniente, pues dificulta la reforma de disposiciones que no son esenciales respecto al contenido del consenso constitucional sobre la Monarquía.

Finalmente, para concluir, no tengo ninguna duda sobre el hecho de que la falta de actualización de la Constitución, de su reforma en aquellas cuestiones que - parafraseando el art. 112 de la Constitución noruega- la experiencia ha enseñado que debieran haber sido reformadas, ha sido debida a la incapacidad de los partidos de llegar a acuerdos sobre el sentido de las reformas. Soy contrario al reparto generalizado de culpas, sin ma- 
tiz. Pero en esta cuestión no tengo duda de que los dos grandes partidos, los dos «partidos de gobierno» son, ambos, los responsables de esta parálisis. Porque este resultado es el producto de la confluencia, cuando menos, de actitudes de unos y de otros: la negativa cerrada a tocar la Constitución, sin atender a ninguna razón; la incapacidad de ver la necesidad de adaptación flexible de la Constitución como forma de adecuarla mejor a las exigencias de la realidad, reforzando su vitalidad y la adhesión ciudadana; la pretensión política de dejar a la oposición en los márgenes del sistema, etc. En este contexto, ha sido manifiesta la incapacidad de los dos grandes partidos para hacer posibles los consensos, tratando de extenderlos a otras fuerzas políticas, de forma que permitiesen abordar las reformas constitucionales convenientes. Con esta cultura política (casi) cualquier planteamiento de reforma constitucional resultaba ilusorio.

\section{ANTONIO LÓPEZ PINA}

El art. 168 se justifica tanto por la voluntad de preservar a todo trance la garantía de los derechos fundamentales como de la conciencia entre los constituyentes de la coyuntural impertinencia, en la fase inicial de la Monarquía parlamentaria (art. 1.3 CE), de dejar constitucionalmente abierto un posible cuestionamiento de la forma de gobierno. Estas palabras mías no deberían ser interpretadas como que hago almoneda de mi ideario republicano. Luis Gómez Llorente, en el Congreso de los Diputados, y, en mi condición de portavoz del Grupo Parlamentario Socialista, en el Senado, yo, expusimos nuestra esperanza, en que, en cuanto a su ejecutoria de futuro conforme a la Constitución, la Monarquía no maladministrara nuestro voto de confianza ${ }^{10}$.

No hay que excluir una crisis de la forma de gobierno cuando abdique el actual Monarca. Pero habida cuenta de los problemas de desigualdad que están fracturando la sociedad española y poniendo en candelero las condiciones materiales para el ejercicio de la libertad y para la democracia, me parece prematuro y aventurado por el momento proponer la salida del Título II del blindaje que comporta el actual art. 168.

3. Qué opina Vd. sobre el camino procedimental que siguió el primer Gobierno del Sr. Rodríguez Zapatero para instar ciertas reformas constitucionales? ¿Qué otra forma de preparar la reforma en términos políticos y técnico jurídicos le bubiera parecido más positiva?

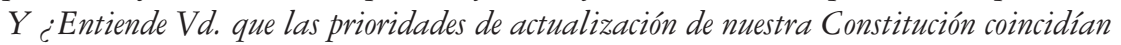
con las que aquel Gobierno sometió al informe del Consejo de Estado?

\section{ELOY GARCÍA LÓPEZ}

Estamos al final de toda una época y de un ciclo de la política española, y si se me apura mundial, y no resulta fácil juzgar una forma de proceder en política que si bien tiene en el anterior Gobierno y en las dos últimas legislaturas su mejor manifestación y su

10 Debate sobre el art. 1.3 de la Constitución, 18 agosto 1978, D. S. del Senado, nº 39, p. 1596. 
más acervada expresión, lo cierto es que encuentra ya importantes manifestaciones en épocas anteriores.

Cuando la política desaparece de las preocupaciones inmediatas de una sociedad interesada sólo por el éxito económico individual y los fulgores de la riqueza financiera, lo importante no son las decisiones para el mañana sino las impresiones. La eficacia de las normas y los valores de futuro ceden su lugar a los efectos y a las impresiones. Todo se presenta como histórico y sin embargo, apenas dura unos días en la memoria colectiva. Los hombres no influyen sobre los hechos sino que son los hechos los que arrastran a los hombres y a las sociedades. Todo eso ha sucedido en estos años y la forma de encaminar la iniciativa de la reforma y lo que se pretendía con ella se corresponde con esa clase de mentalidad.

Así pues, no creo que el primer gobierno Zapatero buscara con su consulta al Consejo de Estado, poner en marcha un proceso de reforma constitucional en determinados temas sensibles principalmente de naturaleza electoral. No había en su acción una conciencia sobre la necesidad de la reforma, sobre la urgencia o conveniencia de crear un nuevo marco estable institucional. El único propósito de aquella iniciativa era producir un efecto. Introducir una pieza en el debate político, en un instante en que todo indicaba que los problemas de la representación empezaban a calar en la opinión. Pero pasado el instante, la necesidad se desvaneció y el gobierno se olvidó de un informe que ya no le servía para agitar la política.

Hay dos formas de entender la Política, la tradicional en la que los intereses construidos desde opciones ideológicas se enfrentan a través de personas organizadas en partidos, y la actual, la de la época que ahora está concluyendo en la que el conflicto es por el poder y no por lo que se puede hacer con y desde él, en la que todo es soft, en la que no hay ideologías, en la que los intereses se esconden y queda sólo como motivo de debate argumentos fútiles, problemas formales, cuestiones triviales que aunque puedan ser objetivamente importantes resultan subjetivamente degradadas por gobiernos deseosos de presentarse ante su mercado de votantes con una sonrisa en los labios. En este marco, cuestiones de tanta trascendencia política de fondo como son las referidas a la organización de la representación, resultan incómodas y aunque puedan ser planteadas momentáneamente, muy pronto pasan al olvido. Trataré de extenderme algo más al respecto en la contestación a la cuestión $5^{\circ}$, pero en lo que hace al Informe del Consejo de Estado, los hechos nos demuestran que el Gobierno no tenía ningún interés real en tomar conciencia de posibles soluciones a problemas que no le inquietaban en absoluto. Y no estoy haciendo un juicio moral, sino sociológico. Cuando no hay Política, los verdaderos debates políticos no interesan, son sistemáticamente eludidos. Sólo hay poder, intereses y actores de teatro. Los dos primeros tratan de ocultarse, el tercero busca dar que hablar, pero siempre de temas intrascendentes, de fenómenos sociales ante los que se comportan como un ser bueno, compasivo, capaz de suscitar las simpatía de sus compradores-electores. ¿Qué tiene que decir en este escenario la reforma electoral? Tal vez interese a este respecto únicamente el tema de la sucesión a la Corona, pero más en su lectura frívola, es decir como espectáculo banal que como problema constitucional serio. Y en España la Corona es una cuestión políticamente clave para el futuro, porque la legitimidad del actual titular es más carismática que histórica, y ello encierra un grave riesgo para el heredero porque los carismas no se heredan. 


\section{JUAN CARLOS GAVARA DE CARA}

La Modificación del art. 2.3 de la Ley Orgánica del Consejo de Estado (LO 3/2004) permitió que dicho órgano participara en la realización de estudios, informes y directamente propuestas de reforma constitucional (o de leyes que se consideraban importantes a criterio gubernamental), es decir, se pretendía dar un carácter técnico a las propuestas de reforma constitucional para evitar que las iniciativas gubernamentales en la materia tuviera un carácter político y, por lo tanto, partidista desde un inicio. Esta perspectiva técnica obligaba a que los estudios, informes y propuestas no fueran excesivamente profundos por lo menos desde el punto de vista político, si de verdad se pretendía otorgar una relevancia técnica al informe o a la propuesta que surgiera del Consejo de Estado. En todo caso se pretende obtener una opinión fundada, autorizada, independiente y al margen de la opinión del Gobierno o de su actuación política, a pesar de que el propio precepto alude al hecho de que el Consejo de Estado debe valorar los aspectos de oportunidad y conveniencia de la reforma. La finalidad última de esta opinión independiente del Gobierno reside en que se facilite el consenso sobre el contenido, alcance y temática a tratar en la posible reforma constitucional.

Ahora bien para aplicar este procedimiento innovador se debe tratar de iniciativas gubernamentales, por lo que resulta sencillo obviar la realización del informe del Consejo de Estado cuando la reforma se tramite a través de iniciativas parlamentarias tal como ha sucedido en la reciente reforma constitucional del art. $135 \mathrm{CE}$, que como veremos presenta problemas de articulación técnica-jurídica con el ordenamiento constitucional y el resto del ordenamiento, sobre todo una valoración de su oportunidad y conveniencia, que precisamente era la finalidad a la que respondía la modificación de la Ley Orgánica del Consejo de Estado.

En todo caso, en mi opinión la realización de estudios sobre anteproyectos de reforma constitucional o de leyes importantes emprendido por el Consejo de Estado en colaboración con el Centro de Estudios Políticos y Constitucionales puede considerarse positivo, ya que la publicación de los informes en unión a los diversos estudios realizados intentaron resolver de forma adecuada y convincente los diversos encargos realizados por el Gobierno. Una cuestión distinta es si los encargos se formulaban correctamente, ya que a menudo el planteamiento de carácter restrictivo y encasillado en unos parámetros no siempre fáciles de resolver, limitaba las posibilidades de realización de estudios con una perspectiva más profunda sobre su oportunidad y conveniencia. Además dichos encargos gubernamentales no siempre tenían carácter técnico, es decir, planteaban una complejidad de orientación política que hasta cierto punto no correspondía resolver al Consejo de Estado. Desde otra perspectiva, lo cierto es que no hay reforma sencilla. Basta pensar en las implicaciones en otros preceptos constitucionales que tenía mencionar a las Comunidades Autónomas en la Constitución, que evidentemente ya estaban creadas y consolidadas. En este sentido, la realización de un estudio técnico, incluso pluralista en sus tendencias y perspectivas, me parece una vía correcta para el estudio de las posibles reformas constitucionales. Un análisis exclusivamente político no determinaría las implicaciones para el resto del texto constitucional, para el ordenamiento jurídico interno o el de la Unión Europea, es decir, las repercusiones técnicas, importantes para valorar la oportunidad y conveniencia, no están presentes en un análisis exclusivamente político. 
Otras vías para elaborar anteproyectos de reforma constitucional pueden ser susceptibles de ser utilizadas con tanta efectividad como el anteriormente analizado, ya que tampoco es inadecuado recurrir a una comisión de sabios y/o técnicos para articular un texto con el que se pueda facilitar el consenso de las fuerzas políticas, aunque dudo que dicho informe obtuviera una aceptación mejor que el elaborado por el Consejo de Estado, aunque sí una mayor libertad para elaborar sus resultados.

Conectando con este último aspecto, sí que me parece conveniente resaltar que el Consejo de Estado ha sido criticado, de forma velada, por haberse extralimitado en el contenido sustancial de su informe al pronunciarse sobre aspectos no planteados por el entonces Gobierno e ir más allá de su petición. Restringir y limitar un informe de esta naturaleza a la voluntad estricta del solicitante no siempre es fácil, ya que la cohesión, sistemática y realidad constitucional es amplia y se requiere cierto margen de libertad para poder valorar los distintos ángulos y consecuencias de una reforma constitucional.

La voluntad del Gobierno en la solicitud del informe del 2004 era realizar una reforma de mínimos y con trascendencia en apariencia solamente formal, salvo la reforma del Senado, pero que afectaban a los principios estructurales, sin que el resultado se pudiera consensuar en su contenido ni entre las fuerzas mayoritarias. En todo caso, dicho proceso nos permite deducir que la puesta en marcha del proceso de reforma constitucional requiere que con carácter previo estén de acuerdo los dos principales partidos mayoritarios, ya que sin ese mínimo consenso ni siquiera se pueden materializar las iniciativas.

\section{ALBERTO LÓPEZ BASAGUREN}

Creo que el planteamiento por el Gobierno de la necesidad de reformar la Constitución tiene un aspecto positivo en el hecho mismo de poner la reforma constitucional sobre la mesa.

Respecto a las cuestiones planteadas por el Gobierno para una reforma constitucional coincido ampliamente con que son ésas las cuestiones que se deben abordar prioritariamente; pero discrepo con los términos en que planteó alguna de ellas.

El acuerdo del Consejo de Ministros (2005) por el que solicitó Informe del Consejo de Estado sobre la propuesta de reforma establecía, como es sabido, cuatro elementos. Coincido plenamente respecto a la necesidad de plantear la reforma de la Constitución en tres de esas cuestiones en la forma que lo hace el Gobierno. La reforma del art. 57.1 de la Constitución, en el que se establece la preferencia, en el mismo grado, del hombre sobre la mujer en la sucesión al trono debe ser abordada cuanto antes; y creo que no es necesario extenderse demasiado en su justificación. La igualdad entre hombre y mujer en el acceso al trono no está generalizada en las Monarquías parlamentarias de nuestro entorno. Pero creo que es una exigencia de los tiempos a la que España, con un sistema democrático con menor tradición histórica y, sobre todo, con una Monarquía menos enraizada en el sentimiento de los ciudadanos, tiene mayor necesidad de adaptarse que otros países con Monarquías que gozan de una mayor legitimación popular y que son, en consecuencia, menos vulnerables, en la crítica, a determinadas deficiencias o anacronismos. 
También me parece acertado plantear la reforma constitucional para incorporar, de forma expresa, el proceso de construcción europea a la Constitución. El impacto de este proceso sobre la posición y el significado de las Constituciones de los Estados es tan profundo que es necesario, en mi opinión, establecer en la propia Constitución la decisión de participar en el proceso de integración europea (durante tantos años realizado, en gran medida, a espaldas de los ciudadanos) y precisar en ella las repercusiones que la integración europea provoca en el sistema jurídico-político del Estado, que se ha ido imponiendo en la práctica, quedando la Constitución como convidado de piedra.

Finalmente, comparto la necesidad de afrontar la reforma del Senado, para que responda más adecuadamente a la definición constitucional de «Cámara de representación territorial», según la célebre frase del art. 69.1. Se trata de una pretensión cuya necesidad se ha convertido ya en un tópico en el debate político y doctrinal, pero que parece condenado a no afrontarse nunca.

Lo que, por el contrario, me parece decepcionante es la propuesta de reformar la Constitución para incluir la denominación de las Comunidades Autónomas. Creo que, como explicaré más adelante de forma más pormenorizada, la reforma de las disposiciones constitucionales relativas a las Comunidades Autónomas (Título VIII) es la tarea pendiente más importante que tiene ante sí nuestra Constitución. Dentro de esa tarea no creo que la inclusión de los nombres de las Comunidades Autónomas sea la mejor forma de afrontarlo. Por supuesto, con plena conciencia de que no se trata de una cuestión meramente nominativa, sino de la fijación en la Constitución de las Comunidades Autónomas que integran nuestro Estado autonómico.

Por tanto, coincido con que las cuestiones que planteó el Gobierno son las cuestiones que deben ser abordadas de forma prioritaria en la perspectiva de la reforma constitucional, con la importante salvedad relativa al planteamiento de la reforma en lo que se refiere a las Comunidades Autónomas. Eso no significa, sin embargo, coincidencia con las prioridades establecidas por el Gobierno. Soy consciente de que la cuestión de la sucesión de la Corona tiene su propia urgencia; y, también, de que puede haber consideraciones de oportunidad política en la forma de plantear, finalmente, una concreta reforma constitucional. Pero creo que no es bueno ir apilando distintas reformas de la Constitución, al mismo tiempo, cuando menos, en el inicio del proceso y en su debate y elaboración. Creo que cada cuestión debe tener su propio desarrollo, debe madurar adecuadamente, analizarse y elaborarse de forma idónea, con independencia de que, finalmente, puedan tramitarse de forma conjunta o separada una, dos o más cuestiones a reformar, de acuerdo al consenso político alcanzado y a las consideraciones de oportunidad política sobre el procedimiento.

Esto hace referencia a la cuestión relativa al procedimiento seguido por el Gobierno.

En relación con esta cuestión, creo que es necesario referirse a dos aspectos diferentes: la gestión política de la pretensión de reforma y el soporte jurídico que se ha buscado para la misma. Parece muy conveniente recurrir al Consejo de Estado, como hizo el Gobierno, para analizar y determinar qué formulaciones técnicas son las más adecuadas en cada caso; máxime a la vista del Informe elaborado por el alto órgano consultivo (2006), que, sin duda, es de gran valía. Pero un proceso de reforma constitucional es, por encima de todo y antes que nada, un proceso político, cuyo éxito o fracaso se juega, en primer lugar, en el terreno político. Es en ese terreno en el que, en mi opinión, la pro- 
puesta de reforma murió muy pronto; probablemente, en el mismo momento de su nacimiento o, en todo caso, muy poco después.

Es muy posible que el Partido Popular no hubiese aceptado, en ningún caso, entrar en un proceso de debate y trabajo que pudiese llevar a un acuerdo sobre la reforma - que tendría que haber tratado, además, de incluir a otros partidos-. Pero la formalización por parte del Gobierno de una propuesta de reforma en los términos en que lo hizo, como una propuesta propia - en lugar de que fuese el resultado de un trabajo en busca de un consenso de base- , y la solicitud de informe al Consejo de Estado en ese momento inicial, llevaban a una propuesta cerrada, que, prácticamente, impedía que apareciese como el resultado de un trabajo conjunto - y de consenso- de las fuerzas políticas. A ello hay que añadir el clima de confrontación política sin cuartel entre los dos grandes partidos que se desarrolló ya durante aquella primera legislatura del Sr. Zapatero en la Presidencia del Gobierno. En esas condiciones, la propuesta de reforma constitucional estaba muerta sin remedio.

Los partidos de oposición pueden acabar haciendo imposible un proceso de reforma constitucional; pero la responsabilidad del Gobierno es plantear las cosas de forma que el éxito sea posible. La forma en que el Gobierno Zapatero planteó la propuesta de reforma constitucional abocaba a ésta, sin remedio, al fracaso y limitaba su valía al ámbito de la confrontación partidista. El Gobierno no tuvo la altura política que requería afrontar con alguna posibilidad de éxito nuestra primera reforma constitucional de importancia. Su éxito hubiera roto el tabú sobre la reforma de la Constitución y hubiese permitido plantearse otras reformas que necesita la Constitución, sin seguir instalados en la parálisis.

Creo, en resumen, que las propuestas de reforma constitucional —las que de verdad son un reto para nosotros, al margen de las que sean transposición de decisiones externas o ajenas - solo tendrán posibilidad de éxito en el futuro si se plantean en una dinámica abierta de consenso desde el inicio, con mucha discreción en los momentos iniciales, huyendo de cualquier tentación o sospecha de utilización en la confrontación partidista, que puedan aparecer como resultado de un trabajo conjunto entre las fuerzas políticas y resultado del consenso entre ellas. Es en ese contexto en el que tiene sentido un idóneo soporte técnico, como el que el Consejo de Estado aportó con ocasión de la consulta planteada por el Gobierno.

\section{ANTONIO LÓPEZ PINA}

La corrección esencial del procedimiento en la reforma de $1992^{11}$, contrasta justo con la insensibilidad para la Constitución y la teoría constitucional mostrada, en la reforma del 7 de septiembre, por el Presidente del Gobierno y por el líder de la Oposición mayoritaria.

Aún cuando el Dictamen del Consejo de Estado no me satisficiera plenamente, en conjunto me pareció correcto — se limitó a responder a las cuestiones planteadas por el Gobierno-

11 Pleno del Congreso de los Diputados, de 13 de julio de 1992 y publicación en Boletín Oficial del Estado, de 28 de agosto de 1992. 
4. ¿Nos puede dar su opinión sobre los aspectos de las partes dogmática y orgánica de la CE cuya reforma considera más importante o urgente, sin perjuicio de poder extenderse más adelante en las materias referidas en las tres preguntas siguientes?

\section{ELOY GARCÍA}

Creo que hay una cuestión previa a cualquier pronunciamiento sobre un cambio constitucional que aspire a introducir vía reforma, mejoras en la Constitución: saber qué está sucediendo en el mundo actual. Esclarecer aquello que Burke llamaba las causas del actual descontento. Esto es, hay que precisar si el momento en que vivimos es de crisis o de declive de las instituciones constitucionales.

La crisis supone una lucha entre dos ideas de signo opuesto, la decadencia un desgaste en su eficacia real de un mecanismo, de una institución o de una figura jurídica. Tal y como parecen estar las cosas, nuestro problema, y no sólo el de España sino de las hasta hace poco llamadas sociedades occidentales, está en el decaimiento de nuestras instituciones, no en la posibilidad de que sean substituidas por otras que en el momento no se vislumbran en el horizonte como alternativa. Se trata por tanto, de regenerar la democracia y los derechos, de recuperar y corregir sus disfunciones. Para ello hay que replantearse el papel de la propia Constitución como mecanismo regulador de la gobernanza política, y posiblemente abrir el camino a un enfoque de la vida política en el que los contrapesos políticos tengan un papel que ahora en principio sólo se atribuye a lo jurídico. En materia de libertades y derechos fundamentales, convendría replantearse la dimensión estrictamente subjetiva de los mecanismos de protección y tratar de garantizar una eficacia real de los mecanismos procesales. Tenemos muchos derechos garantizados, incluida la tutela judicial efectiva. Pero quien se enfrenta a un proceso sabe muy bien que nada más difícil que obtener una reparación del daño causado. Parece como si la finalidad del proceso fuera el proceso en sí y no la obtención de un resultado material que restaure el bien lesionado. Por otro lado, han aparecido otra clase de derechos que difícilmente se encuentran tutelados con el actual marco normativo, como los derechos relacionados con el hecho informático o la movilidad, o el acceso a los nuevos servicios públicos imprescindibles para garantizarse un mínimo vital esencial. Estos derechos no se encuentran en muchos casos recogidos en la Constitución y admito que no fuera necesario introducirlos ahora. Pero si resultaría conveniente revisar los mecanismos de garantía que pretenden asegurarlos y sobre todo, establecer un marco claro dentro del cual, el usuario, mediante el correspondiente desarrollo legislativo, pueda ver reconocido su derecho al acceso - y subrayo la palabra acceso porque está empezando a ser clave para los juristas - a unas prestaciones sin las cuales no puede literalmente sobrevivir. Y esto reza para el agua, el medioambiente, la vivienda, la electricidad y con todo aquello que hace años Forsthoff llamó procura existencial.

\section{JUAN CARLOS GAVARA DE CARA}

Una pregunta de esta naturaleza puede implicar un riesgo de desmesura en contenidos y argumentaciones, en todo caso señalaré materias o normas que deberían abordarse 
constitucionalmente o modificaciones necesarias por un mal funcionamiento, que no se relacionen con las cuestiones concretas planteadas en las siguientes preguntas (sistema electoral de las Cortes Generales, sistema autonómico, constitución económica y relaciones con la Unión Europea). Aunque en muchas ocasiones se trata de problemas que implican una necesidad de corrección de la norma constitucional por el paso del tiempo, la mayoría de la problemática responde a la lógica de que el legislador no ha sabido resolver el problema por incapacidad o falta de voluntad política, por lo que resulta mejor abordarlo desde una perspectiva constitucional para someter a límites y mandatos a los poderes constituidos, o debido a que en la aplicación práctica de las disposiciones constitucionales se han generado distorsiones que requieren corrección. En todo caso, debo resaltar que mis comentarios serán pinceladas sobre temas que merecerían en muchos casos una encuesta propia por lo que no se argumentará en exceso y en muchos casos se deben leer entrelíneas y, en primer lugar, remarcaré que estoy de acuerdo con el Informe del Consejo de Estado del anteproyecto de reforma constitucional elaborado en la primera legislatura del Gobierno Rodríguez Zapatero por lo que no insistiré en esta sede en la necesidad de incluir en la Constitución la supresión de la preferencia del varón en la sucesión al trono, la recepción constitucional del proceso de construcción europea, la inclusión de la denominación de las Comunidades Autónomas y la reforma del Senado, salvo algún comentario incidental.

En el sentido señalado, sinceramente creo que, en primer lugar, se debería adoptar una regulación constitucional en torno a los temas de corrupción política para evitar que puedan ser regulados exclusivamente por el legislador sin ningún tipo de directriz o prescripción constitucional. Las regulaciones legales en materia de financiación política y electoral, así como las normativas en materia de delitos de carácter político o electoral, han generado una concepción y sensación de impunidad que exigiría una respuesta constitucional que eventualmente puede implicar facilitar las investigaciones judiciales, la prohibición de conceder indultos en dicha materia o la modificación de la regulación de la inmunidad parlamentaria con una prohibición expresa del efecto de sobreseimiento libre en caso de denegación del suplicatorio y una regulación estricta del procedimiento de resolución parlamentaria de su concesión o denegación con inclusión expresa de una motivación en la resolución.

En relación a la Corona se hace necesaria también una actualización del Título clarificando desde la Constitución el Estatuto de la Familia Real para evitar dudas o la realización de corruptelas sobre su alcance y régimen de incompatibilidades, limitando una extensión excesiva de privilegios y regulaciones singulares. La Casa del Rey como el resto de las administraciones debe someterse al mismo régimen de control externo para que no se generen dudas sobre el cumplimiento de la legalidad ordinaria en las aplicaciones presupuestarias, lo cual debe ser regulado necesariamente en la Constitución.

Entre los órganos de carácter jurisdiccional se debe mejorar los sistemas de nombramiento y de renovación de los miembros. El Consejo General del Poder Judicial no creo que deba modificar sus funciones, pero sí establecer un sistema que no sea tan condicionado en la designación de los miembros por las Cortes Generales o por las asociaciones profesionales que no siempre rigen sus actos con independencia e imparcialidad de intereses. En este sentido, seguramente no se requiere realizar una reforma constitucional, sino legal a partir del que fue el primer modelo de regulación de este órgano, 
ya que las razones que originaron en su día su modificación seguramente ya no se plantean en la actualidad. Constitucionalmente sí que me parece más necesario regular qué pasa si no se renueva por una falta de decisión parlamentaria, ya que hay que darle una solución al margen del legislador, que no puede consistir en la mera prórroga del mandato sine die.

En relación al Tribunal Constitucional me parece correcto que se pueda ampliar el número de magistrados a 15 para articular tres salas de trabajo, que permitiría aliviar el trabajo acumulado (a pesar de la mejora que supuso la última reforma, aún los plazos de resolución en materia de control de constitucionalidad y conflictos de competencia son amplios) y adoptar decisiones sin necesidad de recurrir al voto de calidad por el número impar de miembros. Para evitar la posibilidad de pactos entre grupos políticos mayoritarios se propone recurrir al nombramiento singularizado, uno a uno de los magistrados, que ejercerían su mandato de forma inamovible hasta los 75 años. Evidentemente se deberá modificar el procedimiento de propuesta y designación de candidatos, lo que puede conllevar que sean propuestos por el Gobierno y designados por el poder legislativo en su totalidad los miembros, seguramente mejor por una Comisión Mixta Congreso-Senado especializada en la materia o en la designación de miembros de órganos constitucionales. En cuanto a procedimientos desde un punto de vista constitucional solo me parece importante resaltar que se debe recuperar el recurso previo de inconstitucionalidad para control de los Estatutos de Autonomía sobre todo si sigue en su función de norma de articulación de competencias, que dicho sea de paso creo que se debería suprimir, y, desde otra perspectiva, introducir un control sobre los procedimientos de aplicación de la reforma constitucional.

En materia de derechos fundamentales y orden jurisdiccional probablemente se haya llegado al momento de regular mejor el anclaje del amparo ordinario y sus relaciones con el amparo constitucional. Seguramente se hacen necesarias nuevas regulaciones sobre el amparo ordinario que fuercen su especialización en función del derecho fundamental concreto en el que sea aplicable, lo que puede implicar reflexionar sobre la necesidad de una creación de un nuevo orden jurisdiccional en materia constitucional, como ámbito material especializado en derechos fundamentales y otras materias de relevancia constitucional como el Derecho electoral en general o conflictos de competencia entre Estado y CCAA. Este orden jurisdiccional en un inicio se debería limitar a una sala en los Tribunales Superiores de Justicia y otra en el Tribunal Supremo, acumulando los casos por la relevancia de la materia constitucional (incluidos los casos en que solo se recurrieran decisiones judiciales por infracción de derechos fundamentales específicos como la tutela judicial específica o las garantías del proceso debido), limitando sus enjuiciamientos a revisiones de órganos jurisdiccionales inferiores o a enjuiciamientos directos.

La regulación constitucional del Título Primero de la Constitución también requiere un mejor adecuación al tiempo actual, aunque en determinados derechos fundamentales se debe emprender con mayor urgencia como puede ser la regulación de la problemática de las nuevas tecnologías, de la libertad de expresión y derecho de información para recoger nuevos contenidos y adecuar a la realidad actual audiovisual y digital, los ámbitos de la bioética y la biotecnología, así como el derecho de huelga, entre los clásicos, por citar algunos ejemplos más evidentes. Del mismo modo se podrían suprimir algunos de- 
rechos que han tenido relevancia o que han desaparecido las causas que los motivaron como la prohibición de los tribunales de honor (art. $26 \mathrm{CE}$ ) o incluso el derecho de petición con un escaso recorrido actual.

En cualquier caso, estos criterios son meras generalidades sobre problemas grandes o pequeños que desde una opinión personal considero que debe ser objeto una respuesta constitucional, pero entiendo que los principios estructurales de nuestra Constitución están bien seleccionados y que siguen siendo el eje del acuerdo constitucional por lo que deben permanecer a largo plazo y que, en este contexto, las modificaciones solo deben afectar exclusivamente a preceptos concretos.

\section{ALBERTO LÓPEZ BASAGUREN}

Sustancialmente, ya he respondido en la pregunta anterior. Creo que debemos ir fijando con prudencia las reformas que necesita la Constitución; e ir afrontándolas sin pausa pero sin prisa. Por tanto, no debemos caer en la tentación de hacer una nueva Constitución. Y, mucho menos, la Constitución que cada uno de nosotros quisiera, tirando por la borda el gran éxito de la Constitución de 1978: su capacidad de integración y el logro de un consenso equilibrado que incorporó gran parte de lo mejor de la tradición democrática europea. Las reformas que se planteen no pueden volver sobre los elementos básicos del consenso alcanzado en 1978. Pero deben afrontar los retos planteados por los cambios producidos en nuestra sociedad en estos años y tratar de adecuar la Constitución a los problemas que se han puesto de manifiesto en el funcionamiento del sistema político y su desarrollo. Tampoco podemos ir acumulando cuestiones que requieren reforma y tratar de hacerlas todas a la vez, sin la reflexión y la maduración necesarias; por eso es tan negativa la parálisis de estos años.

Situadas las cosas en estos términos, creo que las cuestiones planteadas por el Gobierno Zapatero en 2005, con las matizaciones que he realizado en la respuesta a la pregunta anterior, son las más urgentes, son más que suficientes y plantean una tarea, sobre todo política, muy ardua, que requiere tiempo y esfuerzo y, por encima de todo, acierto en su gestión.

Considero que tenemos dos cuestiones especialmente importantes pendientes de una adecuada regulación constitucional, aunque su repercusión política y su trascendencia en el futuro del sistema político español son de diferente naturaleza. Por una parte, la adecuada regulación constitucional del sistema autonómico, a la que está vinculada, desde mi punto de vista, la reforma del Senado; y, por otra, la relativa al adecuado engarce de la integración europea en la Constitución. Las demás reformas me parecen, si puede decirse, «circunstanciales», como la relativa a la eliminación de la precedencia masculina, en el mismo grado, en la sucesión a la Corona. Y sería bueno que se fuese creando una cultura y un clima político que permitiese afrontar las reformas de forma ágil, para eludir el riesgo de que terminen por enquistarse, pudriéndose. A estos efectos, es importante la gestión política de las reformas «circunstanciales», porque puede crear un clima favorable, de entendimiento y confianza entre los partidos políticos que permita encarar el debate sobre otras reformas de más calado en condiciones adecuadas. 


\section{ANTONIO LÓPEZ PINA}

\section{Título Preliminar}

a) Democratización de los partidos políticos, dentro de un régimen parlamentario en la tradición europeo — continental — excluyente de las elecciones primarias de candidatos, propias más bien de regímenes presidencialistas y de institutos extraños a nuestra democracia representativa, sin ir más lejos.

\section{Parte dogmática}

b) Una cláusula vinculante de lealtad constitucional, que complemente la fuerza normativa de la Constitución (art. 9.1 CE)

c) Una garantía reforzada del derecho al trabajo, del derecho a la negociación colectiva y de los derechos sociales del trabajador

d) La Constitución debe contener garantías, mayores a las actuales, tanto de la enseñanza como de la sanidad públicas

e) La garantía de la universalidad de acceso a la información y a las comunicaciones

f) Junto la garantía de los derechos fundamentales (art. 53 CE) y de la igual libertad (arts. 9.2; 33; $128 \mathrm{CE}$ ) requieren, como condición sine qua non, de un lado, el desarrollo del principio de justicia fiscal (art. $31 \mathrm{CE}$ ), sin excepciones por clase social o Comunidad Autónoma; de otro, el aggiornamento constitucional de las relaciones entre la Iglesia Católica y el Estado (art. 16 y art. 27 CE en conexión con art. 16 CE)

II Parte orgánica

g) Orden territorial. Proclamación del Estado federal y reforma del Senado, como Cámara de representación territorial. Desde los orígenes de la Constitución tenemos los españoles pendiente la proclamación para nuestro Orden territorial del Estado federal, en contra tanto de los filibusterismos de las burguesías vasca y catalana como del nacionalismo castellano.

h) Redistribución de competencias. Tras la experiencia de funcionamiento del Estado de las Autonomías, de un tercio de siglo, la enseñanza general básica y la política universitaria y de investigación deben ser devueltas a la Administración central

i) La autonomía municipal requiere una profunda reforma, que comprenda asimismo la garantía de una dotación financiera suficiente

j) Reforma de las cláusulas constitucionales de mandato al legislador electoral, al servicio del Estado federal

k) Reforma del Consejo General del Poder Judicial

\section{Relaciones internacionales}

1) Las condiciones constitucionales de nuestra incorporación a la Unión Europea, en términos de la determinación constitucional del Derecho europeo ${ }^{12}$.

12 Vid. LÓPEZ PINA, A., La determinación constitucional del Derecho comunitario, en Libro-Homenaje a Luis Díez-Picazo, Civitas, Madrid, 2002; id. Europa, un proyecto irrenunciable, Madrid: Dykinson, 2004; id. La 
5. ¿Aconsejaría abordar la reforma de la composición (incluido, si así lo estima conveniente, el sistema electoral) del Congreso y del Senado? ¿Y de sus funciones básicas?

\section{ELOY GARCÍA}

Creo sinceramente que los problemas de la democracia son demasiado profundos e importantes como para intentar acometer su reforma acudiendo a soluciones de ingeniería electoral. Ese fue el gran error en que incurrieron los italianos tras tangentopolis. Y lo han pagado muy caro, les ha llevado ni más ni menos que a perder una generación entera. Para regenerar la democracia hay que volver a la Política. Recuperar el papel de las ideas en el debate colectivo, y conseguir que lo que a todos afecta cuente con la participación de todos. Ése es el verdadero quid del tema. La Política no puede ser un teatro vacío en el que sólo se producen efectos y no hay más que lucha por el poder entendido como mando o como dominación.

Cuestión aparte es el papel que en democracia corresponde desempeñar a los partidos; conviene no olvidar lo que dice el artículo $6^{\circ}$ al respecto y preguntarse si se cumple. La desaparición de las ideologías tras la Caída del muro, ha arrastrado consigo a su criatura orgánica, a la institución social que tenían como misión hacerlas realidad, los partidos políticos. Los partidos son hoy fantasmas que como intuyera tempranamente Kirchheimer, en la práctica ya no tienen más objetivo que conquistar y mantenerse en el poder. En un poder al que no aportan ideas, en un poder que dice sistemáticamente sí a las opciones más opuestas, porque proceder de otra manera equivale a perder votos. La consecuencia es que no se gobierna. Que los ejecutivos difícilmente toman decisiones, y menos si sospechan que van a resultar polémicas. De lo que se trata es de conseguir sumarse a la prosperidad general que hasta hace poco fluía constantemente desde los mercados y desde la virtualidad financiera. La lógica del poder ha terminado desplazando a la lógica de la Política, y tener ideas en cuestiones públicas sólo depara problemas. Incluso las mejores mentes se dedican a la procura del lucro privado. La Política parece como un mundo de prestidigitadores, donde reina una suerte de ley de Gresham, un oficio profesional articulado al margen de cualquier principio, de cualquier valor, para el cual el único atributo imprescindible era ser un buen actor... Es impresionante leer las memorias de dos generaciones de premier laboristas británicos a los que apenas separan veinticinco años. Harold Wilson en sus memorias llamadas Informe personal (1971) desgrana uno a uno todas las circunstancias y detalles de las importantes decisiones que tomó en su época sin explicar si era soltero o casado; Tony Blair en su A Journey, My Political Life (2010), nos explica cuáles eran sus impresiones, cómo era su mujer, sus hijos, sus sentimientos... pero apenas dice nada de sus convicciones, de lo que hizo para traducirlas en decisiones, si es

Constitución territorial de España. El Orden jurídico como garantía de la igual Libertad, Marcial Pons, Madrid, 2006; id. Los Tratados de la Unión Europea, Marcial Pons, Madrid, 2007; Id., Los Intereses Generales, mandato constitucional, Real Academia de Jurisprudencia y Legislación, Madrid, 2007; id. Die Anwendung des gemeinschaftsrechts in Spanien unter besonderer Berücksichtigung der gemeinsamen Verfassungsüberlieferungen der EU-Mitgliedstaaten: Öffentliche Dienstleistung der Elektrizitätsversorgung versus freier Kapitalverkehr, in: Öffentliches Recht im offenen Staat. Festschrift für Rainer Wabl zum 70. Geburtstag APPEL, I; HERMES, G; SCHÖNBERGER, Ch Hrsg., Duncker \& Humblot, Berlín, 2011. 
que hizo algo... Y sin embargo, también en los años de Blair se tomaron decisiones claves que afectaron a la paz y a la guerra, a la prosperidad y al bienestar económico de las generaciones que vendrían después. Sólo que la política dejó de ser una materia pública y pasó a ser el negocio privado de la reducida oligarquía que en realidad toma las decisiones en los sistemas democráticos, en medio de la indiferencia general de una sociedad que ha sustituido la preocupación por las ideas, por la ambición de hacerse rica.

Así las cosas es muy posible que determinadas reformas dirigidas a movilizar la política, a evitar la patrimonialización del poder y la perpetuación en las funciones públicas, ayuden en esa tarea. Pero nada puede sustituir a la voluntad de una sociedad que hace del autogobierno el primero de sus deberes. Participar en Política debe ser entendido como un deber, no como un derecho. La libertad política tiene que preceder a la libertad individual-subjetiva, a los derechos de disfrute. La libertad política siempre debe estar condicionada a la intervención de nuestros conciudadanos y en eso —además de otras muchas cosas - se diferencia de la libertad subjetiva que genera un goce individualizado. En resumen, la tarea del momento democrático actual pasa por una coimplicación cívica que sirva de remedio al vaciamiento político de los partidos. Para eso hay que modificar muchas más cosas que el sistema electoral o las circunscripciones. Ni las listas abiertas, ni las circunscripciones uninominales parecen estar en condiciones de aportar mucho en esta dirección si no se asegura la continuidad de la acción política más allá de la jornada electoral. Esa era la labor de los partidos. Esa debe ser la labor de los ciudadanos si aspiran a conservar la democracia. Por otro lado se impone la necesidad de reforzar la responsabilidad de los gobernantes, pero no tanto a través de la articulación de mecanismos de control a posteriori, como mediante una adecuada conexión entre la acción política y la voluntad y el debate colectivo.

Tras la crisis de las ideologías, los grupos de poder han tomado el relevo a los partidos, a los que - y soy consciente de que no es muy habitual reconocerlo hoy en díatiene mucho que agradecer la democracia Europea y nuestro privilegiado modelo de Estado Social y de Derecho. Y es preciso recordar que en tanto las ideas no consigan llenar el vacío dejado por las ideologías, seguirán campando por sus respetos unos intereses que disfrazados por efectos virtuales continuarán presentándonos como trascendental y decisivo, lo que sólo es un efecto destinado a generar apariencias mientras se hurta el auténtico debate. Sin ideas no puede haber partidos, y sin partidos, entendidos de una forma diferente a cómo son hoy, la democracia en un mundo de masas se hace muy difícil, por no decir imposible.

\section{JUAN CARLOS GAVARA DE CARA}

En relación con aspectos más concretos vinculados al sistema electoral de las Cortes Generales, conviene recordar que la Constitución establece la duración máxima del mandato parlamentario, las características más importantes de la fórmula electoral, la determinación con mayor o menor precisión del número de miembros de los órganos, la circunscripción electoral, el número de electos por circunscripción mínimo o máximo según los casos o la determinación de los casos donde se produce por decisión constitucional la necesidad de una simultaneidad de la elección de los órganos legislativos. 
Estas decisiones constitucionales se articulan en relación con el sistema electoral del Congreso de los Diputados en torno a tres grandes ideas, en primer lugar, el establecimiento de un abanico mínimo y máximo para fijar el número de los diputados (entre 300 y 400 diputados); en segundo lugar, el establecimiento como circunscripción para las elecciones al Congreso de los Diputados de la provincia con la finalidad de que no se realizaran manipulaciones en el mapa electoral (la provincia era un territorio tradicional y se había sido utilizado como circunscripción en las elecciones del 15 de junio de 1977) y además se estableció una representación mínima inicial de electos por cada circunscripción (sin fijar su cuantificación que se remitía a la legislación electoral) y repartiendo el resto de los electos en proporción a la población; por último, se aceptó la introducción de la exigencia de un sistema de representación proporcional en el Congreso de los Diputados. Estas decisiones son las que han permitido caracterizar este sistema electoral como proporcional que produce unos efectos mayoritarios lo que ha condicionado nuestro sistema de partidos en torno a dos grandes opciones a nivel estatal, permitiendo además que se articulen como opciones mayoritarias en algunas Comunidades Autónomas a los partidos nacionalistas. En cualquier caso, entre estas decisiones constitucionales, las que más han condicionado los efectos en la configuración del sistema de partidos y, en general, los efectos del sistema electoral, han sido las decisiones en torno a la circunscripción y la existencia en la misma de una representación mínima inicial.

Seguramente la problemática de la circunscripción electoral es más relevante en relación a los senadores de elección directa que necesariamente se deben conectar a la consideración del Senado como cámara de representación territorial. En realidad, la constitucionalización de los senadores de elección directa en su origen parecía tener carácter transitorio dentro del texto constitucional, de un modo similar a lo que sucede con muchas de las disposiciones del Título VIII de la Constitución, ya que su utilización como circunscripción se decidió cuando se sabía con certeza que sería superada como unidad fundamental de la organización del Estado, pero se estructuró sin establecer un procedimiento automático de sustitución de estos senadores de elección directa por otros de designación o elección autonómica. La representación territorial a la que alude el art. 69.1 CE hace fundamentalmente referencia a la provincia y al hecho insular o a los territorios no integrados en la península. Aunque el Tribunal Constitucional consideró que el Senado es «Cámara de representación territorial» (art. 69.1 CE), integrada por miembros directamente elegidos por el cuerpo electoral de las provincias y por miembros designados por las Comunidades Autónomas (STC 40/1981 FJ 1d), lo cierto es que no existe un cuerpo electoral de las provincias, ni en sentido estricto una representación de la provincia, sino una simple utilización de la provincia como circunscripción electoral tal como aluden expresamente los art. 69.2, 3 y 4 CE. La selección a favor de una circunscripción electoral en el Senado basada en las provincias, dejando al margen la heterogeneidad demográfica entre ellas y el diferente número de provincias existentes en cada Comunidad Autónoma (hay comunidades uniprovinciales y otras que tienen ocho provincias), provoca un efecto distorsionador más grave que el que afecta al Congreso de los Diputados como consecuencia de establecer un número fijo de senadores e igual para todas las circunscripciones sin tomar en consideración el número de habitantes existentes en cada provincia. 
En cualquier caso, a diferencia de lo que sucede en el sistema electoral del Congreso de los Diputados en el que es posible modificar los efectos sin reformar la Constitución, en el caso del sistema electoral del Senado con unas reglas estrictas y concretas fijadas en el texto constitucional se hace imprescindible una reforma. En este contexto se debe valorar el anteproyecto de reforma constitucional planteado en el informe-dictamen del Consejo de Estado solicitado en la anterior legislatura por el Gobierno. En mi opinión, parece correcto plantear una reforma de mínimos que implique un giro autonómico en la composición del Senado y su orientación como cámara de representación territorial basada en la estructuración actual de los territorios en Comunidades Autónomas. En relación con la propuesta, estoy de acuerdo con disminuir el número de senadores provinciales y aumentar el número de senadores autonómicos, ya que sin despreciar las distintas representaciones territoriales, se puede cualitativamente realizar una gran modificación orientada a una mayor federalización del órgano. El informe del Consejo de Estado plantea elegir un único senador provincial (en lugar de los 4 actuales) más 6 senadores fijos por Comunidad Autónoma y otro más por cada millón de habitantes o fracción. En su conjunto el número de senadores desde una perspectiva global será similar al actual y no hay unos planteamientos excesivamente diferenciados a los actuales, al margen evidentemente de la reorientación cualitativa de la representación territorial del Senado.

En relación al Congreso de los Diputados, si un sistema electoral tiene en cuenta la población de cada circunscripción como criterio de proporcionalidad, el número de escaños debe variar proporcionalmente, pero en las distintas circunscripciones con frecuencia esta proporcionalidad no es exacta a causa precisamente del número de escaños, que aparece limitado y preestablecido en la Constitución, del órgano cuya composición se decide en las elecciones, así como de las acusadas desigualdades y disparidades demográficas de población entre las distintas circunscripciones. En general, en nuestro sistema la estabilidad inicial que podía haber proporcionado el establecimiento de la provincia como circunscripción se ha visto distorsionado por la distribución de un escaso número de escaños y por el alto número de circunscripciones. De este modo, no es extraño que se haya planteado no sin razón que una posible solución a los problemas de constitucionalizar como circunscripción electoral a la provincia podía haber sido la utilización de las Comunidades Autónomas como marco territorial constitucional, pero presentaba el grave inconveniente de que aún no estaba configurado el mapa autonómico. La lógica de las Comunidades Autónomas como circunscripción no formaba parte de la conciencia política cuando se aprueba la Constitución, ya que aún no se había adoptado la decisión de generalizar el proceso autonómico a todo el territorio estatal, ni por supuesto era clara, ni pacífica la delimitación territorial de algunas de las posteriormente formadas Comunidades Autónomas. En cualquier caso, en la actualidad estos problemas se han superado, mientras que la provincia ha perdido protagonismo en la vida política, los límites geográficos y el protagonismo político ha recaído progresivamente en las Comunidades Autónomas, que podrían actuar como circunscripción dentro de un proceso de actualización de las instituciones, pero la sustitución de la provincia por la Comunidad Autónoma como circunscripción en el sistema electoral del Congreso de los Diputados tiene el inconveniente de que requiere una reforma constitucional. Sin embargo, la adopción de fórmulas mixtas, que combine la circunscripción provincial con otros tipos 
de circunscripciones, desde un punto de vista territorial, ya sean menores (de alcance comarcal) o mayores (de ámbito autonómico o estatal), no requiere en la práctica de reforma constitucional para su adopción, siempre que se mantenga la circunscripción provincial como la principal.

En este sentido, las dos vías son factibles (reformar la Constitución o la LOREG), pero soy partidario de orientar las reformas hacia la LOREG en el caso de que se deseara a un cambio para mejorar la proporcionalidad, pero al mismo tiempo combinado con una suficiente garantía de la estabilidad gubernamental sin excesiva fragmentación parlamentaria. El único margen posible de conformidad con las reglas constitucionales residiría en añadir los 50 diputados no utilizados según la norma constitucional (un máximo de 400 diputados) en torno a la posibilidad contemplada por la doctrina de añadir una circunscripción estatal de 50 diputados que se repartirían a partir de los resultados globales a nivel estatal con la fórmula D'Hondt produciendo unos resultados similares a los de las elecciones al Parlamento Europeo. Para evitar susceptibilidades se podría permitir a las candidaturas que se presenten exclusivamente en una Comunidad Autónoma (partidos nacionalistas) unirse entre ellas tal como sucede en las elecciones europeas, pero lo cierto es que los resultados permitirían a los partidos una representación proporcional a su implantación a nivel estatal siempre que se superara la barrera mínima (que podría mantenerse en el 3\% o elevarse al 5\%), pero al mismo tiempo cohesionaría a los partidos nacionalistas en la formación de la voluntad política estatal y facilitaría la obtención de unos mejores resultados a los partidos mayoritarios. Para imaginarse la relevancia de este cambio bastaría sumar los resultados obtenidos en las últimas elecciones al Congreso de los Diputados con el global a nivel estatal para comprobar las virtudes de añadir esta nueva circunscripción estatal tanto a nivel de mejorar la proporcionalidad en los resultados como en facilitar y permitir una mayor estabilidad en la formación del Gobierno.

De todos modos, la opción por un determinado régimen electoral se debe valorar en términos jurídico-políticos a través de tres factores, es decir, la articulación de la representación política, los mecanismos utilizados para favorecer la concentración del voto de los electores y para determinar un vencedor electoral y, por último, la articulación de la participación del elector en el proceso electoral y el alcance de su decisión. Un régimen electoral no puede satisfacer de un modo absoluto y al mismo tiempo una representación justa y equilibrada de todos los intereses y fuerzas sociales y políticas presentes en una sociedad, una relación perfecta entre votos y escaños, una efectividad del funcionamiento del sistema político con una reducción del número de opciones políticas que garantice una estable mayoría de gobierno y una responsabilidad política basada exclusivamente en la relación de elector y representante sin intermediarios que imposibiliten o dificulten la decisión del elector y su operatividad durante el periodo decisorio. En cualquier caso, la imposibilidad de que un sistema pueda garantizar de modo absoluto y a la vez estos factores, no es obstáculo para examinar el tipo de respuesta otorgada a dichos factores y el grado de satisfacción que se alcanza desde un punto de vista normativo. Ahora bien, desde cada uno de los tres factores no se puede esperar una respuesta constitucional que sea maximalista de su contenido y que pueda ser operativa sin detrimento del resto de los factores. Las respuestas constitucionales o legislativas maximalistas no son satisfactorias, ya que los tres factores actúan de forma comunicada de modo que el aumento de la re- 
presentatividad justa y equilibrada implica la pérdida de capacidad del resto de los factores y viceversa. Un régimen electoral se debe examinar a partir del grado de equilibrio obtenido entre los diversos factores, de forma que una interpretación constitucional de los principios y normas que incidan en la materia electoral debe tener en cuenta la determinación de dicho grado de equilibrio a partir de criterios sistemáticos y de ponderación de los distintos factores.

En cambio, no soy partidario sin una clara reflexión sobre las consecuencias de alguna de las propuestas del denominado movimiento de los indignados. En este sentido, se debe tener en cuenta que la introducción del voto preferencial por el tipo de campaña electoral actual, deja poco margen y sin peso específico a los candidatos, ya que la campaña se centra en los líderes y en los partidos políticos. La práctica demuestra que un sistema de listas abiertas puede inducir a que exista competencia entre candidatos del mismo partido, campañas electorales al margen del partido y la existencia de facciones en el seno de un partido que incluso pueden estar apoyados por grupos externos al propio partido. Entre las ventajas de la introducción del voto preferencial se situaría la mayor capacidad de decisión de los ciudadanos, una expansión de las elites parlamentarias, una mayor relación entre los representantes y los electores, una disminución del poder de los aparatos burocráticos de los partidos. Pero en nuestro sistema de partidos existen numerosos elementos que dificultarían la introducción de un voto preferencial como la débil implantación de los partidos, el bajo nivel de afiliación y de identificación partidista entre el electorado, el mínimo papel de los candidatos provinciales en la decisión electoral, el bajo nivel de conocimiento de los candidatos provinciales (y un correlativo bajo esfuerzo para darse a conocer a lo largo de la legislatura), la personalización de la política en base a la identificación de los partidos con los líderes, una propensión al voto útil por parte del electorado y un proceso de comunicación política basado en el líder y en el aparato central de los partidos (aunque con posibilidades de modificación a partir de la incidencia que puedan tener las televisiones autonómicas y locales). Incluso se han desarrollados críticas más o menos generalizadas al sistema de voto preferencial, ya que tiende a fomentar el clientelismo y el neocaciquismo, no resultando, por otra parte, un mecanismo eficaz frente a la maquinaria directiva de los partidos (incluso se podría afirmar que las refuerza), ni consigue articular una alternativa a la disciplina parlamentaria. En este contexto, se puede insistir en la idea de la existencia de numerosos argumentos a favor y en contra de las listas cerradas y bloqueadas, de las listas abiertas o del voto preferencial, pero al mismo tiempo se debe resaltar en unión al voto electrónico que la gestión de un sistema u otro es bien distinta, debiéndose recurrir necesariamente a instrumentos de nuevas tecnologías en el caso de que se desee optar por algún sistema distinto del actual.

En relación a las funciones básicas de ambos órganos legislativos no creo que exista excesiva problemática por más que sean criticables medidas de la práctica diaria, aunque al no incidir en esas funciones básicas no requieren de reforma constitucional para su corrección o modificación. No obstante, el mantenimiento de un Senado como el actual lo convierte en inútil, por lo que si no tiene un verdadero carácter territorial lo mejor sería suprimirlo, ya que sus funciones en materia de procedimiento legislativo son repetitivas, redundantes e innecesarias, lo mismo que sus funciones de control. 


\section{ALBERTO LÓPEZ BASAGUREN}

En lo que se refiere a la composición del Congreso de los Diputados, la regulación contenida en el art. 68 es tan abierta que no creo que requiera de ninguna reforma; cuando menos, de ninguna reforma que sea factible y que sea razonable plantearse en nuestra situación. Ciertamente, podemos ponernos a hacer ejercicios de imaginación y tratar de importar otros modelos; pero se trataría de puros ejercicios de voluntarismo o de laboratorio, que no serían fáciles de encajar en nuestra realidad.

Los elementos fundamentales que establece el art. 68 de la Constitución que tienen relevancia a estos efectos (entre 300 y 400 miembros, circunscripción provincial, asignación de representación mínima a cada una y distribución proporcional) me parecen difícilmente modificables.

El mayor problema radica, sin duda, en la combinación entre la determinación de que la circunscripción electoral es la provincia y la asignación de una representación mínima a cada una de ellas (más uno a cada una de las ciudades de Ceuta y Melilla). Teniendo en cuenta la distribución de la población por provincias y la existencia de algunas con muy escasa población, la representación puede quedar distorsionada. Pero creo que se trata de dos elementos (provincia como circunscripción electoral y asignación de una representación mínima) que son difícilmente modificables, teniendo en cuenta la realidad española. Quizás hubiese sido deseable que la Constitución no incluyese esos elementos, dejando su determinación a la ley electoral; pero una vez presentes en el texto constitucional, creo que su supresión sería muy conflictiva. Creo, por tanto, que la regulación constitucional de la composición y elección del Congreso no es deseable.

El problema de distorsión de la representación — por exceso en el caso de los partidos grandes y por defecto en el de los partidos pequeños con implantación general en toda España, especialmente llamativo en la comparación con partidos con un similar porcentaje total de votos concentrados regionalmente- debe tratar de paliarse, en mi opinión, en la Ley electoral, dentro de los márgenes del actual art. 68 de la Constitución.

En este sentido, hay dos elementos sobre los que se puede intervenir en la Ley electoral: el número de diputados y el propio sistema electoral. Una opción es, ciertamente, ampliar el número de miembros del Congreso, hacia el máximo de la horquilla establecida en la Constitución, lo que permitiría ajustar mejor la proporcionalidad. Pero esa opción plantea otro tipo de problemas de imagen (incremento de la «clase política») en unos momentos de gravísima crisis económica y de descrédito de los políticos. Una medida de este tipo sería, quizá, más fácil de plantear en el contexto de la reforma del Senado, si se produjese una reducción significativa del número de Senadores. En relación al sistema electoral, se deberían analizar las diferentes opciones de sistemas proporcionales y ver si aportan mejoras significativas. Pero creo que no sería fácil modificar una tradición ya tan consolidada (sistema D’Hondt). Y creo, en todo caso, que la búsqueda de la máxima proporcionalidad no es un principio al que haya que subordinar todo el diseño del sistema electoral, en el que hay que tener en cuenta otros objetivos (representación de todas las zonas del territorio y facilitar la estabilidad de gobierno).

Por el contrario, creo que es necesaria una profunda reforma del Senado. Especialmente, su composición y, quizás, también, en parte, sus funciones. En este ámbito, creo que el Informe del Consejo de Estado puede ser de gran utilidad. El Senado debe re- 
flejar la estructura autonómica del Estado; sus miembros, por tanto, deben elegirse fundamentalmente - en las Comunidades Autónomas, representando a éstas. Y creo que la mejor opción es su designación por la Cámara parlamentaria, respetando la existencia de minorías.

Debe intentarse un Senado con un número reducido de miembros, en el que se tengan en cuenta las diferencias de población de unas y otras Comunidades Autónomas, pero estableciendo una horquilla estrecha entre las de mayor y las de menor representación. La idea del Consejo de Estado de añadir Senadores de elección provincial puede ser muy positiva (1 Senador por provincia cumpliría el objetivo), en la medida en que hay Comunidades Autónomas con un elevado número de provincias, con fuerte personalidad. Pero eso exigiría una reducción importante del número básico de Senadores por cada Comunidad Autónoma (considerablemente inferior a los seis que propone el Consejo de Estado), estableciendo el número de Senadores de cada Comunidad Autónoma a designar por la Asamblea Legislativa en una escala que tenga en cuenta las diferencias de población, pero en una horquilla estrecha y partiendo de un número bajo (por ejemplo, 3). No veo la necesidad de que una Comunidad Autónoma de una sola provincia y menos de un millón de habitantes tenga más de tres o cuatro Senadores. Ni que la Comunidad más poblada y con más provincias tenga más de, por poner un ejemplo, 14 Senadores.

En mi opinión, la reforma del Senado es una de las cuestiones en las que tenemos que hacer un mayor esfuerzo por cambiar los presupuestos de los que partimos. Me parece preferible un Senado más pequeño que, en su caso, permitiese configurar un Congreso más numeroso — dentro de los límites del art. 68-, que corrigiese, en parte, las distorsiones más llamativas de representación en el Congreso de los pequeños partidos de implantación general en España.

En relación con las funciones del Senado, creo que debe mantenerse un bicameralismo desequilibrado, que permite al Congreso superar el veto o las enmiendas del Senado a través de una nueva votación que, en caso de veto, exija mayoría cualificada - 0 diferentes mayorías según el carácter cualificado de la mayoría de rechazo obtenida en el Senado, al modo de lo previsto en el art. 77.4 de la Constitución alemana-. Personalmente, soy partidario de introducir, aún de forma muy limitada — no con la amplitud de la Constitución alemana-, la exigencia de la necesaria aprobación por parte del Senado de algunas leyes esenciales en el desarrollo del sistema autonómico. Pero creo que puede tratarse de un salto demasiado grande respecto a nuestra tradición, por lo que habría que tratar, primero, de reformar el Senado de una forma razonable y, a la vista de su funcionamiento y de la evolución del sistema autonómico, analizar la conveniencia de plantear reformas que avancen en esa dirección.

\section{ANTONIO LÓPEZ PINA}

Sin ambages, decididamente. Habiendo forzado al resto de Grupos parlamentarios una Ley electoral positivamente discriminatoria, nuestras minorías territoriales vasca y catalana, que nunca en la Historia española han dispuesto de tantas garantías de preservación de su identidad cultural, han desnaturalizado nuestro régimen parlamentario. El lugar político de las minorías territoriales no debe ser otro que la Cámara territorial. 
6. ¿Qué nos quiere decir sobre la pertinencia y posibilidad de reformar el Titulo VIII —organización local y autonómica- y sobre las orientaciones que debieran presidir, en su caso, la reforma?

\section{ELOY GARCÍA LÓPEZ}

La organización territorial del Estado ha sido el gran tema de debate en torno al que han gravitado los problemas de la reforma Constitucional desde 1978. La última sentencia del TC a propósito del Estatuto de Cataluña, parece haber introducido una cierta racionalidad y en alguna medida ha supuesto un punto final en ciertas cuestiones como los límites a la transferencia de competencias. Y me parece que es importante porque en buena medida se trata de un debate que sin ser falso, ha servido para encubrir otros problemas más importantes, como los de la democracia, la responsabilidad de los gobernantes y la prestación efectiva de unos servicios que son tan importantes como las libertades fundamentales.

Justamente el planteamiento de estos últimos problemas desde el ámbito local, es algo que se echa en falta en la Constitución. Nuestra realidad es urbana, pero la Ciudad no está en la Constitución. Y eso es algo que ha generado problemas muy graves porque el siglo XXI se está desvelando como el siglo de la Ciudad entendida en el sentido de Lewis Munford, un autor imprescindible para nuestra época. La Ciudad en el momento actual aparece como el punto de engarce de dos dimensiones fundamentales del hombre contemporáneo a las que he tenido oportunidad de referirme antes: la democracia y los servicios prestacionales. La Ciudad en un mundo de enormes dimensiones espaciales, aparece como el único supuesto capaz de atar, de enraizar al hombre en una realidad tangible. Es esa realidad tangible la que le puede permitir participar activamente en las decisiones de gobierno que le afectan y que son tomadas en su nombre. La ciudadanía debe ser una cualidad activa que se ejerce antes que en ningún otro lugar en la Ciudad, allí dónde nos afectan de manera más inmedita las decisiones tomadas desde el poder. También la Ciudad es el ente que nos presta los servicios más imprescindibles, los que aseguran nuestro acceso al mínimo vital imprescindible, el urbanismo, la movilidad, el agua, la eliminación de los residuos.

En estos días empezamos a apreciar en España, tal vez más que nunca, lo que ha significado ir contra con unas administraciones municipales que han desconocido su función real. Regenerar la Ciudad desde el binomio democracia-servicios es una tarea de una dimensión tal que justificaría muy bien una modificación de la Constitución. Y no se trata sólo de reparar el olvido de 1978, sino de abrir nuestra Ley Fundamental a las nuevas inquietudes del siglo XXI.

\section{JUAN CARLOS GAVARA DE CARA}

Si existe algún tipo de consenso doctrinal es la necesidad de modificar el Título VIII de la Constitución, ya que su configuración tenía carácter procedimental y reivindicativo, planteándose un acuerdo generalizado en que se debe ofrecer estabilidad y 
sustancialidad material a la distribución de competencias. El desacuerdo se sitúa en su concreción.

En todo caso en mi opinión se deberían fijar exclusivamente las competencias del Estado a través de una única lista en la que se incluyeran sus competencias exclusivas, compartidas y concurrentes, es decir, suprimir la doble lista, tanto la explícita de carácter procedimental que ha perdido su sentido originario por inútil como la implícita que implica que las competencias autonómicas se fijen estatutariamente. Las competencias deben responder a un único criterio de reserva constitucional de las competencias estatales y competencia residual para las Comunidades Autónomas. En definitiva, para lo que no es competente el Estado deben ser competentes las Comunidades Autónomas de forma obligatoria, si no ejercen dichas competencias deben formar parte de su responsabilidad política exigible en última instancia electoralmente, eliminando parte de los conflictos de competencia. La lista única elimina el problema de la constante apertura del sistema e implicaría la supresión del art. 150.2 CE, ya que las competencias estatales deben considerarse indelegables, salvo reforma constitucional. En este sentido, la distribución de competencias en ningún caso puede ser afectada por el legislador, sea ordinario, orgánico o estatutario, ya que se trata de una materia constitucional irrenunciable, que no debe formar parte de la discusión política, sino directamente del texto constitucional en todas sus versiones, aunque se deba reformar la Constitución frecuentemente.

La articulación de una lista única de competencias estatales y cláusula residual a favor de las Comunidades Autónomas resolvería en gran medida la problemática de la reforma de los Estatutos de Autonomía que no tendrían el rol de normas de articulación de competencias, sino de estructuración orgánica e institucional y de garantía de derechos, sobre todo de carácter social, de los ciudadanos autonómicos.

La mejora del sistema requeriría que en competencias concurrentes con competencias normativas del Estado, es decir, las bases normativas de las distintas competencias deben identificarse formal y materialmente, es decir, reconvertir a la ley marco del art. 150.1 CE en un instrumento pensado para adoptar regulaciones estatales de carácter básico sobre competencias concurrentes, dejando de tener un rol marginal inoperante. La falta de esa identificación formal-material de las bases normativas ha hecho perder solemnidad a su importancia dentro de un modelo de federalismo cooperativo imperfecto en el que nos hemos estructurado, implicando que otros órganos constitucionales como el Tribunal Constitucional determinen su alcance, cuando claramente se trata de una decisión política.

Desde otra perspectiva, aunque no ha sido utilizada en la práctica la Ley de Armonización prevista en el art. 150.3 CE, se debe garantizar que en un futuro su utilización solo debe venir enmarcada y justificada para la protección de un ejercicio igualitario de derechos fundamentales en las distintas Comunidades Autónomas que debe ser su único parámetro de referencia para determinar su oportunidad y conveniencia (excluyendo algunas especificidades como la lengua propia o las derivadas del territorio insular). De este modo se debe convertir en un instrumento normativo llamado a ejercer un rol trasversal importante en un nuevo contexto.

Esta restricción de los instrumentos normativos de armonización debe ir acompañado de un uso, incluso constitucionalizado de la competencia de la alta inspección del Estado en todas las competencias concurrentes, ya que numerosas desigualdades o di- 
rectamente incumplimientos han surgido en la ejecución de competencias por parte de las CCAA. A pesar de tener la competencia el Estado ha realizado un desuso de la misma que se requiere recuperar sobre todo en la situación de crisis económica globalizada frecuentemente provocada en parte por la ejecución de competencias autonómicas. El Estado debe volver a desarrollar y ejercer de inspección, recurriendo a administración especializada en ámbitos competenciales trasversales.

Evidentemente esta reforma debe ir acompañada de una restructuración del Senado para su articulación como una verdadera cámara de representación territorial, que modifique sustancialmente el actual modelo de este órgano. Aunque se podría emprender una reforma de mayor profundidad y calado de este órgano, por lo menos se deben realizar los cambios previstos en el informe del Consejo de Estado para modificar su fisionomía.

En el otro aspecto de la organización territorial no creo que sea necesario insistir en la supresión de las Diputaciones Provinciales, aunque por lo menos deben dejar de tener una relevancia constitucional. En aquellas CCAA en las que se deban mantener por sus peculiaridades debe ser una competencia autonómica, aunque en el fondo cuantas menos organizaciones de carácter institucional existan mejor. Las Comunidades Autónomas deben facilitar la cooperación supramunicipal para la mejor gestión de servicios que puede ser asumida directamente por la Comunidad Autónoma o eventualmente por un organismo independiente o cooperativo, pero no por una institución. En este contexto se debe resaltar que sobran cargos públicos en general y municipales en particular, ya que las administraciones locales permiten reducir con facilidad los cargos políticos (y seguramente es válido para todos los ámbitos territoriales), es decir, debe haber menos concejales, diputados autonómicos y duplicidades de cargos para un funcionamiento más estable.

La reforma del sistema de financiación autonómica, tras las sucesivas reformas de la LOFCA, pasaría por dejar un cierto recorrido para determinar las consecuencias prácticas de la última reforma y la corrección constitucional de algunas deficiencias estructurales en el sentido de suprimir cualquier privilegio entre CCAA que pueda suponer una falta de respeto al principio de solidaridad y de cohesión territorial en una clara tendencia a establecer un sistema de financiación autonómica único y sin singularidades bilaterales. En este sentido, no debe tener cabida en el marco constitucional un sistema de cupo no integrado en los mecanismos de compensación y solidaridad territorial, ni articulación de relaciones bilaterales Estado-CCAA en la negociación de dicha financiación o la existencia de obligaciones de porcentajes de inversión pública en CCAA incompatibles con la articulación de un sistema general. En general las disposiciones del sistema de financiación autonómica establecidas en la Constitución se deben corregir ya que han quedado obsoletas en relación a la articulación actual. En materia de recaudación, o incluso cuando cualquier materia competencial cree un exceso de tirantez en las relaciones, se debe recurrir a la idea de la administración independiente, es decir, al margen del Estado y de las CCAA para intentar solventar problemas. Esa debería ser la situación real de la Agencia Tributaria sin tener que recurrir a fórmulas como el concierto que generarían más desigualdades y conflictos en un futuro.

En general, considero que en nuestro sistema autonómico se debe corregir la vertiente reivindicativa y procedimental para profundizar en la vertiente de responsabilidad del gobierno autonómico y sustancialidad de la articulación de las reglas. Finalmente, 
además creo que se debería reformar o suprimir los preceptos que tienen carácter procedimental vinculados al proceso de creación de las CCAA, los preceptos sobre la elaboración inicial de los Estatutos, así como muchas disposiciones transitorias y adicionales que han perdido su sentido en la actualidad. En definitiva, se propugna profundizar en un sistema de federalismo cooperativo con un grado de asimetría garantizado, justificado y previsto exclusivamente en la Constitución siempre que no incida en excesivas materias (lengua propia o insularidad).

\section{ALBERTO LÓPEZ BASAGUREN}

Creo que la reforma constitucional del sistema autonómico es uno de los retos más importantes en nuestro horizonte. Algunos pueden pensar que perdemos demasiadas energías en cuestiones internas, en lugar de dedicarlas a ser más fuertes económicamente y ante el mundo. Aunque esa apreciación fuese cierta, no podremos encarar ese reto si no resolvemos adecuadamente nuestra configuración como país.

Hemos vivido durante veinticinco años convencidos del éxito del diseño del sistema autonómico. Incluso muchos de sus críticos partían de ese reconocimiento. Pero hace ya casi un decenio que la incapacidad de resolver los problemas del sistema autonómico está provocando una importante deslegitimación del sistema. Lo que hasta hace poco era un problema de impugnación por parte de los nacionalismos vasco y catalán, como consecuencia de pretensiones particulares que iban más allá del sistema constitucional, se ha convertido, en estos momentos en problemas funcionales del sistema autonómico que han hecho incrementarse las filas de quienes consideran que es necesario afrontar la reforma.

El proceso de elaboración de los Estatutos de Cataluña y de Andalucía, fundamentalmente, y la STC 31/2010, sobre el Estatuto de Cataluña, han puesto de relieve que la reforma del sistema autonómico solo se puede abordar de forma idónea a través de la reforma de la Constitución. Por otra parte, el Título VIII de la Constitución ha cumplido ya su función, en la medida en que, en gran parte, es derecho transitorio que ya carece de sentido. Esto es lo que trataba de realizar, aún de forma muy limitada, la propuesta del Gobierno de incorporar a la Constitución los nombres de las Comunidades Autónomas. Pero los problemas de reforma del sistema autonómico que debemos afrontar son de más calado que el propuesto por el Gobierno.

En mi opinión, debemos afrontar los problemas funcionales del sistema autonómico que se han ido poniendo de manifiesto en su desarrollo durante estos más de treinta años y las reclamaciones de profundización de la autonomía por parte, al menos, de algunas Comunidades Autónomas; problemas que, en ocasiones, confluyen. Y creo que esta evolución se debe hacer en la perspectiva de los sistemas federales de nuestro entorno.

Aunque el sistema federal tiene un oscuro pasado en España y ha sido tradicionalmente abominado, especialmente entre los partidos de derecha, los sistemas federales de nuestro entorno han demostrado una contrastada capacidad para garantizar la estabilidad política en condiciones muy satisfactorias. Por otra parte, prestigiosos estudiosos foráneos del federalismo hace tiempo que vienen afirmando que España es ya un sistema federal «en todo salvo en el nombre» (Daniel J. Elazar) o «disfrazado» (Ronald Watts) —aunque algunos estudiosos españoles se resistan a ese reconocimiento, entre ellos, quienes pre- 
tenden monopolizar una comprensión particular del federalismo, tratando de resaltar las deficiencias del sistema español en la negativa a ese reconocimiento-.

La mirada a los sistemas federales nos tiene que servir para plantearnos soluciones idóneas a los problemas del sistema autonómico, en la línea en que lo han hecho otros sistemas federales y también a superar las peculiaridades del sistema español, en la pretensión (histórica) de alejarse del federalismo, que se han demostrado fuente de problemas una vez que cumplieron la función histórica de concretar lo que quedó abierto en el momento constituyente (principio dispositivo, función «constitucional» de los Estatutos).

En esta dirección, creo que hay que afrontar la necesidad de clarificar la delimitación material de las competencias autonómicas para cerrar para siempre la inacabable polémica sobre las transferencias, que tan importante papel ha jugado en la descalificación del sistema autonómico por parte de los partidos nacionalistas — especialmente, los nacionalistas vascos-

Creo que, de la misma forma, hay que afrontar una más nítida separación de los ámbitos de competencias, respectivamente, del Estado y de las Comunidades Autónomas. En este ámbito es indispensable afrontar el tema de la distribución de competencias en torno al eje bases estatales/desarrollo autonómico. Este es el mayor problema de nuestro sistema autonómico. Y habrá que plantearse la idoneidad de que constituya el eje del sistema de distribución de competencias cuando, salvo de forma excepcional en el caso austriaco, ningún sistema federal lo acoge —y la reforma alemana de 2006 tuvo en su rechazo uno de los elementos más importantes-.

Asimismo, hay que lograr un sistema de financiación satisfactorio, estableciendo en la Constitución los principios básicos, de forma que se garantice una distribución de recursos que eluda los problemas más significativos de los sucesivos sistemas que se han ido sucediendo hasta el presente — siempre con la pretensión de definitivos-.

Hay que plantearse, como ya se ha dicho más arriba, la reforma del Senado.

Y creo que será inevitable plantearse el reto de las estrategias soberanistas de los nacionalismos vasco y catalán. A partir de lo que ocurra en Escocia con la pretensión del Gobierno escocés del SNP de celebrar un referéndum y el órdago lanzado por el premier David Cameron, la utilización del ejemplo escocés va a reforzar la presión en este ámbito.

Se trata de una tarea ingente, que no se puede tratar de abordar ni de forma precipitada ni de una vez. Por eso es importante no dejar que los problemas se sigan acumulando, que la crisis del sistema se agudice y que, finalmente, las reformas que haya que afrontar sean de una trascendencia difícil de gestionar políticamente. La reforma constitucional del sistema autonómico tiene que plantearse como un trabajo continuado, en distintas etapas, con una gran labor política acompañada de una no menor labor técnica. Es decir, con debate y maduración. Como lo hacen los países que mejor lo hacen. Es decir, de forma radicalmente opuesta a como, tras el éxito de la elaboración de la Constitución y de los Estatutos de «primera generación», venimos acostumbrándonos a hacer las cosas.

\section{ANTONIO LÓPEZ PINA}

La diferenciación entre soberanía estatal y autonomía de las Comunidades Autonomas debe ser tan rotunda como nítida, con rigor jurídico-conceptual. La autonomía 
municipal y su base material, en términos de dotación financiera, me parecen fundamentales.

La distribución de competencias debe ser tanto como posible depurada de ambivalencias propiciadoras de conflictos institucionales, en términos de a) competencias exclusivas del Estado, b) competencias exclusivas de las Comunidades Autónomas y c) competencias compartidas.

Todo ello deberá servir de armazón institucional, formal y sistemáticamente cerrado — no, abierto y a disposición, como ha sido el caso de la Constitución de 1978 desde su aprobación-, al Estado federal.

7. A la luz de la reciente reforma del artículo 135 del texto constitucional, ¿podría realizar una valoración sobre su pertinencia, sobre el contenido sustantivo y sobre la literalidad de la misma?

\section{ELOY GARCÍA LÓPEZ}

Para empezar y en lo que se refiere a las formas no veo en el procedimiento seguido para modificar el artículo 135 de la CE, nada extraordinariamente inusual, lo que no quiere decir que su tramitación no haya dejado de incurrir en vicios sobre todo en lo que hace a la iniciativa o que el resultado sea bueno o incluso deseable. Había que hacer con urgencia un gesto. Se hizo. Se consiguió un efecto temporal, en principio beneficioso, aunque fuera a costa de recordarnos que la norma constitucional que introducía la reforma, en la medida en que se conformaba como una clausula abierta a desarrollar por ley orgánica, no aspiraba a crear un orden, a dar estabilidad, a dominar la Política por mucho que aparentara lo contrario. Y esta manera de entender las cosas característica de la posmodernidad, se encuentra en flagrante contradicción con la idea de derecho imperante en el paradigma juridicista construido en el siglo XVIII al que me referí en la respuesta a la $1^{a}$ pregunta.

En relación con esto conviene insistir en que, ni el propósito final, ni el tenor literal del nuevo precepto 135, sirven para otra cosa que para crear un efecto, para generar una impresión y no para fundamentar una decisión de futuro o para sustentar una serie de medidas por venir; ni siquiera entra en la categoría de aquellas leyes-medida a las que se refiriera Schmitt. Aunque la nueva redacción del artículo de la Constitución parece querer imponer una conducta para el futuro, lo cierto es que ese fin resulta secundario respecto del verdadero propósito que busca la norma: frenar la especulación financiera.

Los destinatarios de la reforma del artículo 135 son pues, unos mercados hambrientos de resultados económico-financieros, y también, una sociedad nacional que empezaba a preguntarse si efectivamente se estaba haciendo algo, tomando medidas contra lo que en los medios se presentaba como la crisis financiera más pavorosa después de 1929. Pero no había ningún interés en obtener un resultado definitivo (y de ahí la redacción de la norma, abierta, vaga, inconcreta y necesitada de una ley posterior para dotarse de contenido efectivo). Lo importante era — repito - producir un efecto, no imponer una conducta pro futuro. $\mathrm{Y}$ eso es algo que sucede cuando no hay ideas, cuando por definición las acciones políticas carecen de sentido de trascendencia y solo sirven en una 
breve proyección temporal, en un instante y no para forjar un tiempo histórico. Y esa situación se produce cuando la norma en sí paradójicamente pretende imponer el principio de sostenibilidad financiera para el futuro. Una sostenibilidad que de cambiarse de criterio, y si en alguna cosa hoy en día no hay criterio fijo es en economía, muy bien pudiera llegar a ser reemplazada por una política inflacionaria y de déficit financiero controlado, como de hecho actualmente están recomendando ciertas opiniones económicas, bien es cierto que minoritarias.

Es cierto que el gobierno actual de Mariano Rajoy, ha anunciado un desarrollo legislativo al respecto que otorgará a la obligación de equilibrio presupuestario, un contenido imperativo, vinculante, propio de lo que tradicionalmente llamábamos una norma. Pero sin esa ley que ahora prepara el gobierno, estaríamos ante la incorporación de un nuevo apartado al artículo 135 que no sabría si calificar de programático, de vacío, o de compromiso apócrifo e inútil. Es así como la polémica alemana de los años de Weimar, y los trabajos de los años sesenta y setenta de Calamandrei, Crisafuli o Lechner nada podrían aportarnos respecto de su definición y eso es muy indicativo de lo que está pasando. No podemos enjuiciar ni la reforma del artículo 135, ni el derecho por ella creado, desde el parámetro de lo que debiera ser una norma constitucional llamada a crear un orden, desde las reglas que nos trasmitieron los clásicos, sino desde la lógica de lo virtual y de lo mediático. Y hacer de la Constitución un efecto virtual, es muy peligroso, es lo mismo que degradarla en su sustancia última, en aquella voluntad de Constitución de la que hablara Hesse.

Pero más inquietante que todo esto con serlo mucho, lo es todavía la atmosfera que se ha generado a raíz de la iniciativa que ha concluido en la última reforma en relación con las acciones del poder. Decía Franklin D. Roosevelt, que el gobernante democrático debe ejercer de pedagogo social. Debe procurar educar con sus actos a la sociedad en que gobierna. Gobernar es ante todo dar ejemplo de conducta pública, y la forma en que se ha ejercido la iniciativa en esta última reforma parece demostrar que el gobernante no sentía la necesidad de tomar en cuenta a la sociedad, o mejor dicho a la comunidad nacional que lo ha elegido. Un Presidente del gobierno que toma una decisión y que para llevarla a cabo considera que no requiere de otro acuerdo que el del líder del partido de la oposición, que a su vez se encuentra políticamente cogido por su propia palabra, da la impresión de un gobierno de pocos, de unos pocos que, además, no se consideran sometidos a una legalidad que pueden hacer y deshacer a su antojo. Las viejas máximas de Bracton y Fortescue tiemblan, porque los partidos, el Parlamento, la opinión, la doctrina, los electores, todos los sujetos constitucionales que comparten el poder político y la iniciativa de la reforma constitucional, no han desempeñado en esta ocasión ningún papel sustancial. Y la pregunta que a continuación se impone es clara, ¿qué papel juegan en realidad todos estos sujetos en la toma de la decisión política?

\section{JUAN CARLOS GAVARA DE CARA}

El nuevo art. 135 CE establece la inclusión del principio de estabilidad presupuestaria en la Constitución que vinculará a todas las Administraciones Públicas en su actuación. Este principio se conoce como la regla de oro o la introducción de un límite 
constitucional del déficit en el texto constitucional, cuya objetivo es limitar la posibilidad de un gobierno de gastar más que lo que recaude y así limitar el crecimiento de la deuda pública para garantizar la sostenibilidad de las finanzas publicas a largo plazo, es decir, regular la estabilidad presupuestaria. Quizás éste sea el contenido sustancial más novedoso, si por novedoso entendemos que se trata de su inclusión en la Constitución y elevar su rango, ya que del ordenamiento jurídico formaba parte a nivel legislativo (Ley 18/2001, General de Estabilidad Presupuestaria en la versión por el texto refundido R.D. Legislativo 2/2007). El objetivo de esta disposición es claramente limitar de forma negativa el endeudamiento de las Administraciones Públicas, ya que se presupone que no cumplían con su contenido en el sentido de que se estaban endeudando por encima de su capacidad. Debe destacarse que el principio es de estabilidad presupuestaria y no de equilibrio presupuestario (salvo para las Entidades Locales), que claramente sería incompatible con un Estado social y democrático de Derecho. La estabilidad presupuestaria es necesaria para la sostenibilidad económica y social del Estado en el tiempo, evitando hacer recaer en generaciones futuras decisiones económicas del presente, racionalizando los recursos y controlando el endeudamiento.

El art. 135.2 CE establece que el Estado y las CCAA no podrán recurrir en un déficit estructural que supere los márgenes establecidos por la Unión Europea para sus Estados miembros. Aquí surge un primer error de redacción, ya que dichos márgenes se regulan actualmente en el Derecho originario que sigue siendo fruto de la cooperación intergubernamental, es decir, son los propios Estados los que los fijan en los diferentes Tratados, actualmente en los protocolos del Tratado de Lisboa. La redacción del precepto sugiere que serán las autoridades de la Unión Europea las que fijen dichos márgenes para los Estados miembros, cuando han sido los propios Estados los que los han fijado y los que seguramente fijarán dichos márgenes en un futuro ya sea mediante Tratados de Derecho originario o la cooperación reforzada en el caso de que se avance en la unión fiscal. En todo caso por más que sea admisible que la Unión Europea intente establecer unos criterios uniformes para los Estados miembros que eliminen las fluctuaciones económicas diferenciadas, no lo es tanto que se mencione en la Constitución que una autoridad externa a su forma de gobierno sea la competente exclusivamente para dictar el endeudamiento del Estado, ya que sus competencias no resultan de nuestra Constitución, ni tan siquiera en forma de renuncia, sino a través de los correspondientes tratados internacionales que constituyen el marco supranacional en el que se integra España.

En un segundo inciso el art. 135.2 CE establece que la Ley Orgánica fijará el déficit estructural máximo permitido en relación con el PIB para el Estado y las CCAA. En todo caso, este precepto por exclusión obliga a que las Entidades Locales presenten equilibrio presupuestario, lo que excluye la previsión deficitaria, pero no la posibilidad de endeudamiento o de contraer crédito, ya que en el párrafo siguiente no se menciona de forma expresa a la Administración local como excluida dicha posibilidad en su presupuesto, aunque evidentemente se puede suprimir o eliminar dicha posibilidad mediante ley.

Finalmente, se debe destacar que este precepto incluye la que debía ser la decisión material más importante de esta reforma, la fijación de la cantidad máxima del volumen de déficit estructural, pero que se reenvía a una decisión legislativa, es decir, se plantea su existencia a nivel constitucional, pero no la concreción de su contenido que se reenvía a una decisión legislativa. Este es el modelo que se sigue en Estados Unidos, ya que el Con- 
greso es el competente para fijar un límite máximo de deuda, pero se debe destacar que desde 1944 el techo ha sido revisado 103 veces, lo que en términos de largo plazo implica reconocer su carácter coyuntural. No obstante, desde el punto de vista del funcionamiento de la economía pública parece que sea la decisión más lógica, aunque el objetivo de fortalecer la confianza en la estabilidad presupuestaria no sale reforzado sin cuantificar el déficit máximo.

El art. 135.3 CE recupera el texto del antiguo art. 135 CE introduciendo algunos cambios como, en el inciso primero, la extensión de la necesidad de una autorización legislativa para emitir deuda pública o contraer crédito no solo al Gobierno tal como reflejaba la antigua redacción, sino al Estado y a las Comunidades Autónomas (criterio sustentado en la STC 134/2011). El cambio es importante ya que se constitucionaliza la necesidad de una autorización, en este caso, legislativa para dichas operaciones, que afectará sobre todo a las Comunidades Autónomas. La LOFCA establece en el art. 14 la necesidad de una autorización del Estado, por lo que de una forma abierta se entiende que debe realizarse por mandato constitucional a través de una ley formal de las Cortes Generales.

El art. 135.3 CE en el inciso segundo también introduce un pequeño cambio como la extensión de la obligación de hacer constar los créditos para satisfacer la deuda pública y sus intereses en los gastos de los presupuestos de todas las Administraciones y no solo la del Estado (tal como se mencionaba con anterioridad) y un cambio más relevante que es que el pago de dichos créditos gozará de una prioridad absoluta. Esta norma, cuyos efectos no están especificados, tiene como objetivo fortalecer la confianza en la estabilidad económica de España, en coherencia con el objetivo de la reforma.

$\mathrm{El}$ art. 135.3 CE en el último inciso introduce una nueva regla en el sentido de que el volumen de deuda pública en relación al PIB de todas las Administraciones Públicas no podrá superar el valor de referencia establecido en el Tratado de Funcionamiento de la Unión Europea. Esta última mención incurre en dos errores, ya que dicho valor de referencia se regula en uno de los protocolos adjuntos y por otra parte se hace mención a un tratado concreto. Un mínimo de conocimiento del Derecho originario de la Unión Europea permite conocer que el nombre de dichos tratados ha ido variando desde su origen y que coyunturalmente dicho nombre es en la actualidad el que menciona el precepto constitucional, pero que puede variar en un futuro con una relativa facilidad, lo que puede implicar la necesidad de recurrir a un criterio interpretativo contrario al tenor literal del precepto.

El art. 135.4 CE establece que los límites de déficit estructural y de volumen de deuda pública previamente fijados solo podrán superarse en situaciones extraordinarias o de emergencia que escapen del control del Estado (incluidas expresamente catástrofes naturales o recesión económica) y perjudiquen considerablemente la situación financiera o la sostenibilidad económica o social del Estado. Estas situaciones que pueden dar a una situación de superación de los límites será apreciada por mayoría absoluta del Congreso de los Diputados. En este precepto, se debe destacar que se trata de una decisión, que no es una ley de Cortes, sino que responde al modelo de autorización, que puede implicar la suspensión singular de la aplicación de leyes, pero sin suponer su derogación o sustitución. Se trata de unos supuestos de Derecho excepcional, que aunque previstos materialmente en la Constitución, son insuficientemente regulados, con imprecisiones ma- 
teriales y procedimentales, ya que no se establece su carácter temporal o la necesidad de prorrogar mediante nueva decisión su vigencia, o un procedimiento de adopción, por lo que se hace imprescindible un desarrollo normativo o criterios interpretativos. En todo caso dicho desarrollo está previsto en el siguiente párrafo del artículo, pero que no cuenta dicha regulación con ningún límite formal, procedimental o material en el texto constitucional, ya que incluso la regulación de los supuestos excepcionales de superación de los límites se encuentra abierta al desarrollo normativo de los mismos.

El art. 135.5 CE establece que una ley orgánica desarrollará los principios, la participación, los procedimientos y los órganos de coordinación institucional entre Administraciones Públicas en materia de política fiscal y financiera. Dicha Ley Orgánica tiene unos contenidos descritos que actúan como criterios positivos y necesarios de delimitación, de forma que no pueden ser omitidos en la futura ley. Entre dichos contenidos destacan la distribución de los límites de déficit y de deuda pública entre las diferentes Administraciones Públicas (aunque se entienden que las Entidades Locales no participan de dicha distribución por incompatibilidad con el art. 135.2 CE, aunque se deberá concretar en relación con la posibilidad de contraer crédito), la delimitación de los supuestos excepcionales de superación de los límites de déficit estructural y de deuda pública, así como la forma y el plazo de corrección de las desviaciones que puedan producirse en los casos de superación por los supuestos excepcionales. En segundo lugar, se debe incluir la metodología y el procedimiento para el cálculo del déficit estructural, que es una cuestión que se deja abierta en el art. 135.2 CE. Finalmente, se debe incluir la responsabilidad de cada Administración Pública en caso de incumplimiento de los objetivos de estabilidad presupuestaria. En definitiva, un precepto que se podría haber redactado de forma breve, adopta una regulación extensa y de detalle, con la finalidad no de configurar las medidas concretas que se atribuyen a la Unión Europea, sino de fijar el marco para una futura regulación mediante Ley Orgánica, que constituye una de las novedades ampliar su ámbito material reservado a otro supuesto alejando la posibilidad de encontrar un hilo justificador de dicha reserva normativa.

Por último, el art. 135.6 CE establece que las Comunidades Autónomas adoptarán las disposiciones para la aplicación del principio de estabilidad y las decisiones presupuestarias, según sus Estatutos y dentro de los límites del art. 135 CE. Probablemente sea el precepto más superfluo de la Constitución, ya que viene a recordar que las CCAA deben cumplir este precepto y su Estatuto y, consecuentemente, adoptar las medidas y decisiones adecuadas para ello, cuestiones evidentemente reguladas en la Constitución y el Estatuto, por lo que este precepto viene a recordar que las normas se deben cumplir, sin aportar prescripciones distintas de las ya previstas en dichos actos normativos y en el ordenamiento jurídico.

Además de la regulación material, se debe tener en cuenta la disposición adicional de la reforma. Antes de entrar en su contenido se debe tener en cuenta que la reforma no contempla si se debe incluir entre las disposiciones adicionales de la Constitución o si se refiere a la reforma de la Constitución concreta sin pasar a formar parte del texto constitucional. En todo caso se trata de una cuestión formal, sin efectos en relación a su mandato, pero quizás hubiera sido conveniente suprimir alguna de las disposiciones adicionales de la CE que han perdido su eficacia como la cuarta y no dejarla en una zona formalmente ambigua. Entrando en su contenido, el párrafo primero establece que la Ley 
Orgánica prevista en el art. 135 CE se debe adoptar antes del 30 de junio de 2012. Este plazo en circunstancias normales parece ajustado dada la constitución de las nuevas Cortes en diciembre de 2011 y encontrarnos con el mes de enero fuera del periodo ordinario de sesiones, pero al tratarse de una Ley Orgánica de carácter prioritario se podrán superar las dificultades. El párrafo segundo es más sorprendente al incluir un mandato material mediante el cual se deben fijar en dicha ley los mecanismos que permitirán el cumplimiento de los límites de deuda pública, es decir, los procedimientos y reglas materiales, garantías o eventualmente las sanciones por incumplimiento de los límites o para dar la prioridad absoluta para satisfacer los créditos públicos. Seguramente hubiera sido más adecuado no regular este mandato en la disposición adicional, sino en el texto del precepto o en las propias previsiones del art. 135.5 CE. Finalmente, en el párrafo tercero se incluye una disposición sobre la entrada en vigor de los límites del déficit estructural, que se desvían hasta el año 2020, siguiendo en este caso las pautas marcadas por la disposición similar en la Ley Fundamental de Bonn. En todo caso, estos plazos indican que la urgencia de la reforma no estaba justificada, ya que se retrasa la entrada en vigor de las principales medidas en meses y en años.

Como se puede comprobar se trata de una reforma sobre un tema complejo, realizada sin un excesivo estudio técnico que contemplara su oportunidad y conveniencia. En definitiva, se trata de una reforma de carácter político que no ha utilizado un estudio técnico, pacto político amplio o acuerdo consensual con los actores no implicados en la iniciativa, lo que ha implicado una debilidad técnica en su contenido y dudas en su procedimiento de realización que analizaré en la siguiente cuestión.

\section{ALBERTO LÓPEZ BASAGUREN}

Hablar de la (im)pertinencia de la reforma del art. 135 de la Constitución puede ser un tanto atrevido, cuando las razones se sitúan, según parece, en la necesidad de calmar a los mercados de financiación de la deuda, a los que había que dar un mensaje para que confiasen en la voluntad - y en la capacidad - de España de controlar su endeudamiento. Por lo demás, parecía que se trataba de unas reglas que acabarían imponiéndose en el ámbito de la UE, de una u otra forma. Alemania estableció unas reglas en su Constitución - mediante la reforma de sus arts. 109, 109a, 115 y disposiciones complementarias - que parecía llamado a imponerse — de forma expresa o tácita- como regla en el seno de los países de la UE o, al menos, entre los miembros de la moneda única (Eurogrupo). Se trata, por tanto, de una cuestión de oportunidad política en la que tanto el qué como el cuándo dependen de razones políticas y económicas sobre las que se tiene escasa capacidad de incidir.

Es evidente que las Constituciones de los Estados miembros de la UE no son autónomas; y cuanto más débil es un país dentro de la UE menos autónoma es su capacidad constituyente. España, en estos momentos, es un país extremadamente débil, que está obligado a tratar de cumplir las exigencias que le imponen aquellos que, de una u otra forma, tienen capacidad de condicionar su estabilidad financiera — presente y futura-. En estas condiciones, sería muy atrevido por mi parte sostener que la reforma de la Constitución no era pertinente. 
Al margen de lo que diré al responder a la siguiente pregunta, creo que en esta pregunta me debo limitar al análisis del contenido de la nueva disposición constitucional. Y creo que para realizar ese análisis lo que procede es comparar nuestro nuevo artículo 135 con las disposiciones correspondientes de la Constitución alemana, incorporadas en la reforma de 2009. Sobre todo por una razón. Si Alemania consideró que era indispensable incorporar a la Constitución disposiciones que impusieran, en los presupuestos del Estado y de los Länder, límites al déficit y al recurso al endeudamiento en la determinación de los ingresos, si esa es la regla de quien impone sus criterios en la UE y si los mercados de financiación de la deuda las consideran necesarias, parece obligado analizar la reforma constitucional española por comparación al parámetro establecido en la Constitución alemana.

En este sentido, me parece que la reforma constitucional española es una declaración de (buena) voluntad que carece de algunos de los elementos más constringentes y precisos de la regulación constitucional alemana. Lo que, en mi opinión, supone un riesgo importante de que se piense que España quiere dar la imagen de querer hacer las cosas bien, pero sin imponerse exigencias demasiado estrictas. Es difícil saber qué efecto tuvo la reforma constitucional en la confianza sobre España, pero da la sensación de que, con ventaja sobre algunos otros países en riesgo, nuestro país está siempre salvándose de la caída, casi al límite, sin acabar nunca de eludir del todo el riesgo.

Los elementos que diferencian el contenido de la reforma constitucional española de la alemana son muy relevantes, en mi opinión, a los efectos que parecían pretenderse con la incorporación de la nueva disposición constitucional. La Constitución alemana establece directamente los límites del endeudamiento presupuestario, precisando que los presupuestos — que deben ser equilibrados, obviamente — no pueden contemplar ingresos procedentes de endeudamiento (créditos) (art. 109.1). La Constitución precisa más y establece que esta prohibición solo se entenderá cumplida si los ingresos provenientes de endeudamiento (créditos) no superan, en el caso del presupuesto de la Federación, 0,35 por ciento en proporción al producto interior bruto nominal, mientras que en el caso de los presupuestos de los Länder solo se entenderá cumplida si no se admiten ingresos provenientes de deuda (créditos); es decir, cero (art. 109.3). Estas limitaciones se encuadran en una perspectiva de «ciclo económico» — tanto la Federación como los Länder pueden tomar en consideración, «de forma simétrica en expansión y recesión», los efectos de un desarrollo coyuntural divergente de la situación normal- Y Y se prevén las excepciones de situaciones extraordinarias de emergencia (art. 109.3) — copiadas casi literalmente por la reforma española-.

Estas disposiciones se complementan con las establecidas en los arts. 109a y 115, que se refieren, respectivamente, a las «situaciones de crisis presupuestaria» y a los «límites del endeudamiento (créditos)», disposiciones que deberán desarrollarse por Ley federal. El primero de ellos establece un sistema de supervisión de la economía presupuestaria de la Federación y de los Länder, a través de un Consejo de Estabilidad (Stabilitätsrat), dirigido a evitar situaciones de crisis presupuestaria, a comprobar la existencia de una situación amenazante de crisis presupuestaria y a desarrollar los programas de saneamiento para evitarlas. El segundo establece que una ley federal determinará o permitirá determinar las cuantías de los créditos, así como fianzas u otras garantías, que pueden asumir la Federación y los Länder cuando pueden dar lugar a gastos en ejercicios económicos futuros. 
El nuevo art. 135 de nuestra Constitución quiere utilizar los mismos elementos que la reforma alemana de 2009. Quiere tocar la misma «música»; pero solo reproduce aquella melodía de forma superficial, de forma parcial. Faltan los elementos esenciales que identifican la reforma constitucional alemana; precisamente, los elementos más constrictivos: la fijación constitucional de límites insuperables de ingresos presupuestarios con cargo a endeudamiento — que es de cero para los Länder — y el establecimiento de un órgano de control del cumplimiento de las prescripciones constitucionales sobre endeudamiento presupuestario.

La reforma constitucional española, en efecto, establece el principio de la estabilidad presupuestaria y la prohibición — tanto para el Estado como para las Comunidades Autónomas- de incurrir en un «déficit estructural» que supere los márgenes establecidos por la UE. Pero la determinación de los límites del déficit estructural se remite a una Ley Orgánica, con lo que la decisión constituyente acaba quedando indeterminada. El nuevo art. 135 sí establece un elemento formal que tendría que convertirse en un instrumento determinante de control del endeudamiento futuro: tanto el Estado como las Comunidades Autónomas requerirán autorización legal — ¿ley del Estado? ¿Ley autonómica?; frente a la precisión alemana de que será una ley federal, la Constitución española lo silencia - para «emitir deuda pública o contraer crédito». Pero nos encontramos, nuevamente, ante un elemento que tendrá que concretarse en el futuro. Cuando el problema de un país es de credibilidad, las promesas sobre rigor futuro no suelen ser muy convincentes para quien pone en duda su credibilidad; sobre todo, cuando a su lado, otro país, de cuya credibilidad no dudan, asume compromisos concretos y constrictivos.

A partir de ahí, la reforma constitucional española vuelve a tratar de tocar la misma melodía que la alemana: los límites del déficit estructural entrarán en vigor a partir de 2020 y la Ley Orgánica que lo fije y que desarrolle las previsiones de la nueva disposición constitucional —especialmente, la distribución de los límites de déficit y de deuda entre las distintas Administraciones, la metodología y el procedimiento para el cálculo del déficit estructural y la responsabilidad de cada Administración en caso de incumplimiento- deberá estar aprobada antes de mediados de 2012.

En conclusión, no me siento capaz de poner en duda la necesidad de la reforma constitucional del art. 135. Pero creo que, dejando para la siguiente pregunta las cuestiones de procedimiento, el texto de la nueva disposición constitucional es más una muestra de la debilidad y la incapacidad de España que de su fortaleza y determinación de imponerse los límites al endeudamiento que parecen ser requisito de credibilidad en el mercado de la deuda y en el seno de la UE. Creo que es lo que, de forma más destacada, pone de relieve la comparación entre nuestra nueva disposición constitucional y las disposiciones incorporadas a la Constitución alemana.

\section{ANTONIO LÓPEZ PINA}

Una respuesta lógica debe invertir la secuencia de ambas preguntas.

7 / 8.1 Formalmente, el Presidente del Gobierno y el líder de la Oposición mayoritaria se han distinguido por mostrar a la luz del día, no ya su insensibilidad para la 
Constitución y para la tramitación de una reforma constitucional y su plena carencia de un proyecto español alternativo para el gobierno económico de la Unión Europea; sino tan siquiera talla para, frente a la Comisión Europea, el Canciller de Alemania, el Presidente de la República francesa y el Banco Central Europeo, mantener dignamente la posición de España.

Siempre me ha parecido ficticia la separación entre fondo y forma. En el caso de la reciente reforma constitucional, las vulneraciones formales han sido particularmente graves. 1) Desde la presentación de la reforma (26 agosto 2011) y su aprobación por el Senado (8 de septiembre) transcurren solamente trece días. Discurrido el plazo de quince días para solicitud de referendum (art. 167.3 CE), la reforma es publicada en el Boletín Oficial del Estado, entrando en vigor el mismo día (27 septiembre). 2) El Pleno del Congreso acuerda, tomar en consideración la Proposición de reforma, así como su tramitación por el procedimiento de urgencia y plazo de cuarenta y ocho horas para presentación de enmiendas, y en lectura única. 3) El Pleno del Congreso celebró sesión ordinaria para el debate y votación de la proposición de reforma constitucional (2 septiembre). Rechazadas todas las enmiendas, la Proposición de reforma es sometida a votación de conjunto. La aprobación por el Pleno del Congreso de los Diputados se publica en en el BOCG (6 septiembre). 4) En el Senado se abre (3 septiembre) un plazo de presentación de enmiendas de cuarenta y ocho horas. 5) La proposición se aprueba en Pleno (7 septiembre) 6) En los Boletines de Congreso y Senado se publica la apertura del plazo previsto en el art. $167 \mathrm{CE}$, dentro del cual una décima parte de los miembros de una u otra Cámara podían solicitar que, para la ratificación se sometiera a referendum la reforma aprobada por las Cortes (8 septiembre). 7) Concluído el plazo de quince días, el Rey sanciona la reforma constitucional, publicándose en el Boletín Oficial del Estado y entrando en vigor el mismo día (27 septiembre) — sin perjuicio de lo dispuesto en la disposición adicional única, apdo. 3, que entrarán a partir del año 2020 en vigor (27 septiembre $)^{13}$-.

El trámite de urgencia, la lectura única y la inadmisión de enmiendas no merecen mayor comentario.

7 / 8.2 En cuanto a la pertinencia y el sentido sustantivo de la reforma, el editor nos invita a adentrarnos en el terreno de la política presupuestaria, que no es el propio de un modesto constitucionalista. No obstante, acepto el envite, con la reserva de hablar sólo como ciudadano español de a pié, que paga religiosamente sus impuestos y vive la Constitución española bajo el postulado de la igual libertad de todos bajo el Derecho.

Entre el nuevo Pacto de Estabilidad, el Pacto de Competitividad, de marzo de 2011, el Pacto del Euro, de junio de 2011, y el Pacto del Euro +, a iniciativa del Gobierno, acordada con el Canciller Sra. Merkel y el líder de la Oposición mayoritaria, las Cortes han aprobado el principio de estabilidad presupuestaria, como reforma constitucional del art. $135 \mathrm{CE}^{14}$.

13 Agradezco la ilustradora lectura de La Reforma de 2011: de las musas al teatro, de BLANCO VALDÉS, R., Claves de Razón Práctica, no 216 y de Reforma constitucional e Integración europea, de TAJADURA, J., Claves de Razón práctica, $\mathrm{n}^{\circ} 216$, de las que estas consideraciones son particularmente tributarias.

14 Art. 135 CE. 1. Proclama el principio general de que todas las Administraciones Públicas adecuarán sus actuaciones al principio de estabilidad presupuestaria; 2. Dispone que el Estado y las Comunidades Autónomas no podrán incurrir en un déficit estructural máximo permitido al Estado y a las Comunidades Autó- 
Ignacio Gutiérrez ha hecho recientemente un análisis convincente de la reforma constitucional, digno de especial glosa. Expone así el constitucionalista de la UNED: El nuevo art. $135 \mathrm{CE}$, impuesto por el directorio europeo, «responde a una doctrina desacreditada por la crisis de 1929, toda vez que su aplicación llevó a Occidente a profundizar en la depresión». En lenguaje paladino, la pregunta formulada por el Sr. Alzaga significa: « ¿tiene sentido incorporar a la Constitución, una norma caracterizada por su estabilidad, un principio sometido a discusión y de alcance coyuntural?» Más aún: no resulta sino innecesario y redundante, convertir en norma constitucional un principio vigente y, como Derecho de la Unión, vinculante para los Estados-miembros. Por si alguna duda pudiera haber al respecto, «el nuevo art 135 CE fija, por remisión a los valores de referencia del Protocolo adicional no 12, al que reenvía el art. 126 del Tratado de Funcionamiento de la Unión Europea, los límites de deuda y déficit públicos».

La perplejidad del lector, al llegar aquí, es pertinente. La explicación del esperpento reside esta vez en la voluntad del Canciller, autoinvestido dictador — comisario para Europa, Sra. Merkel. En la Lissabon-Entscheidung, de 30 de junio de 2009, «el Bundesverfassungsgericht ha definido la autonomía presupuestaria del Bundestag esencial para la preservación de la democracia alemana. En el discurso constitucional alemán, las reglas o limitaciones de Derecho europeo sólo son asumibles, en la medida en que hayan sido incorporadas a la Ley Fundamental; en tal sentido, el único expediente para que el Derecho europeo pueda limitar efectivamente la competencia presupuestaria del Parlamento alemán fue incorporar aquél a los arts. 109, 109 a, 115 LF».

Buen conocedor de los procesos constitucionales y de la jurisprudencia alemanes, Ignacio Gutierrez considera que la Sra. Canciller se cura en salud, blindándose constitucionalmente frente a una posible apertura de expediente a Alemania por la Comisión Europea, por razón de haber infringido el Pacto Europeo de Estabilidad ${ }^{15}$. Ello es plausible. Pero creo que, en su caso, sólo sería una parte de la verdad.

nomas en relación con su PIB; y que las Entidades Locales deberán presentar equilibrio presupuestario; 3. El Estado y las Comunidades Autónomas habrán de estar autorizados por Ley para emitir deuda pública o contraer crédito y que los intereses y el capital de la deuda pública de las Administraciones se entenderán siempre incluidos en el estado de gastos de sus presupuestos. A esas prescripciones se añaden: que el pago de la deuda gozará de prioridad absoluta, y que el volumen de deuda pública de las Administraciones Públicas en relación con el PIB del Estado no podrá superar el valor de referencia establecido en el Tratado de Funcionamiento de la Unión Europea; 4. Fija las condiciones en que podrán superarse los límites de déficit estructural y de volumen de deuda pública; 5. Previene que una Ley orgánica desarrollará los principios a que se refiere el art. 135, así como la participación en los procedimientos respectivos, de los órganos de coordinación institucional entre las Administraciones Públicas en materia de política fiscal y financiera y que, en todo caso, regulará: a) la distribución de los límites de déficit y de deuda entre las distintas Administraciones Públicas, los supuestos excepcionales de superación de los mismos y la forma y plazo de corrección de las desviaciones que sobre uno y otro pudieran producirse; b) la metodología y el procedimiento para el cálculo del déficit estructural; y, c) la responsabilidad de cada Administración Pública en caso de incumplimiento de los objetivos de estabilidad presupuestaria. Y, finalmente, 6.Preceptúa que las Comunidades Autónomas adoptarán de acuerdo con sus respectivos Estatutos y dentro de los límites a que se refiere el art. 135 CE, las disposiciones que procedan para la aplicación efectiva del principio de estabilidad en sus normas y decisiones presupuestarias.

15 GUTIÉRREZ, I., La reforma de la Constitución, entre estabilidad presupuestaria y estabilidad constitucional, Conferencia, Centro Cultural Isabel de Farnesio, Centro Asociado Madrid — Sur de la UNED_ Ayuntamiento de Aranjuez, 19 diciembre 2011. 
En un reciente Discurso al Congreso del SPD, y, por ende, a la nación alemana y a Europa $^{16}$, el Canciller Helmut Schmidt hacía un vibrante análisis de la dramática historia de las relaciones entre Alemania y el continente, para concluir la necesidad para el Gobierno y la sociedad alemanas, por un lado, de practicar en sus iniciativas políticas la virtud de la continencia, por otro, de solidarizarse con el resto de Europa. Con la elocuente alocución del Canciller avanzamos un segundo tramo en nuestro acceso a la verdad.

Existe un tercer tramo, a mi parecer, además: a diferencia de las sociedades anglosajonas y francesa, Alemania tiene con la historia contemporánea de España la singular afinidad, de una probada incapacidad para resolver políticamente los problemas de cada fase histórica y generación —en 1815, 1848, 1870-1871, 1914-1918, 1933-1945—. Los resultados para el continente europeo, de la impotencia de la sociedad alemana para resolver políticamente sus problemas, están documentados en las crónicas. Ello explica su contínuo recurso, desde 1949, al Derecho, al Bundesverfassungsgericht y al Poder judicial para resolver problemas de naturaleza política ${ }^{17}$.

De paso, Gutierrez subraya las diferencias de la situación española. «No hay, en primer lugar, una larga historia de desequilibrios presupuestarios a la que enfrentarse, sino un recientísimo exceso de gasto, que además apenas aleja a España de los estándares de los países miembros de la Unión. En segundo lugar, la incorporación a la Constitución del límite de deuda se hace, sin haber determinado previamente quién asume las tareas públicas y cómo las financia; comenzar limitando el gasto supone un riesgo objetivo para la correcta prestación de los servicios públicos. En tercer lugar, como no existe una norma constitucional genérica que se refiera a los presupuestos, los fines y los límites de la integración en Europa, la incorporación del límite de gasto de la Unión Europea resulta descontextualizada; no es necesaria, porque tampoco existe una jurisprudencia constitucional que imponga la autonomía presupuestaria de las Cortes Generales españolas frente a la Unión Europea; y, además de innecesaria, resulta sesgada, porque convierte a la Unión Europea en una instancia de control financiero, olvidando la riqueza de implicaciones que supone la integración.

En definitiva: la norma alemana sobre el déficit y la deuda tiene, en su propio contexto, un sentido preciso y unos efectos determinados. Pero su inserción en un contexto constitucional distinto, no permite suponer que se produzcan efectos jurídicos similares. Siempre es problemático transplantar instituciones concretas a climas constitucionales diferentes; pero resulta imposible que se adapten cuando lo que se pretende es injertar un brote muy singular en una Constitución de una especie completamente diferente»

Adicionalmente, haré unas consideraciones sobre la pertinencia de constitucionalizar rigor monetario y el control del gasto público, el principio de estabilidad presupuestaria, decidido e impuesto al resto de Estados de la Eurozona por el ordo — liberal conservadurismo del Canciller $^{18}$. Las posiciones al respecto pueden diferir en mayor o

16 SCHMIDT, H., Rede «Deutschland in und mit Europa» an den SPD-Parteitag, Unser Kapital: Demokratie und Gerechtigkeit, Berlin, 4 diciembre 2011.

17 LÓPEZ PINA, A., La dogmática alemana, punto de partida de una Teoría del Derecho público. Prolegomena a la Edición española, en, BENDA, MAIHOFER, VOGEL, HESSE, HEYDE, Manual de Derecho constitucional, $2^{a}$ edición, Madrid: Marcial Pons Ediciones Jurídicas, 2001.

18 Cuanto aquí expongo es tributario de gratas conversaciones con José María Zufiaur, Josep Borrell y Joaquín Estefanía. Adicionalmente, el tema ha sido una y otra vez objeto de debate, en el Círculo Fernando de los 
menor parte: por ejemplo, en la Alemania de la gran coalición, a fines de los sesenta, el ministro de Hacienda Karl Schiller (SPD), llevó al Bundestag una Ley de Estabilidad, basada en el cuadrado mágico — baja inflación, mínimos de déficit presupuestario, crecimiento y pleno empleo ${ }^{19}$ - ; en el bien entendido de que se trataba de una Ley, no de una reforma constitucional. Recientemente, el Canciller Helmut Schmidt ha dicho que tanto el déficit como la deuda pública tienen sentido cuando su destino son inversiones; no, en cambio, para afrontar los gastos corrientes. Paul Kirchhof, uno de los grandes iuspublicistas europeos de este momento, considera que la democracia representativa está perdida, si el déficit y la deuda ponen aquélla en manos de un concurso de acreedores — léase, los mercados financieros y las agencias privadas de calificación-. En fin, entre nosotros, Josep Borrell ${ }^{20}$ desdeña la norma como meramente simbólica y sin particulares efectos en la política gubernamental.

El debate sobre el particular, me parece sesgado, bajo la prepotencia no sólo del Canciller, sino asimismo de la ideología conservadora dominante. En la polémica no se subrayan suficientemente, a mi juicio, unas cuantas evidencias:

1. Como nos es familiar, Alemania y Francia incumplieron, en su momento, el Pacto de Estabilidad y Crecimiento. Tampoco el Banco Central Europeo está, en su compra de bonos soberanos de Grecia, Irlanda, Portugal, Italia y España, ajustándose a sus competencias que, conforme al Tratado, se reducen al control de la inflación. No es lo mismo incorporar el principio a la Constitución que aprobar una Ley de estabilidad presupuestaria: el gobierno de Rodríguez Zapatero aprobó en su momento una Ley para la estabilidad a lo largo del ciclo económico, dejando indeterminado si el mismo se extiende a tres, cuatro, cinco años.

2. Prestigiosos economistas proponen que los gastos de inversión, cualesquiera sea, no sean computados como déficit. La estabilidad presupuestaria no es políticamente neutral: se argumenta que el déficit presupuestario es una hipoteca para las futuras generaciones, lo que, en parte, es cierto. Sin embargo, la falta de inversiones en educación, en sanidad, en medidas de cohesión social, condiciona aún más a las futuras generaciones. A la postre, la estabilidad presupuestaria y las inversiones deberán ser ponderadas y decididas en términos del principio de proporcionalidad - justo lo contrario del déficit del 0,35\% del PIB, definido como techo absoluto por la Ley Fundamental alemana- (art. $115 \mathrm{LF})^{21}$.

La llamada regla de oro de la estabilidad presupuestaria acaba siendo una coartada conservadora para recortar gastos sociales, particularmente grave en un ciclo económico de recesión, y bloquear políticas de protección o de empleo. Añádase, a la resistencia numantina de gobiernos conservadores o no-conservadores a reducir el déficit mediante recurso a una subida de los impuestos directos.

Rios, con Juan Antonio Barrio de Penagos, Antonio G. Santesmases, José Antonio Pérez Tapias, Manuel de la Rocha, Pedro Sabando, Antón Saracibar y Mario Salvatierra.

19 Sobre el cuadrado mágico, cfr. \& 2 de la Gesetz zur Förderung der Stabilität und des Wachstums der Wirtschaft vom 8.6.1967, BGBl. L pg. 182.

20 Josep BORRELL, J; MISSÉ, A, La Crisis del Euro. De Atenas a Madrid, Madrid: Turpial, 2012.

21 Cfr. Supuestos constitucionales y de Derecho Europeo de la Deuda soberana. Paul Kirchbof conversa con Antonio López Pina en este mismo número de la RTRC. 
3. No sin razón, se ha criticado como flaco favor a la democracia, que la llamada «regla de estabilidad presupuestaria», limita la discrecionalidad soberana del Parlamento y, por ende, de los gobiernos. Ello viene a abundar en la aberración institucional, impuesta por Alemania, de la falta de responsabilidad política y de control parlamentario del Banco Central Europeo — a diferencia, por ejemplo de la Reserva Federal norteamericana, responsable ante el Congreso de Estados Unidos-.

4. En fin, hay que ser escéptico respecto de que, en caso de necesidad, gobiernos y parlamentos vayan a decidir en conformidad con tal norma constitucional.

9. A la luz de la reciente reforma del artículo 135 del texto constitucional, ¿podría realizar una valoración sobre su pertinencia, sobre el contenido sustantivo y sobre la literalidad de la misma?

\section{ELOY GARCÍA LÓPEZ}

Me temo que en la anterior respuesta he anticipado mi criterio. Pero no obstante quisiera llamar la atención sobre un dato en relación con la reforma que ya ha sido puesto de manifiesto por otros reputados colegas que han opinado al efecto. Las dos únicas reformas de la Constitución que han llegado a buen puerto en treinta tres años de democracia, han venido dadas (no quiero emplear la expresión impuestas) desde fuera. Y eso tiene mucho que ver con la particular voluntad con que los españoles hemos acudido al llamado europeo desde la transición política.

Maquiavelo en la última carta que dirige a su querido hijo Hector, le da un conmovedor consejo: «Hector figiuolo mio, estudia, fa bene, impara, ché si tu ti aiuterai, ciascuno te aiuterá». Pues bien los españoles desde 1977, hemos visto en Europa el remedio de nuestros males, hemos querido integrarnos en la Unión para que Europa nos ayude a resolver nuestros problemas, los que nos considerábamos incapaces de afrontar por nuestros propios medios. Así fue cuando nos integramos en la entonces Comunidad Europea en medio de una crisis económica que arrastrábamos desde los tiempos de la Guerra del petróleo, y también fue así cuando nos integramos en el euro. Que otros resuelvan lo que nosotros no sabemos o no podemos, parecía ser nuestro propósito.

Sin embargo no es ése el proceder coherente con la idea de autogobierno democrático, ni con los postulados propios de la soberanía democrática, ni tampoco la filosofía que inspira el obrar de los grandes países que dominan la Unión. Para ellos Europa es una mezcla de interés nacional y compartido, propio y foráneo, que conviven en permanente tensión. Alemania, Francia, Italia y los demás países han ido a Europa para obtener beneficios, para construir una Unión favorable a sus intereses nacionales, no para ser gobernados desde fuera. Eso genera un conflicto entre el interés europeo y el nacional, pero ese conflicto es inherente a la Unión.

La Unión Europea es una realidad política que se explica bastante bien desde las categorías que Antonio La Pergola investigó en su tesis sobre los orígenes de la Unión americana. Europa es un mundo en tensión en dónde a nada que se descuide una nación puede ser sacrificada a los intereses de otras, y sin que medie explicación alguna. Muy pronto empezaremos a verlo. Y tendremos que formularnos preguntas como ¿Quién ha tomado en Europa las decisiones políticas en los últimos tiempos? ¿Quién es el respon- 
sable de la desbocada ampliación de la Unión Europea de estos años? ¿A qué debate de ideas responden nuestro actual modelo de gobierno Europeo? ¿Es legítimo el apoyo incondicional prestado por la Unión Europea a la cleptocracia que gobierna las antiguas naciones soviéticas? ¿Tiene sentido el papel que una Europa liderada desequilibradamente por Alemania ha desempeñado en la destrucción de Yugoeslavia y el actual propósito de todos sus girones o fragmentos estatales de agruparse ahora bajo la común bandera europea?

\section{JUAN CARLOS GAVARA DE CARA}

Las reformas constitucionales no deben ser el fruto de una improvisación o de una copia y más si se tiene en cuenta que responden a una materia compleja en la que se deben mesurar con cuidado las consecuencias que pueden tener en un futuro. En este sentido, las modificaciones o inclusiones de nuevos preceptos constitucionales deben ser el fruto de un debate público en el que se conozcan bien las diferentes posturas políticas sobre su contenido y un estudio técnico que pueda prever posibles problemas o incorrecciones en la redacción de los preceptos. Aunque formalmente sea correcto, esta reforma por lo menos ha sido maltratada procedimentalmente, su consideración como un caso de extraordinaria y urgente necesidad, criterio materialmente discutible en todo caso y cuestionable en la eficacia de su resultado, ha ocasionado que el tipo de discusión sea más próximo a un decreto-ley que a un diálogo sereno entre las fuerzas políticas y la sociedad propia de una solemne trascendencia constitucional.

La reforma del art. $135 \mathrm{CE}$ se ha tramitado por el procedimiento de lectura única, probablemente el más singular de los procedimientos extraordinarios, que se caracteriza porque se tramita directamente en los respectivos plenos del Congreso y del Senado limitando la discusión a dicho momento, sin necesidad de ponencia o comisión. Este procedimiento se utiliza cuando un proyecto o proposición de ley no puede ser objeto de enmienda ya que responde a una negociación extraparlamentaria o cuando la simplicidad de la formulación no requiere una discusión por su sencillez y elementalidad y puede ser aprobado tras un mero debate en el pleno. Ninguno de estos supuestos se ha planteado en esta reforma (no existe una negociación extraparlamentaria por lo menos explicitada, ni se trata de una reforma caracterizada por la simplicidad tal como se ha analizado), debiéndose tener en cuenta que el Tribunal Constitucional consideró que los supuestos de aplicación del procedimiento de lectura única eran tasados sin posibilidad de extensión a casos similares (STC 27/2000). No deja de ser curioso que en la anterior reforma constitucional de 1992 (art. 13.2 CE) se utilizará el mismo procedimiento, pero tras la consulta y posterior declaración del Tribunal Constitucional, es decir, la tramitación no fue tan urgente y dio tiempo a un debate social y jurídico con anterioridad a su tramitación parlamentaria, y el contenido de la reforma era sencillo y elemental (añadir la palabra «y pasivo» a un precepto como consecuencia de la firma del Tratado de Maastricht).

Las reglas procedimentales de la reforma constitucional adquieren una verdadera relevancia por cuanto que en democracia la legitimación recae sobre el procedimiento en la fijación de las reglas fundamentales y básicas de funcionamiento de un sistema político, hasta el punto que numerosas Constituciones han previsto un control de constituciona- 
lidad sobre el respeto de las reglas procedimentales de la reforma constitucional, aspecto que en nuestro sistema no está previsto expresamente en su control de la constitucionalidad por parte del Tribunal Constitucional, pero tampoco excluido por lo que se podría incluir mediante la reforma de la Ley Orgánica del Tribunal Constitucional o tal como he planteado mediante una reforma de la Constitución.

\section{ALBERTO LÓPEZ BASAGUREN}

En relación con el procedimiento seguido en la aprobación de la reforma del art. 135 de la Constitución hay que distinguir la vertiente estrictamente jurídica de la vertiente política.

En lo que se refiere a la vertiente jurídica no tengo dudas sobre la aplicabilidad del procedimiento del art. 167, tal y como ha confirmado el TC en el Auto 9/2012, de 13 de enero - aunque comparto las argumentaciones manifestadas en el voto particular del Magistrado Pérez Tremps, a las que se adhiere el Magistrado Ortega Álvarez, respecto a la necesidad de que la decisión, a la vista de la elaborada argumentación sobre el fondo que contiene el Auto, tendría que haberse tomado en una Sentencia-. Tengo más dudas —en el sentido manifestado por el Magistrado Ortega Álvarez en su voto particularsobre las demás cuestiones del procedimiento seguido en las Cámaras en la tramitación de la reforma (trámite de urgencia, procedimiento de lectura única). El procedimiento parlamentario de reforma constitucional no puede ser radicalmente distinto del procedimiento legislativo; pero la significación de la reforma constitucional no puede llevar a una aplicación in toto, de forma subsidiaria, del procedimiento legislativo ordinario, como consecuencia de la falta de previsiones expresas en el Reglamento de la Cámara. La reforma constitucional tiene tanta trascendencia que chirría la aplicación, en esos términos, de las previsiones contenidas en el procedimiento legislativo ordinario que se aplicaron en este procedimiento (urgencia y lectura única). Las Cámaras parlamentarias deben regular expresamente el procedimiento de elaboración de las propuestas de reforma constitucional; y deben hacerlo en unos términos que se correspondan a la transcendencia jurídica y política de la reforma constitucional.

Lo que sí me parece profundamente criticable es la vertiente política de la tramitación de la reforma. Se trata de una reforma que — si había que hacerla — se hace tarde y de forma precipitada, tratando de recuperar el tiempo perdido mientras se creía que no era necesaria. Y en la forma precipitada en que se hizo se careció de la más mínima deferencia democrática con los ciudadanos.

Alemania incorporó en 2009 las previsiones constitucionales que sirvieron de modelo a la reforma española. Y lo hizo tras un serio proceso de elaboración y debate con implicación de los distintos partidos, instancias institucionales y apoyo técnico. Cuando en 2006 Alemania aprueba la importante reforma constitucional del sistema federal, crea una Comisión que estudiará, durante tres años, la reforma constitucional sobre los criterios de endeudamiento.

Desde el punto de vista político, por tanto, tendríamos que preguntar, en primer lugar, qué se hizo en España al contemplar el camino emprendido por Alemania; más en concreto, qué hizo o qué consideró el Gobierno. ¿Se trataba de una obsesión alemana que 
a nosotros no nos afectaba? En segundo lugar, hay que analizar la actuación —en primer lugar, del Gobierno y, también, de la oposición - en el momento en que se llega al convencimiento de que es indispensable realizar una reforma constitucional como la del art. 135 y que, además, hay que hacerla de forma urgente y sin dilación, porque la estabilidad financiera de España corría un peligro inmediato.

Aceptando todos esos condicionantes, la gestión política de la reforma constitucional es inadmisible desde un punto de vista democrático. Se realiza una gestión directa, personal, por parte del Presidente del Gobierno con el líder del mayor partido de la oposición. El Presidente del Gobierno dio a conocer la propuesta cuando ya estaba acordada entre los dos líderes políticos sin que, parece, se hubiesen enterado, prácticamente, ni en sus propios partidos; y, sobre todo, sin que los ciudadanos se hubiesen enterado. En un sistema democrático a los ciudadanos se les puede pedir comprensión ante los sacrificios, ante medidas que haya que tomar, necesariamente, por duras que puedan ser. Pero no se les puede pedir que lo acepten sin explicarles los motivos con suficiente claridad. No se puede hacer una reforma constitucional de espaldas a los ciudadanos. Y los responsables políticos, empezando por el Presidente del Gobierno, tienen que asumir la responsabilidad de las propuestas que hacen, explicando a los ciudadanos porqué considera indispensable su adopción y, en este caso, porqué no se planteó antes; porqué el Gobierno no previó los problemas que se iban a plantear y porqué no supo adoptar a tiempo las medidas oportunas. Nada de esto hicieron el Sr. Zapatero y su Gobierno. No hubo explicación transparente ni suficiente debate como para que los ciudadanos pudiesen asumir la reforma, su necesidad y su contenido. Una peligrosa progresión hacia un sistema democrático cada vez más despótico, en el que los líderes políticos cada vez personalizan más las decisiones políticas.

Por eso decía más arriba que, en contra de lo que pueda parecer, las dos reformas constitucionales que se han realizado en España lejos de servir para «naturalizar» la reforma constitucional, facilitando la realización futura de otras reformas, confirman que las reformas constitucionales solo se pueden hacer en secreto, por acuerdo de quienes tienen sobre sus hombros la responsabilidad del Estado, de forma despótica, fuera del debate público y al margen de los ciudadanos, a sus espaldas.

\section{ANTONIO LÓPEZ PINA}

Contestado en la respuesta anterior 


\title{
LA CONSTITUCIONALIZACIÓN DE LA DEUDA SOBERANA. UN DIÁLOGO CON ANTONIO LÓPEZ PINA ${ }^{22}$
}

\author{
Paul KIRCHHOF \\ Catedrático de Derecho Público, Financiero y Presupuestario. Universidad de Heidelberg \\ Ex Magistrado del Tribunal Constitucional alemán
}

\section{CUESTIONES}

19. Muchos Estados de la Unión Europea y numerosas empresas importantes están fuertemente endeudados, sobre todo, frente al capital financiero. La crisis financiera lastra la Unión Europea y amenaza el euro. ¿Cuáles son, a su juicio, las causas de una evolución tan errática?

$2^{a}$. Desde el año 2008 estamos desdichadamente familiarizados con los problemas de la deuda soberana. A través de los medios, de oídas, los europeos nos hemos enterado de la reforma constitucional de la Ley Fundamental consagrada en el art. 115. Pero, hasta hoy, no bemos tenido la fortuna de cruzarnos con un interlocutor como usted, que pueda contarnos su contenido y explicarnos la razón última de la decisión del constituyente alemán. Más aún, ¿ hasta qué extremo comparte usted la tesis, de que una fórmula plasmada en Derecho con fuerza normativa es mejor, que confiar en la racionalidad de los gobiernos y de las mayorías parlamentarias?

$3^{a}$. El caso es que los Estados-miembros de la Unión Europea, y, en particular, de la Eurozona, no son sea una isla de la estabilidad, sea una excepción de inestabilidad. Justo por razón de la moneda común, los Estados de la Unión Monetaria están económico-financieramente ligados entre sí, hasta el extremo de que la evolución en uno u otro sentido de un país afecta a la totalidad de la Eurozona. Los Estados altamente endeudados presionan a la Unión, y a Alemania en concreto, en favor de una mancomunidad solidaria de todos los Estados; o, al menos, de promesas de garantía de los Estados solventes, que aporte una cierta seguridad político-financiera a los Estados endeudados y que haga bajar en los mercados los intereses del pago de la deuda. Háblenos, por favor, de en qué medida y hasta qué extremo, el Derecho Europeo vincula a los Estados para dar una respuesta proporcionada al déficit presupuestario y el endeudamiento

$4^{a}$ Me parece razonable la pretensión en la doctrina dominante, de que los Estados europeos deberian retornar a la Comunidad de Derecho que es la Unión y volver a observar estrictamente las normas vinculantes. Sin embargo, ello no ayuda a que los endeudados Estados salgan de su actual crítica situación. ¿Ofrece el Derecho Europeo norte para una transición desde la actual situación de necesidad a la normalidad político-financiera?

$$
* * *
$$

22 El Director y el Consejo de Redacción de la revista agradecen de forma muy particular la intervención de D. ANTONIO LÓPEZ PINA, Catedrático de Derecho Constitucional de la Universidad Complutense, en su condición de máximo especialista español en el Derecho constitucional alemán, a los efectos de que nuestra publicación pueda recoger en sus páginas los muy interesantes criterios del profesor PAUL KIRCHHOF sobre cuestiones de rabiosa actualidad e interés constitucional. Extendiéndose nuestro agradecimiento a que lo haya hecho en un género literario académico tan ameno como el de la entrevista de altura por él diseñada. 
$1^{a}$ Muchos Estados de la Unión Europea y numerosas empresas importantes están fuertemente endeudados, sobre todo, frente al capital financiero. La crisis financiera lastra la Unión Europea y amenaza el euro. ¿Cuáles son, a su juicio, las causas de una evolución tan errática?

\section{PAUL KIRCHHOF}

Los Estados y las sociedades europeos se han ido acostumbrando a vivir por encima de sus posibilidades. El Estado en libertad se financia no con sus propiedades y empresas públicas, sino mediante la participación en el éxito económico privado. El Estado en libertad garantiza libertad profesional y derecho a la propiedad privada, confía a la iniciativa privada los factores de la producción trabajo y capital; por tal razón, se ve obligado a financiarse mediante impuestos al trabajo y al capital. El Estado y, el Estado democrático en particular, quiere responder a los deseos de los ciudadanos. Y el hecho es que éstos demandan al Estado, simultáneamente, menos impuestos y cada vez mayores servicios y prestaciones. Ello explica que los Estados tiendan a buscar la salida a menos ingresos y a un mayor gasto en el endeudamiento público, que financie las tareas del presente mediante crédito, que la próxima generación habrá de devolver con intereses más los intereses de esos intereses. El contrato de préstamo es decidido por los gobiernos y aprobado por los parlamentos, a fin de privilegiar a los públicos actuales y hacer que las cargas recaigan sobre la siguiente generación. Nuestros hijos deberán financiar nuestra hodierna abundancia, sin a día de hoy poder defenderse en elecciones o en procesos judiciales.

Los mercados financieros, en particular los bancos y las compañías de seguros, ofrecen una y otra vez nuevos créditos al sobreendeudado Estado, como socio bienvenido. Las partes del contrato son conscientes, de que en el momento del vencimiento el Estado no cumplirá con sus obligaciones de pago, por más que pueda haber hecho hasta ahora religiosamente frente al pago de los intereses. Ello explica el continuo aumento de la deuda soberana. No es infrecuente, que la carga de los intereses sobre los intereses aumente en términos tales que, por alto que pueda llegar a ser el crecimiento económico, nunca se pueda llegar a saldar la deuda. La dependencia del Estado de los acreedores aumenta, el precio que paga el Estado se convierte en un precio político, que el Estado ha de mantener bajo, mediante concesiones políticas. Cuanto más se endeude el Estado, tanto más caerá en una situación de dependencia de los mercados financieros. Cuyos portavoces, las agencias de calificación, valoran la capacidad de crédito de los Estados y determinan, por ende, los intereses del Estado endeudado, decidiendo en último término sobre los márgenes de maniobra y la soberanía del Estado .

Los Estados son considerados, en general, inmunes a la insolvencia, dado que los contribuyentes harán frente a la deuda soberana. De todos modos, la experiencia histórica enseña — en particular, la del siglo XIX — que Estados europeos una y otra vez han caído en la insolvencia y que, no obstante, los mercados financieros les han otorgado nuevamente créditos; si bien, bajo condiciones tales que anticipan el riesgo de insolvencia por el valor de la propia solicitud de crédito. También, en la actualidad, Estados euro- 
peos al borde de la insolvencia y lastrados por rigurosos ajustes de saneamiento, se ven forzados a entregar completamente a los mercados financieros el juicio último sobre el éxito de sus programas de ahorro. Los ciudadanos ahorran en una medida como hasta este momento les era desconocida, sin poder participar en el éxito de tales programas de ahorro.

Pero también otros Estados, tenidos por financieramente sólidos, deben entregar a los mercados financieros una parte considerable de sus ingresos fiscales. De ese modo, se ve derogado el principio de igualdad del Derecho financiero, por el que se garantiza al contribuyente que se devolverá toda la recaudación fiscal a la generalidad de los contribuyentes. Si ciertamente el Estado fiscal recauda, es al fin de devolver los recursos a sus ciudadanos.

La crisis de los institutos financieros trae causa, sobre todo, de que, por razón de su carácter internacional, los mercados financieros no se dejan fácilmente regular. Por lo demás, en el curso de la desregulación, han sido derogadas normas que asignaban responsabilidad y consignaciones por sus errores a los actores financieros prestos a asumir riesgos. Eventualmente, se otorgan tales créditos a deudores, sin verificar previamente su fiabilidad. Muy pronto, tales créditos son vendidos con lucro a sociedades de fin determinado ${ }^{23}$, de forma que el éxito de la venta es contabilizado, sin que se tenga en cuenta la disposición y capacidad del deudor para devolver el dinero. De ese modo, se acaba organizando la irresponsabilidad. Lo propio sucede cuando se invierte en un fondo, sin saber si el rendimiento de las cantidades invertidas se debe a la producción de trigo o de armamento militar. Y cuando la conducta de los inversores cobra el carácter de juego y apuesta; cuando el apostante juega con la ruina de empresas o de Estados, es decir, cuando el apostante se lucra con la desdicha de los hombres, los mercados financieros pierden racionalidad, calculabilidad, honestidad. Mientras que en el mercado de mercancías y servicios, la escasez de dinero y de productos asegura la adecuación del intercambio entre vendedores y compradores, el dinero es en los actuales mercados financieros, macroeconómicamente, apenas un bien escaso; la contraprestación en el juego y en la apuesta, más que un palpable cambio de valores es expectativa, esperanza y temeridad.

2a. Desde el año 2008 estamos desdichadamente familiarizados con los problemas de la deuda soberana. A través de los medios, de oídas, los europeos nos hemos enterado de la reforma constitucional de la Ley Fundamental consagrada en el art. 115. Pero, hasta boy, no hemos tenido la fortuna de cruzarnos con un interlocutor como usted, que pueda contarnos su contenido y explicarnos la razón última de la decisión del constituyente alemán. Más aún, ¿ hasta qué extremo comparte usted la tesis, de que una fórmula plasmada en Derecho con fuerza normativa es mejor, que confiar en la racionalidad de los gobiernos y de las mayorías parlamentarias?

23 Zweckgesellschaften son empresas creadas con el fin de sacar determinados objetos patrimoniales (leasing, Asset nacked securities, fondos especiales, ...) del balance de la bolding - empresa madre o una operación de refinanciación. Una vez logrado el objeto, la empresa puede ser liquidada. 


\section{PAUL KIRCHHOF}

Todavía no hemos acabado de sacar las consecuencias de la experiencia de los últimos años. Los mercados financieros y muchos políticos presionan para continuar la política de beneficios para los actuales públicos a costa de nuestros hijos, y en no asumir una cultura de la ponderación para las finanzas. De todos modos, el legislador constituyente ha regulado, mediante la reforma federal del año $2009^{24}$, los supuestos constitucionales para el endeudamiento del Estado, prohibiéndolo básicamente.

La justicia requiere siempre una cultura de la medida apropiada. De ahí que las constituciones modernas consideren la desmesura y la arbitrariedad no conformes a Derecho. El Estado de la Hacienda tiene que contar cuidadosamente su gasto público y afinar sus tareas según la limitación de sus ingresos. Cuando un Estado gasta anualmente más dinero del que recauda, y trata de financiar sus necesidades actuales mediante crédito a costa de los futuros contribuyentes, tal endeudamiento es materia de la prohibición de desmesura. Bien se trata de una decisión inconstitucional o bien precisa de una especial justificación.

Y, sin embargo, la economía y el Estado actuales presionan a favor del crecimiento, y viendo en el crédito un instrumento para aumentar la productividad y el bienestar. Lo que sucede es, que los principios válidos para la economía privada y para el Estado son fundamentalmente diferentes. Mientras que la economía satisface la necesidad de mercancías y servicios de las personas, el Estado tiene como tareas garantizar la paz, la seguridad y el Derecho. La «productividad» del Estado no reside estructuralmente en prestaciones objetivas y servicios, sino en la organización de una comunidad pacífica bajo el Derecho, que garantice la libertad, la igualdad en términos de estatus social básico y en las posibilidades de despliegue de la persona, la seguridad en el desarrollo personal y en la vida pública.

El afán económico de lucro y la disposición parlamentario-democrática a cada vez más prestaciones del Estado conducen, a que aumente la cantidad de dinero líquido y se acelere la puesta del mismo en circulación, a que se vean desbordados los Presupuestos del Estado y a que el Estado caiga en el endeudamiento; en fin, a que peligre el valor del dinero. El sistema democrático debe moderar los impuestos, las tareas y el endeudamiento del Estado haciendo que el deudor fiscal — representado por sus Diputados- decida personalmente sobre impuestos, presupuestos y deuda pública. Sin embargo, la realidad democrática actual lleva a los diputados y a los candidatos a hacer más y más promesas adicionales de prestaciones públicas. Anticipan así programas adicionales de gasto, y, por ende, un aumento de los impuestos.

El endeudamiento del Estado se considera en sí mismo malo; tanto los financieros como los beneficiarios del Estado fiscal deben ser las mismas personas, y posteriormente como «pueblo soberano» deben recibir como «compensación» prestaciones estatales con cargo a los ingresos fiscales ${ }^{25}$. De todos modos, el tiempo nuevo subraya que la deu-

24 Gesetz zur Änderung des Grundgesetzes vom 29.07.2009, BGBl I 2248.

25 Cfr. BVerfGE 55, 274 (304) — tarea de formación profesional— en conexión con HATSCHEK, J., Deutsches und preussisches Staatsrecht, Band II, 2. Aufl. 1939, pg. 270 y sgs. Se concibe que los impuestos son independientes de una prestación pública compensatoria, MAYER, O., Deutsches Verwaltungsrecht, 3. Auflage 1924, 1. Band, pgs. 315 y sgs. (una tasa «sin condiciones»); VON GERLACH, H., Die Geschichte des preusischen Wablrechts, 1908, pg. 11; RICARDO, D., Untersuchungen über das Anleihesystem, en: DILE, K., MOMBERT, P., (Hrsg.), Das Staatsschuldenproblem, ((1820), 1980, pg. 94 (140). 
da soberana puede concordar las necesidades futuras al progreso de la Hacienda, financiar prometedores proyectos de futuro mediante cargas financieras al porvenir ${ }^{26}$; en tal sentido, un Estado sin deudas bien emprendería poco para su futuro, bien exige demasiado a su presente ${ }^{27}$. Las teorías modernas de la justicia declaran una ideada condición originaria de todas las generaciones que, bajo un «velo de la ignorancia», se entienden recíprocamente sobre un principio general de ahorro, de modo que cada generación recibe de sus predecesores la parte que en justicia le corresponde, $y$, por lo que a ella respecta, da a sus sucesores la parte justa a la que tienen derecho ${ }^{28}$.

Sin embargo, tal abstracción del interés personal no resulta posible al ser humano. Apenas si cobra el mismo suficiente madurez en el empleo responsable, cara al futuro, de los recursos financieros obtenidos mediante el endeudamiento del Estado. Todas las experiencias con ambiciosos proyectos de lujosa representación, de financiación de la guerra y de dispendiosas prestaciones públicas del Estado enseñan que «el gasto a crédito» no compensa ${ }^{29}$.

De ahí que una y otra vez las constituciones traten de limitar el empeño estatal en créditos a lo financieramente posible. Así, la toma de empréstitos por el Estado ha solido ir conectada a «una extraordinaria necesidad» ${ }^{30}$. A tenor del art. 87 WRV $^{31}$ sólo será legítimo disponer de medios financieros a crédito «en caso de extraordinaria necesidad» y, ordinariamente «sólo para fines publicitarios» ${ }^{32}$. La Ley Fundamental ha impostado tales parámetros constitucionales — para empezar apoyándose conscientemente en el art. 87 WRV_-; a renglón seguido, ha exigido una excepción para «medidas financieras preventivas de la Federación para el caso de oscilaciones de la coyuntura económica o para solventar una crisis económica general» ${ }^{33}$. El concepto de «gasto para fines publicitarios» ha sido extendido en el transcurso del tiempo, hasta mucho más allá de lo que en principio se concibió como «tareas rentables» ${ }^{34}$. Tampoco se ha acreditado la sustitución del

26 VON STEIN, L., Lehrbuch der Finanzwissenschaft, Band II, 4. Auflage, 1878, pgs. 340 y ss.

27 Cfr. También BVerfGE 79, 311 (353) - Staatsverschuldung; HÖFLING, W, Staatsschuldenrecht, 1993, pg. 100 ss.; Hermann PÜNDER, H, Staatsverschuldung, in: ISENSEE, J / KIRCHHOF, P (Hrsg.), Handbuch des Staatsrechts, Band V, 3. Aufl., 2007, \& 123, Rn. 2 ss.

28 John RAWLS, J, A Theory of Justice, 1971, pg. 284 ss.; sobre el particular, Stefan MÜCKL, S, «Auch in Verantwortung für die künftigen Generationen» - «Generationengerechtigkeit» und Verfassungsrecht, in: DEPENHEUER, O. / HEINTZEN, M. / JESTAEDT, M / SAXER, P. (Hrsg.), Staat im Wort. Festschrift für Josef Isenssee, 2007, S. 183 (184 ss.).

29 Ya en su tiempo HENSEL, A., Der Finanzausgleich im Bundesstaat in seiner staatsrechtlichen Bedeutung, 1922, pgs. 169 y ss.

30 \& 51 de la Constitución de la Paulskirche, HUBER, E.R. (Hrsg.), Dokumente zur Deutschen Verfassungsgeschichte, Band 1, 3. Aufl., 1978, pg. 380; lo propio es el caso de la Constitución del Deutscher Reich, de 1871, RGB1 1871, pgs. 63 y ss., sobre el particular, el Secretario de Estado de Política Interior, Graf von Posadowsky - Wehner, en la Sesión del Reichstag de 9 junio 1902, StB 5501B y de 12 de diciembre de 1905, StB 239 B.

31 Constitución de Weimar

32 MORITZ SAEMISCH, F.E, Das Staatsschuldenwesen, in: ANSCHÜTZ, G. (Hrsg.) Handbuch des deutschen Staatsrechts, Band 2, 1931, pgs. 435 (438); cfr. Asimismo el art. 73 de la Verfassung des Nordeutschen Bundes de 26 de Julio de 1887, GBl 1887, pg. 1.

33 El Diputado Ludwig Kroll en la Comisión permanente, 15. Sitzung de 2 de diciembre de 1948, en: Jahrbuch des öffentlichen Rechts der Gegenwart, N. F., Bd. 1 (1951), pg. 822.

34 Dictamen sobre el Begriff der öffentlichen Investitionen, erstattet vom Wissenschaftlichen Beirat beim Bundesministerium der Finanzen, 26.4.1980, Schriftenreihe des Bundesministeriums der Finanzen, Heft 29, pg. 17. 
«la cobertura tradicional del principio con referencia al objeto por una más moderna perspectiva concerniente a la situación ${ }^{35}$, ni se ha evidenciado como sostenible limitar las inversiones según la suma de los gastos en los Presupuestos. Tal instrumento de la política financiera no operó tampoco como prohibición constitucional de la desmesura, no cumplió los estrictos requisitos de la idoneidad, necesidad y suficiencia para la defensa de la economía frente a una perturbación de los equilibrios generales; más bien abrió las puertas a la desmesura.

La tesis de la conexión entre necesidad actual y la carga que supone $e^{36}$, debía impedir que mediante deuda pública el Estado traslade «sus precupaciones a un futuro en el tiempo» ${ }^{37}$; es decir, que financie los actuales Presupuestos a costa del futuro. Con la vinculación en los Presupuestos entre inversiones y crédito, la Ley Fundamental ha intentado establecer una justicia trascendente a las generaciones, que mediante una renuncia a consumo actual, en favor de una consunción futura de valores, traslade a la futura generación las ventajas de las inversiones actuales; por consiguiente, que es legítimo también recabar de aquella la co-financiación de inversiones ${ }^{38}$. Adicionalmente, la vinculación de las inversiones asegura que las actuales prestaciones públicas sean financiadas por los actuales contribuyentes, que son los beneficiarios directos de las mismas ${ }^{39}$.

Es equivocada la idea, de que, dado que la siguiente generación también va a beneficiarse de las actuales inversiones, debería financiarlas. Cada generación se esfuerza en mejorar su nivel de vida y en confiar a sus hijos los resultados de sus progresos —obras de arte, avances de la Ciencia, desarrollos tecnológicos, una mejor cultura política, más humanidad, apoyo familiar, procura de asistencia social—. Cada generación vive de las bases, de lo que generaciones precedentes han puesto en pié en el propio beneficio. Tal progreso, sin embargo, no tiene por qué ser financiado por la siguiente generación; más bien, ésta deberá hacer que se desarrolle en beneficio de la subsiguiente generación. La justicia actual presume como algo obvio, que la generación de los padres entregue su patrimonio a la generación de sus hijos. La pregunta de una compensación para tal legado, de una justicia de trueque no se plantea para la herencia, y tampoco debería ser anticipada vía crédito. Sin embargo, habrá que verificar si, para pagar intereses a los acreedores financieros, se puede recurrir a ingresos fiscales actuales; en particular, si es legítimo al Estado empeñarse para pagar intereses y amortizaciones de créditos anteriores.

35 objektgebundenen Deckungsgrundsatzes durch eine moderne situationsgebundene Betrachtungsweise Begründung des Regierungsentwurfs zur Änderung des Art. 115 durch das 20. Gesetz zur Änderung des Grundgesetzes vom 2. Mai 1969, BGB1. 1, 1969, pg. 357.

36 HENSEL, A a.a.O.,pg. 169.

37 HENSEL a.a.O., TERHALLE, F, Finanzwisenschaft, 1930, pgs. 538 y ss.

38 Cfr. PÜNDER, H, a. a. O., \& 123, Rn. 3 ss. M. N.; Sachverständigenrat zur Begutachtung der gesamtwirtschaftlichen Entwicklung, Staatsverschuldung wirksam begrenzen - Expertise im Auftrag des Bundesministeriums für Wirtschaft und Technologie, 2007, pg. 49 ss.; 74 ss.: investitionsabhängige Verschuldung als «Goldene Regel der Finanzpolitik».

39 PÜNDER a.a. O. Rn. 4; ISENSEE, J Schuldenbarriere für Legislative und Exekutive-zur Reichweite und Inbalt der Kreditkautelen des Grundgesetzes, in: WENDT, R / HÖFLING, W / KARPEN, U / OLDIGES, M (Hrsg.), Staat - Wirtschaft - Steuern. Festschrift für Karl - Heinz Friauf, 1996, pg. 705 (706); Paul Henseler, Verfassungsrechtliche Aspekte zujunftsbelastender Parlamentsentscheidungen, in: Archiv des öffentlichen Rechts (1983), pg. 489 (520 ss.); Sachverständigenrat a.a. O. pg. 41. 
La observación, fijada exclusivamente en la actualidad, de que una inversión financiada mediante crédito puede animar actualmente la coyuntura económica, es corta de miras, al no considerar que las amortizaciones e intereses de tal endeudamiento debilitarán la futura coyuntura económica. Sobre todo, la vinculación entre inversiones y créditos, del año $1969^{40}$, se vio debilitada por la excepción, de que «a fin de defendernos de una perturbación del macroequilibrio económico», los ingresos por crédito podrían superar el volumen de inversiones. Por esa puerta entró la magia ${ }^{41}$ en el Derecho, se forzó al Estado en la facultad competencial y en la responsabilidad, de crear, en caso de crisis económica, mediante gasto público adicional a crédito o vía desgravaciones fiscales, una demanda adicional, asegurar puestos de trabajo y hacer crecer el producto social bruto $^{42}$. La «contrarrevolución de la teoría monetaria» ${ }^{43}$ objeta, que el endeudamiento público hace subir los intereses; con lo cual hace que las inversiones privadas se retraigan; de ese modo, cuando no neutraliza, invierte los efectos de creación de empleo por medio de mayor gasto público o una bajada de los impuestos. Se argumenta a menudo que el Estado, en su condición de demandante de crédito, ofrece las mayores garantías, pero en la medida en que lo hace, impulsa a la banca, en su caso, a los mercados financieros a postergar las necesidades privadas de crédito. Además, la corriente internacional de capital provoca una revaluación de la moneda indígena. La fragilidad macroeconómica y una alta tasa de paro condicionados por los costes y las estructuras económicas ${ }^{44}$ no pueden ser solucionadas mediante estímulos de la demanda vía endeudamiento estatal. La actualidad enseña que la satisfacción por el Estado de tareas adicionales, financiadas a crédito, no crean demanda adicional, apenas si hacen crecer la tasa de ocupación laboral y aumentar el producto social bruto; antes bien, el endeudamiento público puede dar lugar a más altos intereses, a reprimir inversiones privadas y a impedir los esperados efectos vitalizadores. Una revaluación de la moneda propia, gracias a la llegada de capital, internacional empeora las posibilidades de exportación, y aumenta las importaciones ${ }^{45}$. La experiencia muestra que el endeudamiento estatal no se autofinancia; antes bien, seduce al dinero fácil que favorece a los electores actuales y recae sobre los contribuyentes de mañana, en este tiempo nuestro, incapaces de defenderse.

Ello explica que los arts. 109, 115 LF $^{46}$ limiten más rigurosamente los márgenes de la Federación para tomar dinero a crédito ${ }^{47}$. Conforme a los arts. 109.3.1, y 115.2.1 LF,

40 15. Gesetz zur Änderung des Grundgesetzes vom 8.6.1967 (BGBl. L pg. 581).

41 Zum «magischen Viereck» cfr. \& 2 des Gesetzes zur Förderung des Stabilität und des Wachstums der Wirtschaft vom 8. 6. 1967, BGBl. l pg. 182.

42 Sobre el particular, cfr. John Maynard Keynes, Vom Gelde, 1932; Sachverständigenrat a. a. O. , pgs 45 ss.; BVerfGE 79, 311 (331) - Staatsverschuldung; Hermann Pünder a. a. O., Rn 8 ss.; Markus HEINTZEN, M, Staatshaushalt, in: ISENSEE, J / KIRCHHOF, P (Hrsg.), Handbuch des Staatsrechts, Band V, 3. Auflage 2007, \& 120, Rn. 21.

43 FRIEDMAN, M, Die Gegenrevolution in der Geldtheorie (1970), in KALMBACH, P (Hrsg.), Der Neue Monetarismus, 1973, pg. 47 ss.

44 Cfr. En detalle, PÜNDER, H a.a.O., \& 123, Rn 9 ss.

45 Sobre tales cuestiones y su trasfondo teórico-económico PÜNDER, H, a. a. O., \& 123, Rn. 8 ss.

46 En la versión des la Gesetz zur Änderung des Grundgesetzes vom 29.7.2009, BGBl 2009 1, pg. 2248 (Föderalismusreform II).

47 Zur gemeinsamen Verpflichtung von Bund und Länder in den Verpflichtungen aus Rechtsakten der Europäischen Gemeinschaft aufgrund des Art. 104 EG, cfr. Art. 109.2 LF. Sobre el particular, REIMER, E, in: 
el equilibrio presupuestario es un mandato constitucional. Por primera vez en la historia del constitucionalismo alemán, el endeudamiento neto ${ }^{48}$ queda prohibido ${ }^{49}$. En situación de normalidad, es legítimo un nuevo endeudamiento neto hasta un máximo de 0,35\% del producto interior bruto nominal (art. 115.2.3 LF). Tal tipificación de un nivel mínimo de inversiones de futuro ${ }^{50}$ permite una continente desviación de la prohibición de nuevo endeudamiento ${ }^{51}$. La Constitución parte de un endeudamiento estatal básico — desde ahora considerablemente reducido ${ }^{52}$ - En una fase coyuntural que se desvíe de la normalidad, habrá adicionalmente que «considerar simétricamente los efectos en los Presupuestos de las fases alcista y bajista de la coyuntura económica» —una prescripción que requiere una disciplina presupuestaria en función de la coyuntura, pero que cabe asimismo entender como un techo de endeudamiento ampliado ${ }^{3}$ - . En cualquier caso, los cargos que superen el umbral del 1,5\% del producto interior bruto nominal, deberán ser compensados conforme a la coyuntura económica (art. 115.2.4 LF). Habrán de ser anotados en una cuenta aparte a efectos de control. Finalmente, en caso de catástrofes naturales y situaciones extraordinarias de necesidad no controlables por el Estado, el art. 115.2.6 LF permite, con una mayoría cualificada de los Diputados del Bundestag, superar tales límites de crédito. Tal resolución deberá ir unida a un plan de amortización. Los créditos así contraídos, deberán ser devueltos en un tiempo prudencial.

El mandato constitucional del equilibrio presupuestario, una excepción cuantitativamente limitada de un nuevo endeudamiento neto y la obligación —asimismo cuantificada - de devolver la deuda pública prometen un considerable progreso de consolidación. Los criterios convencionales de una necesidad extraordinaria, de la vinculación de las inversiones, de una reserva de coyuntura y de una reserva de ley no han sido eficaces, porque siempre acaba siendo más fuerte la presión para financiar tareas actuales a costa de los contribuyentes del futuro. Ahora bien, si conforme al Derecho europeo ${ }^{54}$, la Constitución alemana opta por expresar cuantitativamente el parámetro constitucional, este Derecho

EPPING, V / HILlGRUBER, Ch, Grundgesetz, Kommentar, 2009, Art. 2009, Art. 109 Rn. 26 ss., dort Rn. $49 \mathrm{ff}$. insbesondere auch zur Verpflichtung der Gemeinden.

$48 \mathrm{Zu}$ Ermittlung der strukturellen Nettoneuverschuldungsgrenze in Art. 115 Absatz 2 Satz 2 GG durch das Statistische Bundesamt cfr. KUBE, H, in: MAUNZ, T / DÜRIG, G, Grundgesetz, Kommentar, Art. 115 (Stand: Oktober 2009), Rn. 147.

49 SEILER, Ch, Konsolidierung der Staatsfinanzen mithilfe der neuen Schuldenregeln, Juristen Zeitung 2009, pg. 721 ss.; KUBE, H in: MAUNZ, Th / DÜRIG, G a.a. O. (Stand: Oktober 2009), Art. 115 Rn. 3 ss.; zur zeitlichen Anwendbarkeit vgl. Art. 143d Abs. 1 GG, dazu LENZ, Ch. / BURGBACHER, E, Die neue Schuldenbremse im Grundgesetz, Neue Juristische Wochenschrift 2009, pg. 2561 (2565).

50 Cfr. SEILER, Juristen Zeitung 2009, pg. 721 (723), REIMER a.a.O. Art. 115 Rn.32; LENZ / BURGBACHER Neue Juristische Wochenschrift 2009, pg. 2561 (2562); KUBE a.a.O. Art. 115 Rn. 138.

51 CORIOTH, S, Das neue Staatsschuldenrecht - Zur zweiten Stufe der Föderalismusreform, Juristen Zeitung 2009, pg. 729 ss.; Kube a.a.O. Art. 115 Rn. 136

52 Sobre el particular cfr. GANDENBERGER, O, Öffentlicher Kredit und Einkommensverteilung, FinArchV Neue Folge, Band 29, 1970, og. 1 ss.; Dieter Duwendag, Staatsverschuldung - Notwendigkeit und Gefahren, 1983; Kube a.a.O. Art. 115 Rn. 139.

53 Así, KUBE a.a.O. Art. 115 Rn 3.

54 Art. 126 Abs. 2 EG, Entschliessung des Europäischen Rates über die Stabilitäts-und Wachstumspakt vom 17.6.1997, ABl. EG 1997, No. C 236, S. 1: Jährliche Kreditaufnahme bis zu 3 \% des Bruttoinlandsprodukts, öffentliche Schuldenstand bis zu $60 \%$ des Bruttoinlandsprodukts; dazu Ulrich Palm, Preisstabilität in der Europäischen Wirtschafts-und Währungsunion, 2000, pg. 46 ss. 
puede incidir, más precisa y rigurosamente que mediante determinaciones materiales, en los numéricos Presupuestos y Derecho financiero. Unida a un sistema preventivo de alarma (art. 109 a LF), esta barrera al endeudamiento puede estimular a nuevos planteamientos sobre el contrato generacional en materia de deuda pública.

3a. El caso es que los Estados-miembros de la Unión Europea, y, en particular, de la Eurozona, no son sea una isla de la estabilidad, sea una excepción de inestabilidad. Justo por razón de la moneda común, los Estados de la Unión Monetaria están económico-financieramente ligados entre sí, hasta el extremo de que la evolución en uno u otro sentido de un país afecta a la totalidad de la Eurozona. Los Estados altamente endeudados presionan a la Unión, y a Alemania en concreto, en favor de una mancomunidad solidaria de todos los Estados; 0, al menos, de promesas de garantía de los Estados solventes, que aporte una cierta seguridad político-financiera a los Estados endeudados y que haga bajar en los mercados los intereses del pago de la deuda. Háblenos, por favor, de en qué medida y hasta qué extremo, el Derecho Europeo vincula a los Estados para dar una respuesta proporcionada al déficit presupuestario y el endeudamiento

\section{PAUL KIRCHHOF}

Un endeudamiento de la magnitud actual atenta también contra el Derecho Europeo. Si los miembros de la Eurozona hubieran observado el Derecho Europeo en vigor, no se habría producido la actual crisis financiera. Según el art. 126.1 TFUE los Estadosmiembros evitan incurrir en déficit públicos desproporcionados. A fin de garantizar una cierta disciplina fiscal y mantener la autonomía presupuestaria de los Estados-miembros, el Tratado de Mastrique impuso la obligación jurídica de evitar déficits públicos desmesurados $^{55}$. Se da un déficit público desbordado cuando se ve amenazada la continua financiación de los Presupuestos o se lleva a cabo una política presupuestaria expansiva atentatoria contra la estabilidad ${ }^{56}$. Si se da o no el caso, habrá que juzgarlo observando la completa situación presupuestaria y económica ${ }^{57}$. Según art. 126.2.2 TFUE se examinará la observancia de la disciplina presupuestaria atendiendo a los dos criterios siguientes: el déficit público y la deuda pública. A tenor del art. 1 del protocolo $\left(n^{\circ} 12\right)$ sobre el procedimiento, que conforme al art. 51 TUE forma parte integrante de los Tratados, tales valores de referencia del art. 126.2 TFUE son: 3\%, para la relación entre el déficit previsto o el déficit real y el producto interior bruto, a precios de mercado, $60 \%$, para la relación entre la deuda pública y el producto interior bruto, a precio de mercado.

El art. 126.1 TFUE funda una auténtica obligación jurídica ${ }^{58}$. Tales «valores de referencia» determinan la «valoración global» del Consejo, a tenor del art. 126.6 TFUE, de

55 BANDILLA, in: GRABITZ / HILF, Das Recht der Europäischen Union - Kommentar, 2007, Art. 104 EGV, Rn 1.

56 HATTENBERGER, in: SCHWARZE, EU - Kommentar, 2008, Art. 104 EGV, Rn. 17

57 KHAN, in: GEIGER / KAHN / KOTZUR, EUV / AEUV, Kommentar, 2010, Art. 126 AEUV, Rn. 7

58 Allgemeine Ansicht, cfr. STREINZ / OHLER / HERRMANN, Totgesagte leben länger-oder doch nicht?; Der Stabilitäts-und Wachstumspakt nach dem Beschluss des Rates vom 25. November 2004 über das Ruhen 
la que resultan las sanciones ${ }^{59}$ por un déficit excesivo. En tal contexto, deberá específicamente verificarse, si una vulneración de los valores de referencia hace aumentar contínuamente la deuda estatal o bien, si los datos provisionales permiten avizorar que tal país está en camino de reducir su deuda.

El Consejo de ministros de Economía y Hacienda (ECOFIN) es competente para el juicio definitivo sobre la situación presupuestaria y de endeudamiento del Estado de que se trate. Con ello, se materializan los límites de Derecho Europeo al endeudamiento de los Estados. La puesta en práctica de tales barreras sufre, sin embargo, de un procedimiento que hace jueces del endeudamiento a los responsables del mismo, que enaltece como veladores del Derecho Europeo a quiénes lo vulneran. De ahí que se prevea una sanción, decidida por el sujeto que forma parte del mismo gremio que objeta, que no es de esperar en un procedimiento político.

Muchos Estados-miembros - Alemania, entre ellos — han transgredido una y otra vez los límites de endeudamiento, en particular las barreras a la deuda global. Tales prácticas son atentatorias contra el Derecho europeo. La naturaleza de la Unión Europea como Comunidad de Derecho ${ }^{60}$ requiere, acabar inmediatamente con tales infracciones jurídicas; es decir, abstenerse de un nuevo endeudamiento contrario al Derecho Europeo y reducir la deuda pública que rebase los límites establecidos.

El art. 125.1 TFUE asegura el comportamiento presupuestario correcto de cada Estado-miembro, en la medida en que se opone ya a la apariencia, de que otros Estadosmiembros o la Unión intervendrían a favor de un Estado con problemas presupuestarios. En casos de debilidades presupuestarias que hagan temer a los Estados - miembros las reacciones de rigor de los mercados financieros — en particular, una subida de los tipos de interés, y no, en vez de ello, esperar un alza general, si bien entonces menor, de los tipos de interés ${ }^{61}$ - . De ahí que el art. 125.1 TFUE contenga una exclusión general de responsabilidad por la Unión o los Estados-miembros, de aplicación inmediata ${ }^{62}$. Ni la Unión ni los restantes Estados-miembros han de hacerse corresponsables o subrogarse en las deudas de otro Estado miembro. Los términos «responsabilizarse» y «subrogarse» del Tratado excluyen todas las formas de aval para las obligaciones de otro Estado miembro. Excluyen una obligación de responsabilidad, pero comprenden también un aval voluntario para obligaciones ajenas ${ }^{63}$. Se excluye créditos, garantías y otros compromisos de efecto similar. El rigor de tal exclusión de tales responsabilidades y garantías se ve reforzado por el art. 125.1.3 TFUE que, excepcionalmente, prevé garantías financieras recíprocas, pero limitándolas a proyectos comunes ${ }^{64}$.

der Defizitverfahren gegen Frankreich und Deutschland, Neue Juristische Wochenschrift 2004, pg. 1553 (1554) n. w. N.

59 Sobre el particular, HÄDE, in: CALLIES / RUFFERT, EUV / AEUV, Kommentar, 4. Aufl., 2011, Art. 126 AEUV, Rn. 53 ss.

60 Zu diesem Begriff cfr. EUGH, Rs, 294/83, Slg.1986, 1339 (Le Verts) und G/91, Slg. 1991, 1 - 6079; cfr. También HALLSTEIN, Die EG, 1979, pg. 51 ss.; ZULEEG, Der rechtliche Zusammenhalt der EU, 2004, pg. 135 ss.; CALLIES, in: Ders. / RUPPERT, EUV / AEUV, Kommentar, 4. Aufl. 2011, Art. 2 EUV, Rn. 25.

61 HÄDE, a.a.O., Art. 125 AEUV, Rn. 1.

62 BANDILLA, a.a.O., Art 103 EGV, Rn. 2; HATTENBERGER, a.a.O., Art. 103, Rn. 1; HÄDE, a.a.O., Art. 125 AEUV, Rn.2

63 Ḧ̈DE, a.a.O., Rn. 3.

64 Cfr., GNAN, in: GRABITZ / HILF, a.a.O., Art. 103 EG, Rn. 22 ss.; Häde, a.a.O., Art. 125, Rn. 3. 
Actualmente, los «fondos de rescate» y garantías vulneran esta prohibición de responsabilidad y de promesas de garantía del Tratado. La Unión está en el mejor camino de hacer de la ilegalidad una fórmula de solución para los problemas, en vez de aportar una idea legal del saneamiento. De este modo, se hace de los fondos de rescate contrarios al Tratado la base de negociación de más y más créditos. Los contratos de crédito resultantes se ven aspirados en la turbina de una vulneración sistemática del Derecho.

La Unión Monetaria Europea tiene que retornar a los principios de una Comunidad de Derecho. Un endeudamiento del Estado sólo cabe legítimamente, para el déficit, en un $3 \%$ y, para la deuda soberana, en un $60 \%$ del producto interior bruto. Las transgresiones de la regulación del déficit y de la deuda del Derecho Europeo deben ser encauzadas mediante un plan plurianual fiable. Por principio cada Estado, en cuanto unidad democrática de su pueblo, es responsable de la observancia del Derecho y del saneamiento de sus finanzas.

4a. Me parece razonable la pretensión en la doctrina dominante, de que los Estados europeos deberían retornar a la Comunidad de Derecho que es la Unión y volver a observar estrictamente las normas vinculantes. Sin embargo, ello no ayuda a que los endeudados Estados salgan de su actual critica situación. ¿Ofrece el Derecho Europeo norte para una transición desde la actual situación de necesidad a la normalidad político-financiera?

\section{PAUL KIRCHHOF}

Es hora de volver al principio cristiano del viaje por mar: todo capitán de barco sabe que si hace encallar su barco, deberá ser el último en abandonar el buque que se hunde. Precisamente, porque el capitán asume un riesgo personal en su empeño, conduce su navío cuidadosa y perspicazmente por todos los mares.

Sobre tal base deberá el legislador mejorar las condiciones-marco del mercado financiero. Durante largo tiempo las sociedades de fin determinado ${ }^{65}$ estaban prohibidas. Los fondos podrían ser hechos transparentes siempre que cada inversor suscriba, si desea lucrarse negociando con trigo o con armamento militar. Responsabilidades jurídicas posteriores podrían conectarse a la firma del inversor. La banca universal debe ser compartimentada, de modo que la responsabilidad para el juego y para la apuesta no afecte al ahorrador que evita el riesgo; habría que separar ahorro, inversiones, bancos de inversiones, inversiones con capital propio en empresas no cotizantes en Bolsa ${ }^{66}$, juego y apuestas bajo la rúbrica de la banca universal en mutuas autónomas de responsabilidad.

Un impuesto de transacciones financieras podría responsabilizar fiscalmente a los actores de los mercados financieros, tendría como efecto ralentizar los movimientos de los mercados, impediría las reacciones de mercado dictadas por ordenadores — sin voluntad humana alguna de contrato-, a fin de moderar el componente especulativo de los mercados financieros. Lo ideal sería que el Derecho internacional pudiera establecer un Derecho de la competencia que relajara la retificación de los bancos, de modo que cada

65 Zweckgesellschaften vid. n.p.p. 7.

66 Private equity, inversiones en la financiación con capital propio de empresas no cotizantes en Bolsa 
cual fuera responsable de su conducta, y los holdings con «riesgos sistémicos» no pudieran recapitalizarse con cargo a los Presupuestos Generales del Estado.

Los Estados deberían ayudar a empresas amenazadas y también a otros Estados aunque siempre en relación de reciprocidad-. Cuando un Estado endeudado salva a un banco, tal banco una vez puesto a flote debería poner a disposición del Estado salvador una quita de la deuda, y, en particular, una condonación de intereses. Y los ciudadanos en cada Estado deberían constituir una suerte de mutua de ahorro. Ello podría traducirse en una regla jurídica, conforme a la que, cuando un Estado se endeudara en un $1 \%$ de más, todas las prestaciones estatales — del sueldo de un funcionario vía la subvención a la industria hasta la asistencia social— se redujeran consiguientemente en un 1\%. A partir del momento en que la deuda soberana no fuera por más tiempo un parámetro abstracto en los Presupuestos, sino que se hiciera notar en el bolsillo de cada ciudadano, es decir, cuando se realizara en cada uno la carga para el futuro, resultaría una ponderada comunidad de ahorradores de la alegre comunidad de endeudados. También de esa forma podríamos organizar el crecimiento económico. Un retroceso del crecimiento sería, sin embargo, defendible como precio de la consolidación económica, de la recuperación de la libertad individual y de la soberanía democrática.

\section{$* * *$}

TITLE: Academic Survey about Constitutional Reform

ABSTRACT: In this Academic Survey a group of Constitutional Law Professors answer some questions about constitutional reform, and particularly about the regulation of Constitutional Reform in Spain, the practice of this constitutional reform, the constitutional matters that should be amended or modified, and, of course, about the last constitutional reform of art. 135 CE (the content of the reform and also the special reform procedure).

RESUMEN: En esta encuesta un grupo de Catedráticos de Derecho Constitucional responden a un conjunto de preguntas sobre la reforma constitucional: sobre las normas que rigen la reforma de la Constitución Española de 1978, sobre la práctica de dichas normas, sobre las materias constitucionales que sería necesario reformar, y, en particular, sobre la reforma introducida en el art. 135 CE en 2011, tanto respecto al procedimiento seguido para la misma, como a su contenido. bility.

Key Words: Constitution, Constitutional Reform, Constitutional Reform Procedures, Reform and Budget Sta-

Palabras Clave: Constitución, Reforma constitucional, procedimientos de reforma, reforma y estabilidad presupuestaria. 